Portland State University

PDXScholar

\title{
A Validation Study of Components Necessary for the Professional Development of School Business Officials
}

William Henry Dierdorff III

Portland State University

Follow this and additional works at: https://pdxscholar.library.pdx.edu/open_access_etds Let us know how access to this document benefits you.

Recommended Citation

Dierdorff, William Henry III, "A Validation Study of Components Necessary for the Professional Development of School Business Officials" (1993). Dissertations and Theses. Paper 1197. https://doi.org/10.15760/etd.1196

This Dissertation is brought to you for free and open access. It has been accepted for inclusion in Dissertations and Theses by an authorized administrator of PDXScholar. Please contact us if we can make this document more accessible: pdxscholar@pdx.edu. 


\section{A VALIDATION STUDY OF COMPONENTS NECESSARY FOR \\ THE PROFESSIONAL DEVELOPMENT OF SCHOOL BUSINESS OFFICIALS}

by

WILLIAM HENRY DIERDORFF III

A dissertation submitted in partial fulfillment of

the requirements for the degree of

DOCTOR OF EDUCATION

in

EDUCATIONAL LEADERSHIP

Portland State University

1993 


\section{TO THE OFFICE OF GRADUATE STUDIES:}

The members of the Committee approve the dissertation of William Henry Dierdorff III presented February 8, 1993.

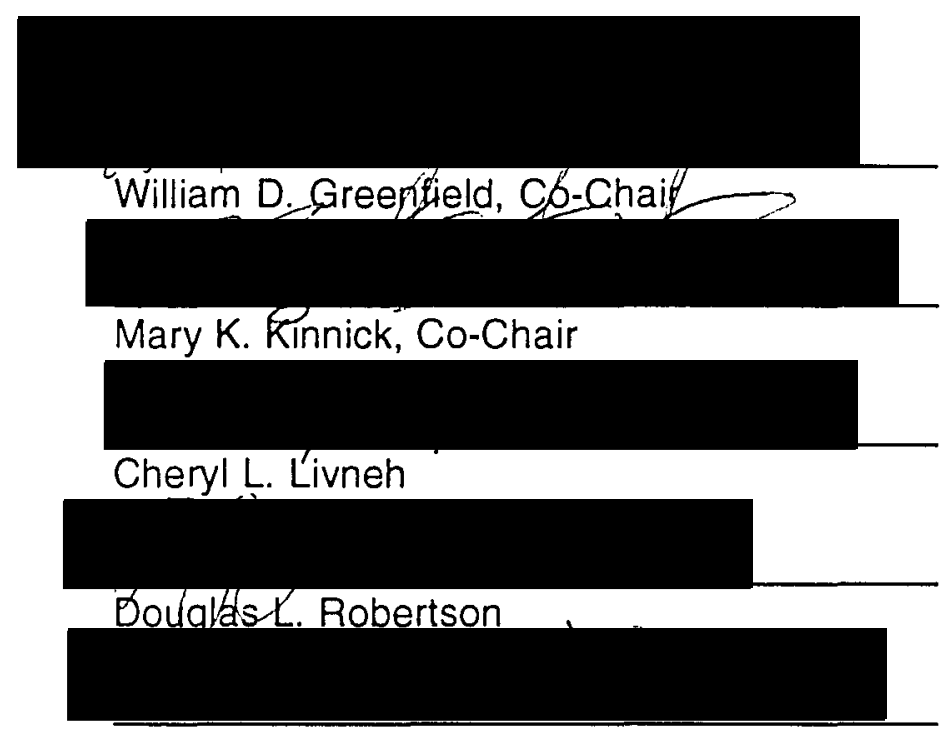

Dean E. Frost

APPROVED:

Robert B. Everhart, Dean, School of Education

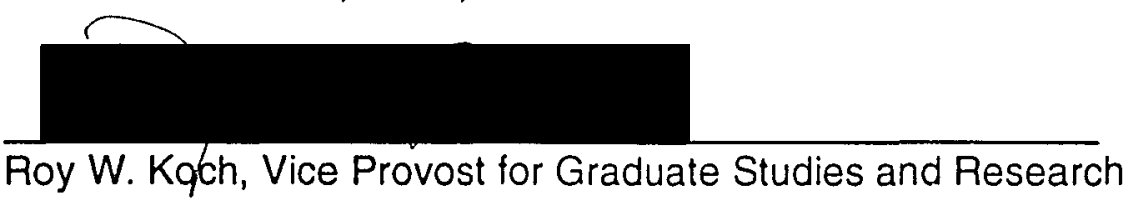


AN ABSTRACT OF THE DISSERTATION OF William Henry Dierdorff III for the Doctor of Education in Educational Leadership presented February 8, 1993.

Title: A Validation Study of Components Necessary for the Professional Development of School Business Officials.

APPROVED BY MEMBERS OF THE DISSERTATION COMMITTEE:

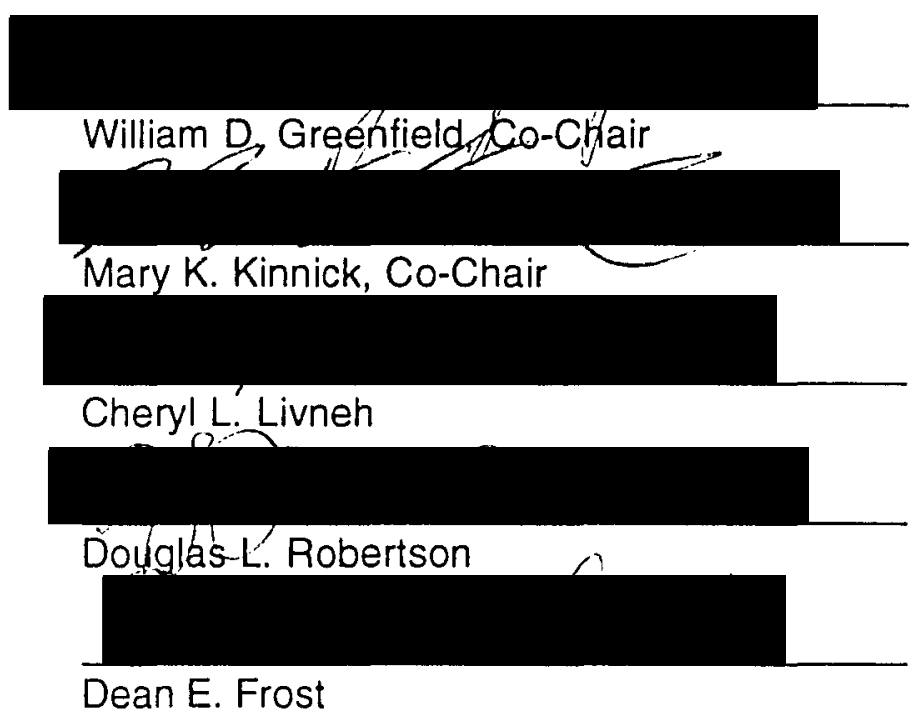

A key element of a profession is a formalized training program. School business officials in the United States and Canada face dynamic and complex issues without a standardized training program.

This study surveyed a representative group to validate a curriculum model developed by a 1988 task force funded by the Danforth Foundation. Another objective was to increase awareness of the need for an effective 
training program for school business officials and the most appropriate sources to implement that.

As indicated in the analysis, all components of the ASBO/Danforth model were considered important to the parties surveyed. There was no single preferred source of training, but rather, a preference for a variety of sources. Finally, there is general agreement in the perceptions of those surveyed, regardless of roles or demographic distinctions. This presents strong evidence for a common body of knowledge and a consensus for the sources of professional training to gain that knowledge.

As a result, recommendations for developing effective professional development for school business officials are presented both in general and by specific interest group. 


\section{DEDICATION}

This document is dedicated to my parents

\section{WILLIAM HENRY DIERDORFF \\ and \\ PATTY LOMAX DIERDORFF}

whose love and support for life, family, and education programmed me for whatever I will be. 


\section{ACKNOWLEDGEMENTS}

The completion of this dissertation reflects the support of many people. A special note of love and appreciation is due my wife, Susan, and my children, Scott, Amy, Mandy, and Tiggy, for sharing my goals and time.

I also extend my sincere appreciation to coworker Joline Shroyer, whose editing and coaching guided me through these many pages, and to superintendents Hauton Lee and Ben Schellenberg, who supported and mentored my graduate program.

Three key Portland State University educators, Bill Greenfield, Mary Kinnick, and Kathy Westbrook, welcomed me as part of the educational community and allowed me to direct my efforts in school business under the overall concepts of educational leadership. Additional support and encouragement was provided by committee members Cheryl Livneh, Doug Robertson, and Dean Frost. Gary Nave provided much-needed guidance through the statistical stages.

ASBO International staff encouraged my involvement in professional development for school business officials, included me in the ASBO/Danforth Task Force, and supplied mailing labels and financial support for the survey.

To all these people, I am grateful. 
TABLE OF CONTENTS

PAGE

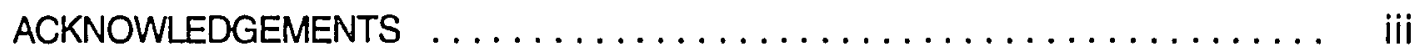

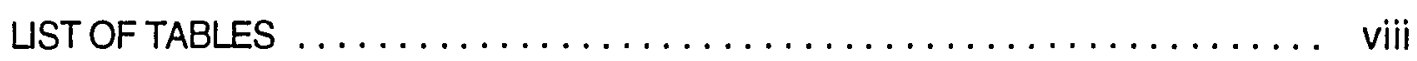

CHAPTERS

I THE RESEARCH PROBLEM $\ldots \ldots \ldots \ldots \ldots \ldots \ldots \ldots \ldots \ldots \ldots \ldots$

Introduction $\ldots \ldots \ldots \ldots \ldots \ldots \ldots \ldots \ldots \ldots \ldots \ldots \ldots \ldots \ldots \ldots$

Role of the School Business Official $\ldots \ldots \ldots \ldots \ldots \ldots \ldots$. 3

Need for Professional Training $\ldots \ldots \ldots \ldots \ldots \ldots \ldots \ldots \ldots$

Problem Statement $\ldots \ldots \ldots \ldots \ldots \ldots \ldots \ldots \ldots \ldots \ldots \ldots$

Research Questions $\ldots \ldots \ldots \ldots \ldots \ldots \ldots \ldots \ldots \ldots \ldots$

II REVIEW OF THE LITERATURE $\ldots \ldots \ldots \ldots \ldots \ldots \ldots \ldots \ldots \ldots$

Background $\ldots \ldots \ldots \ldots \ldots \ldots \ldots \ldots \ldots \ldots \ldots \ldots \ldots \ldots \ldots \ldots$

Current School Business Literature $\ldots \ldots \ldots \ldots \ldots \ldots \ldots .11$

Developing a Professional Training Program $\ldots \ldots \ldots \ldots \ldots$

School Business as a Profession $\ldots \ldots \ldots \ldots \ldots \ldots \ldots$

III DESCRIPTION OF STUDY PROCEDURES $\ldots \ldots \ldots \ldots \ldots \ldots \ldots, 21$

Objectives of the Study . . . . . . . . . . . . . . . . . . 21

Variables $\ldots \ldots \ldots \ldots \ldots \ldots \ldots \ldots \ldots \ldots \ldots \ldots \ldots \ldots \ldots, 22$ 


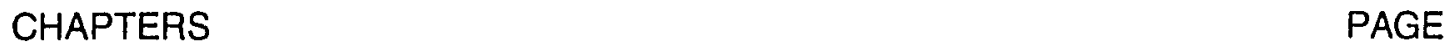

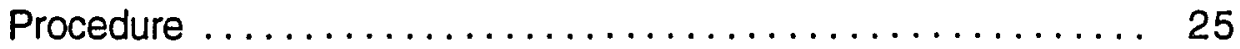

Survey Instrument $\ldots \ldots \ldots \ldots \ldots \ldots \ldots \ldots \ldots \ldots \ldots \ldots$

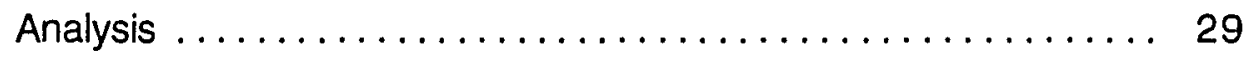

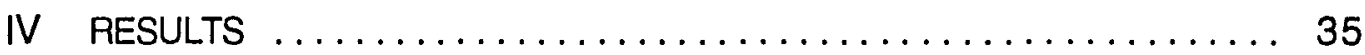

Characteristics of Respondents $\ldots \ldots \ldots \ldots \ldots \ldots \ldots \ldots$

Inquiry Questions $\ldots \ldots \ldots \ldots \ldots \ldots \ldots \ldots \ldots \ldots \ldots \ldots \ldots$

Analysis of Research Questions . . . . . . . . . . . . . 39

Research Question Results . . . . . . . . . . . . . . . 44

Inquiry Question Results $\ldots \ldots \ldots \ldots \ldots \ldots \ldots \ldots \ldots \ldots$

$\checkmark$ CONCLUSIONS AND RECOMMENDATIONS ........... 88

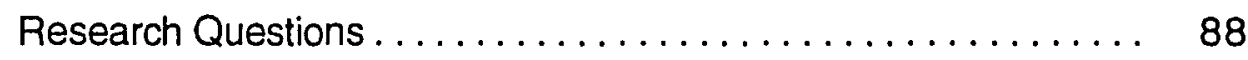

Inquiry Questions $\ldots \ldots \ldots \ldots \ldots \ldots \ldots \ldots \ldots \ldots \ldots$

Objectives Reviewed $\ldots \ldots \ldots \ldots \ldots \ldots \ldots \ldots \ldots . \ldots 9$

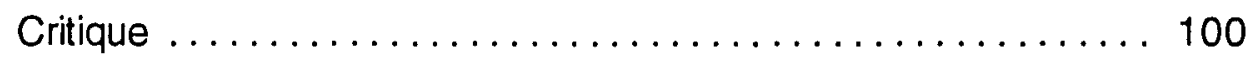

Open Comments ......................... 103

Summary .......................... 105

General Recommendations $\ldots \ldots \ldots \ldots \ldots \ldots \ldots \ldots \ldots$

Recommendations for Superintendents . . . . . . . . . . . . 107

Recommendations for Universities . . . . . . . . . . . . . 107

Recommendations for School Business Associations . . . . . . 107

Recommendations for School Business Officials . . . . . . . . 108 
Observations 108

Impact

Future Direction

REFERENCES

APPENDICES

A ASBO-I/DANFORTH MODEL PREPARATION PROGRAM FOR

SCHOOL BUSINESS ADMINISTRATORS

B SCHOOL BUSINESS REFERENCES COMPARED TO ASBO/ DANFORTH MODEL

C EXISTING SCHOOL-BUSINESS-OFFICIAL TRAINING MODELS COMPARED TO ASBO/DANFORTH MODEL

D MCGUFFEY COMPETENCIES COMPARED WITH THE ASBO/ DANFORTH MODEL ........................... 138

E SURVEY INSTRUMENT $\ldots \ldots \ldots \ldots \ldots \ldots \ldots \ldots \ldots \ldots \ldots \ldots \ldots \ldots$

F SURVEY ENVELOPE ........................... 147

G LETTERS TO SOLICIT SURVEY RESPONSES ........... 149

H POSTCARD REMINDER/THANK-YOU ............... 153

I RETURN ENVELOPE $\ldots \ldots \ldots \ldots \ldots \ldots \ldots \ldots \ldots \ldots \ldots \ldots \ldots$

$J$ CODE BOOK FOR VARIABLES OF PROFESSIONAL DEVELOPMENT NEEDED FOR SCHOOL BUSINESS OFFICIALS 
APPENDICES

PAGE

K SUMMARY OF COMMENTS .................. 163

L OTHER AREAS SUGGESTED FOR PROFESSIONAL DEVELOPMENT $\ldots \ldots \ldots \ldots \ldots \ldots \ldots \ldots \ldots \ldots \ldots \ldots$

M DESCRIPTION STATISTICS ...................... 169 


\section{LIST OF TABLES}

TABLES

PAGE

I Characteristics of Professions $\ldots \ldots \ldots \ldots \ldots \ldots \ldots \ldots, 18$

II Survey Variables by Category $\ldots \ldots \ldots \ldots \ldots \ldots \ldots \ldots, 23$

III Combinations of Variables Selected for Analysis . . . . . . . . 32

IV Characteristics of Survey Respondents in Order of Frequency . . 38

V Inquiry Questions on Importance ................. 40

VI Six Basic Research Questions formatted for Analysis ........ 43

VII Preferred Source $\ldots \ldots \ldots \ldots \ldots \ldots \ldots \ldots \ldots \ldots \ldots \ldots, 46$

VIII Educational Enterprise RQ2 $\ldots \ldots \ldots \ldots \ldots \ldots \ldots \ldots \ldots, 46$

IX Financial Resource Management RQ2 $\ldots \ldots \ldots \ldots \ldots \ldots \ldots, 47$

$X$ Human Resource Management RQ2 $\ldots \ldots \ldots \ldots \ldots \ldots \ldots, 47$

XI Facility and Property Management $R Q 2 \ldots \ldots \ldots \ldots \ldots \ldots, 48$

XII Information Management RQ2 $\ldots \ldots \ldots \ldots \ldots \ldots \ldots \ldots, 48$

XIII Management of Ancillary Services RQ2 ............. 49

XIV Educational Enterprise RQ3 $\ldots \ldots \ldots \ldots \ldots \ldots \ldots \ldots . \quad 50$

XV Financial Resource Management RQ3 .............. 50

XVI Human Resource Management RQ3 $\ldots \ldots \ldots \ldots \ldots \ldots \ldots .61$

XVII Facility and Property Management $\mathrm{RQ} 3 \ldots \ldots \ldots \ldots \ldots .61$

XVIII Information Management RQ3 $\ldots \ldots \ldots \ldots \ldots \ldots \ldots \ldots, 52$ 
XIX Management of Ancillary Services RQ3 .............. 52

$\mathrm{XX}$ Educational Enterprise $\mathrm{RQ} 4 \ldots \ldots \ldots \ldots \ldots \ldots \ldots \ldots \ldots$

XXI Financial Resource Management RQ4 ............. 53

XXII Human Resource Management RQ4 ... . . . . . . . . . . 54

XXIII Facility and Property Management RQ4 ........... 54

XXIV Information Management $\mathrm{RQ} 4 \ldots \ldots \ldots \ldots \ldots \ldots \ldots \ldots$

XXV Management of Ancillary Services RQ4 ........... 55

XXVI Educational Enterprise $R Q 5 \ldots \ldots \ldots \ldots \ldots \ldots \ldots \ldots \ldots \ldots \ldots \ldots \ldots$

XXVII Financial Resource Management RQ5 ............ 57

XXVIII Human Resource Management RQ5 .............. 57

XXIX Facility and Property Management RQ5 ........... 58

XXX Information Management RQ5 ............... 58

XXXI Management of Ancillary Services RQ5 ............. 59

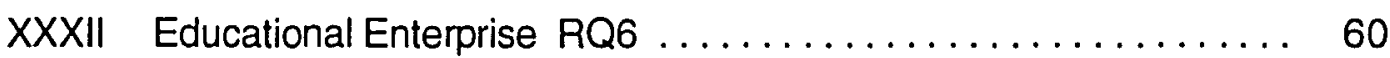

XXXIII Financial Resource Management RQ6 .............. 60

XXXIV Human Resource Management RQ6 .............. 61

XXXV Facility and Property Management RQ6 ............. 61

XXXVI Information Management RQ6 ................ 62

XXXVII Management of Ancillary Services RQ6 .............. 62

XXXVIII Inquiry Question 1 Results $\ldots \ldots \ldots \ldots \ldots \ldots \ldots \ldots \ldots \ldots$

$\mathrm{XXXIX}$ Inquiry Question 2 Results $\ldots \ldots \ldots \ldots \ldots \ldots \ldots \ldots \ldots$ 
$X \mathrm{~L}$ Inquiry Question 3 Results $\ldots \ldots \ldots \ldots \ldots \ldots \ldots \ldots$

XLI Inquiry Question 4 Results $\ldots \ldots \ldots \ldots \ldots \ldots \ldots \ldots \ldots \ldots$

XLII Inquiry Question 5 Results $\ldots \ldots \ldots \ldots \ldots \ldots \ldots \ldots \ldots \ldots$

XLIII Inquiry Question 6 Results $\ldots \ldots \ldots \ldots \ldots \ldots \ldots \ldots \ldots$

XLIV Inquiry Question 7 Results $\ldots \ldots \ldots \ldots \ldots \ldots \ldots \ldots \ldots \ldots$

XLV Inquiry Question 8 Results $\ldots \ldots \ldots \ldots \ldots \ldots \ldots \ldots \ldots$

XLVI Inquiry Question 9 Results $\ldots \ldots \ldots \ldots \ldots \ldots \ldots \ldots$

XLVII Rank Order Preference of Source for Professional Training of School Business Officials $\ldots \ldots \ldots \ldots \ldots \ldots \ldots \ldots \ldots . \ldots 4$

XLVIII Rank Order of Importance for Area of Professional Training of School Business Officials . . . . . . . . . . . . . . 86

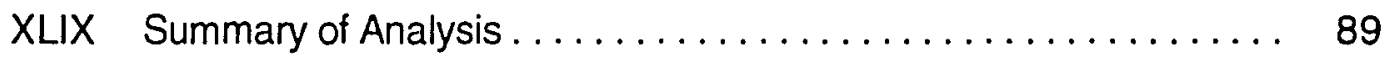

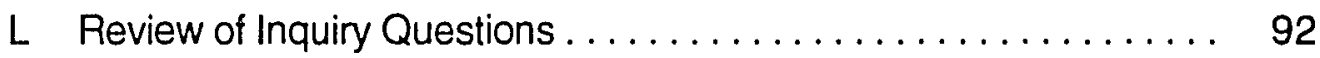


CHAPTER \|

\title{
THE RESEARCH PROBLEM
}

INTRODUCTION

\begin{abstract}
A school business official faces daily challenges in the role of educational administrator. The professional development needed to meet this challenge has not emerged in a common defined curriculum. This chapter addresses the history and the role of school business administration and presents a problem statement and research questions to help identify the critical components needed for professional development.

To provide effective educational programs, leadership is needed in both the educational and support-services areas. This study seeks to assist in meeting support-service training needs by identifying the necessary components for the professional development of the school business official. In this study, the term "school business official" (designated hereafter in this document as "SBO") refers to the person responsible for financial management and most other noninstructional services. This study includes a review of existing literature and programs and utilizes an existing model drafted by a task force of university professors and school business practitioners. The purpose of this study is to validate and enhance this model.
\end{abstract}


Educational leadership in kindergarten-through-twelfth-grade schools involves not only leadership in curriculum-related activities but also in educational support services. In a public school system, support services are the organizational components generally responsible for the management of financial, facility, food, transportation, and related noninstructional services. Qualified support-service managers have generally developed technical expertise and gained experience by focusing on their technical craft more than on the overall educational product. The two are not independent, as allocation of resources and educational support must be interrelated to provide the optimum educational product. The support-services leader must understand the organization's educational goals, just as the educational leader must understand how support services can help meet those goals.

The need for school business support is not new; in fact, as Hill (1982) indicates, school support administration emerged in the United States, in Cleveland, Ohio, as early as 1841 . (Note: A superintendent was not hired there until 1853.) Since 1910, SBOs have operated as a separate job classification with a professional association, currently Association of School Business Officials International, (ASBO-I). During this time, the emerging profession has developed a vibrant association, a code of ethics, a common body of knowledge, professional autonomy, and a cadre of committed school business practitioners. What has not developed, however, is a formalized training program for becoming an SBO (Dierdorff, 1988). 
In an effort to solve this problem, ASBO-I has provided a forum for written discussion in its professional journal, School Business Affairs, and has sponsored a June 1988 symposium to clarify issues and raise awareness of the needs of SBOs (Dierdorff, 1988). Topics at the symposium included certification, professional development, evaluation of the school business function, recruitment, and retention. Current training programs and developments from various states and provinces were also reviewed.

An outgrowth of this symposium was an ASBO-I and Danforth Foundation project that brought together practicing SBOs and representatives of various university educational administration programs. The group developed an outline of a model curriculum for SBOs in the United States and Canada. The model, described in more detail later, serves as the basis for this research project (see Appendix A).

\section{ROLE OF THE SCHOOL BUSINESS OFFICIAL}

School business administration references profess that educational support services exist for the sole purpose of facilitating the educational program (Hill, 1982). In some cases, support services are identified as a subset of educational administration. This viewpoint places support services as a part of school administration, performing only those activities that support education and none that are ends in themselves (Knezevich and Fowlkes, 1960). Another perspective is the team approach, wherein the support-services role, as 
described by Nelson and Purdy (1971), operates parallel to the educational program, providing the necessary buildings, equipment, and supplies. This approach brings support services into a shared-goal relationship with the educational leader--for the improvement of education.

The role of an SBO is very complex. Not only does the role vary by the size of the district and the timing of work projects, but Hill (1982) notes that the role also covers 21 general areas that can be categorized into 130 distinct activities needing different skills and knowledge.

Candoli, et al, (1984) see the SBO as a technical specialist, conceptual consultant, and administrative generalist. The complexity of the role is compounded by the interrelationships with the superintendent and other members of the general educational administrative team. The SBO must support the superintendent not only in technical areas, but in planning, human relations, and political areas as well.

The role requirements of SBOs are related to specific locations and points in time. As Jordan, et al, (1985) note, the SBO may be doing support and line work simultaneously. The primary role is to support the educational process, but there is no uniform job description, and needs vary by district. Facing this challenge, the SBO must adapt to organizational goals, balance technical needs with educational needs, focus both on efficiency and effectiveness, and be flexible in response to regulated requirements. 


\section{NEED FOR PROFESSIONAL TRAINING}

Generally, SBOs are assigned as their school systems' managers for the areas of finance, facilities, food service, transportation, and risk management. Although some SBO programs are in place, SBOs usually become proficient in managing this broad responsibility through an individualized program of self-directed, on-the-job training. Given the complexity of the SBO role, the development of professionals to perform that role is critical and likewise complex. The challenge is to develop a program which will cover the breadth of technical knowledge needed, political influences, and situational requirements within a reasonable time frame.

This research project seeks to identify perceptions of the critical components needed for a professional-development program for SBOs. In addition to identifying the scope of training, insight into the relative importance and preferred sources for implementing such programs will also be sought.

The need for agreement is becoming more critical because of increasing concerns such as:

1. The movement to achieve excellence in schools, but without adding resources.

2. Shortage of SBOs in the next few years (Wagner, 1990; Moore 1990).

3. The few existing programs for preparing SBOs do not have a common curriculum, which limits transfer of certified officials to different locales.

4. The job of an SBO is becoming more complex and changes regularly. 
5. Schools are one of the biggest businesses in any community. As Everett \& Everett (1988) note, SBOs annually handle more than $\$ 100$ billion and, considering the value of physical plants, manage nearly a trillion dollars of public assets. (California's ASBO affiliate estimates that that state, alone, has facilities exceeding $\$ 60$ billion in value.)

The need for a professional-development program for SBOs is further accentuated by factors external to the profession. Candoli (1984) refers to a revolution in school business, citing the following as factors that are making it more extensive and more intensive:

1. Changing enrollment.

2. Taxpayer revolt.

3. Restricted funds.

4. Increased demand for both educational and financial accountability.

5. Increased technological advances.

6. Increased legislative demands for compliance.

Jordan, et al, (1985) identify some of the same changes in the Education industry, adding others. Their additions include:

1. Authoritative management being replaced by participative styles.

2. Increases in collective bargaining.

3. Increases in complexity due to the size of districts.

4. Impact on the degree of public support based on the reputation of the financial, facility, or other support-service operations. 
The current need is summarized well by Hentschke (1986), who notes that school business is undergoing fundamental changes. No longer can a common-sense base serve a school official, as the role requires extensive technical knowledge. Current school business technical areas were not even known a few years ago (e.g., asbestos, microcomputers). Further, there is no formalized and agreed-upon body of knowledge guiding either the training or the hiring of SBOs. Adding to this complexity is a wide range of requirements across districts. SBOs in the future can expect to become process managers for an even greater variety of services.

\section{PROBLEM STATEMENT}

With this expressed need, the problem is: What are the critical curriculum components needed to develop effective SBOs? This project sought to determine the perceptions of the parties affected by school business regarding the appropriateness of the model curriculum generated by the ASBO-1/Danforth task force. Members of ASBO-I are considered representative of the recipients of the proposed training, and university educational-administration program faculty represent the providers. For further insights, a sample of school superintendents was surveyed to gather the customers' points of view of school business services.

Kerlinger (1986) suggests that a problem statement should show a relationship, imply a research direction, and be presented in the form of a 
question. The problem presented within these guidelines is: How do the critical training-program components needed for the development of effective SBOs differ according to the variables of respondents' positions and personal or organizational demographics?

\section{RESEARCH QUESTIONS}

To address the problem, three general research questions are offered:

1. What components of a school business professional development plan are considered important to the parties surveyed?

2. What is the preferred source to provide the desired professional development training?

3. What similarities and differences in perception exist among those surveyed based on their positions and demographic distinctions? 
CHAPTER ॥

\section{REVIEW OF THE LITERATURE}

\section{BACKGROUND}

The development of future SBOs requires an understanding of what currently exists. This chapter presents the current status of SBO professional development and summarizes the literature available on school business administration. Likewise, an understanding of the nature of professions and professional training in general adds insight to the current status in the evolution of school business as a profession. This chapter addresses the nature of professions, as well, and relates them to school business.

Even with the large number of dollars involved and the need for public accountability, few formal SBO training programs exist, and those that do are not standardized. In 1988 sixteen states and four Canadian provinces had some type of certification requirements (Everett \& Everett, 1988). Some programs have developed narrowly in one area, such as finance. Others have evolved from school-district administrators' programs and require teaching experience. Ten states require a bachelor's degree as an education minimum (Drake, 1990).

The scope of training is complicated by the roles of SBOs. According to 
Wagner (1990), the SBO needs to be a generalist and a specialist. Skills required include executive skills, managerial skills, and technical skills. Further, the degree, frequency, and level of skills varies with the size, location, and expectations of the individual district.

An emerging interest in formal standardized training for SBOs exists. Six additional states and four Canadian provinces are considering a standard program (Everett \& Everett, 1988). However, the main source for SBO professional development remains on-the-job experience. Even so, 87 percent of SBOs surveyed felt they were well trained, but 70 percent felt it took a long time to obtain that training (Candler, 1987). The satisfaction level may be more a factor of professional commitment by SBOs than of having any commonly recognized standard by which to measure the adequacy of their training.

In this environment of emerging awareness, the most comprehensive project undertaken for a formal standardized program has been a joint effort by ASBO-I and the Danforth Foundation. Initiated by ASBO-I and funded by the Danforth Foundation, the project task force was charged with formulating a model professional development program for school business administrators. The task-force membership consisted of ten university and ASBO-affiliate teams representing nine states and one Canadian province (including Portland State University and this author). The selection represented a geographic diversity and an early expression of interest. Those selected expressed commitment to trying a pilot program based on the model developed. 
Representatives met in February 1989 and drafted a program outline to review with the appropriate faculty or association boards. In May 1989 the group reconvened and produced the current model (Appendix A) and the recommendation that the program be at a master's level. Subgroups were assigned the task of providing more detail to the outline, but that step has not been completed due to lack of funding.

In summary, the model was to be:

1. Based on traditional educational-administration graduate course work with added school-business content.

2. Voluntary and not tied to a certification program.

3. Coordinated with business, law, or public-administration courses available at the respective universities.

4. Operated as a pilot program (no formal evaluation criteria were defined).

\section{CURRENT SCHOOL BUSINESS LITERATURE}

Current literature addressing the training of SBOs falls into two categories. First, textbooks on school business administration offer a wide range of subject matter for SBOs to absorb. Second, existing program brochures or references provide a mix of focused and broad-topic areas.

To analyze the existing literature, two matrices were prepared using the ASBO/Danforth model as a guide. Textbooks available from ASBO and the 
Portland State University library were reviewed to confirm which of the model areas had already been identified. Textbooks were considered representative sources of the topics covered in most educational-administration programs (see Appendix B). Those topics identified by terms different from those used in the ASBO-I/Danforth model were grouped within the categories and terminology of the model. (Note: Variations in terminology among the authors may result in the inadvertent omission or duplication of a topic.)

All states and provinces identified by Everett \& Everett (1988) as having an existing program were contacted to obtain program information. This group is considered representative of the current professional-development programs for practitioners. The information received is summarized in Appendix $C$ in the same manner as the textbook summary.

Studies on the role and needs of a school business official are limited. The textbooks and program information identified topical job areas of school business but only superficially addressed the nature of the work and the needed training. The only needs identification for SBO training discovered in the literature was a 1980 study done by C. W. McGuffey. As a professor of educational administration at the University of Georgia and a member of ASBO, MCGuffey sought to identify competencies needed by the chief SBO. The intent was to develop both preparation and continuing-education programs for SBOs. A comparison of McGuffey's competencies with the ASBO/Danforth model is included in Appendix D. 
The matrices validate common categories of or differences from the ASBO/Danforth model. These patterns are the basis for identifying the components in the survey that reflect current programs as well as the proposed model. No references found addressed the unique nature of school business compared to public administration or general business administration. In this author's observation, many technical and managerial skills needed are applicable and interchangeable among the different administrative disciplines. The most apparent differences are in the environment and organizational roles facing administrators in the various areas. In an educational culture, business is a support function; in business, education is a support function.

\section{DEVELOPING A PROFESSIONAL TRAINING PROGRAM}

One approach to setting standards is mandating a certificate or license without a comprehensive professional-development program design. This approach focuses on an answer without identifying needs and objectives. For illustration, given the scope of an SBO's tasks, requiring a certificate in school finance only is similar to requiring medical doctors to be trained in the respiratory system while expecting them to practice on the entire body. An overview of professional training and professions in general helps identify the role of a comprehensive training program in the development of a profession.

The concept of licensure or certification of SBOs is under review by ASBO-I affiliates (Everett \& Everett, 1988). Even advocates suggest changes 
such as incorporating tiers, or levels, of certification (Griffiths, Stout \& Forsythe, 1988). This suggestion was generated by environmental requirements that professions shift from a one-time, entry-level competence to lifelong learning (Klevins, 1987; Houle, 1980). A system of lifelong learning includes an evaluation component (Houle, 1980). Because of the need for accountability, some professions have added mandatory continuing-education requirements (Long, 1983).

Houle (1980) identifies other environmental changes impacting adult education, including life style and job requirements. In addition, organizational missions are constantly changing to respond to environmental changes.

Another factor to consider in developing programs, according to Houle (1980), is the variety of competition for professional programs, including:

(a) self-instruction, (b) associations, (c) employers, (d) professional schools, (e) universities, $(f)$ independent providers, and $(g)$ purveyors of supplies and equipment. More learning is done by self-instruction than by all the others (Long, 1983).

The challenge of programs in such a diverse environment is to recruit trainees to an exciting, high-powered program (Griffiths, et al, 1988). An additional challenge is to collaborate with associations, employees, and others to share in the total training market (Gessner, 1987).

Indicators of a successful program vary by the objectives sought and, as noted by Knox (1987), by the audience seeking the evaluation. Houle (1980) 
suggests five indicators of success for a professional program:

1. Clarification of functions.

2. Mastery of theoretical knowledge.

3. Capacity to solve problems.

4. Use of practical knowledge.

5. Self-enhancement.

Houle (1980) also offers a variety of measurements:

1. Participation.

2. Learner satisfaction.

3. Accomplishment of learning plan.

4. Performance of learned skill.

5. Peer appraisal.

6. Self-assessment.

7. Formal employer appraisal.

McLagan (1978) reminds us that the focus of a good program should be on learner needs, not instructor needs. She indicates that successful activities are those that generate the outcomes desired. The key to the program evaluation process is knowing the needs of the student and the objectives of the program.

Knox (1987) provides further insight when he relates program development and evaluation to marketing. The critical elements of marketing are to identify the needs of customers and offer them something of value in 
exchange for the time and/or money commitment to participate in an adult learning program.

Program development should focus on three key elements:

(a) learners' needs, (b) expressed objectives and designs, and (c) formal evaluation.

These elements can be enhanced by variety and flexibility. In today's environment, collaboration also should enhance program development. Both the needs and competition are increasing, and it seems unlikely that one program can meet all needs.

Each of the three key elements should be future oriented. The learners that are in programs now will perform in the environment of the next $30-10-40$ years, not in the world their predecessors have left. What was successful in the past should be considered but not extrapolated "for old times' sake."

Regardless of the quality of the educational program, both learners and providers must keep the perspective of reality. The true test of a professional program's effectiveness is not that learners are competent to do a job but that they are actually doing an effective job (Cross, 1982).

\section{SCHOOL BUSINESS AS A PROFESSION}

To generate a comprehensive review of a professional-development program, investigation into the nature of a profession is necessary. Although not the primary area of this study, an understanding of professions will assist in the 
implementation of any alternatives generated.

Defining a profession is not an easy task. In fact, in his article, "The Theory of Professions," Freidson concludes that each writer should individually define the term and give examples (Dingwall and Lewis, 1983). A more practical approach is needed to evaluate the occupation of SBO.

To provide a basis for comparison, I surveyed the work of eleven writers identified in the Portland State University library reference under the "professions" category. They defined "professional" by groups of characteristics. The authors and the 16 characteristics they identified are summarized in Table I. A tally of the frequency of each characteristic reveals five clear areas of agreement on what comprises a profession:

1. A professional association

2. Professional authority/autonomy

3. A specific body of knowledge

4. A code of ethics

5. A commitment or calling

A review of the remaining features, with specific attention to the interrelation of standards and training and the differences in terminology among writers, reveals another characteristic that can be added to the consensus: $A$ formal, standardized training and self-regulation program.

Additional points from the literature help describe a profession. First, the evolution of professions has historically been aligned with universities or 
TABLE I

\section{CHARACTERISTICS OF PROFESSIONS}

1. Specific Body of Knowledge

2. Professional Authority/Autonomy

3. Community Sanction

4. Code of Ethics

5. A Professional Association

6. Commitment/Calling

7. Standards/Self-Regulation

8. Length of Training

9. Full-Time Occupation

10. Service Orientation

11. Formal Training Schools

12. Monopoly

13. Screening to Assure Competence

14. Reward Symbolic of Achievement

15. Remuneration Via Fees

16. Opportunity to Move To Other Locales

(References: Ammons \& King, 1982; Benveniste, 1987; Dingwall \& Lewis, 1983; McGowan, 1982; Moore, 1970; Moyer, 1985; Pavalko, 1971; Pavalko, 1972; Raelin, 1986; Riggs, 1982; Vollmer \& Mills, 1966.) 
churches (Larson 1977), indicating both their association with liberal education and their history of sharing responsibility. Another aspect of a profession is the nature of the work. Benveniste summarized this, "Professionals solve problems, not push paper" (1987). This concept emerged as "service orientation" among the characteristics identified earlier. What is being done by a professional should be perceived as valuable to the community. In a profession the work itself, in addition to those who effectively perform it, appears to be worthy of prestige and respect.

In the future, professions will not exist in the mold of the past because they are changing, with many occupations in transition toward professionalism; and organizations are continually providing new settings for professionals. To clarify the changes, Moore classifies professionals into three types (1970).

1. The traditional free professional, with an unorganized clientele and a high degree of autonomy.

2. The professional within an organization but with an unorganized clientele.

3. The professional within an organization with a clientele within the organization and a lesser degree of autonomy.

This distinction is based on the premise that the organizational environment affects autonomy. In school administration, autonomy has traditionally been restricted.School systems place the administrator in a highly vulnerable position. 
Decisions have been and continue to be made less on educational grounds than to appease critics. This results from the system and its environment, not from poor administrators. The solution, then, is to reduce the vulnerability of school systems and improve the training of administrators (Callahan, 1962); the former is a task for society, but the latter is within the reach of school business administration as a profession. 
CHAPTER III

\section{DESCRIPTION OF STUDY PROCEDURES}

\section{OBJECTIVES OF THE STUDY}

The objectives of this study are to answer the following general questions posed at the end of Chapter I:

1. What comporients of a school business professional development plan are considered important to the parties surveyed?

2. What is the preferred source to provide the desired professional development training?

3. What similarities and differences in perception exist among those surveyed based on their roles and demographic distinctions?

To determine the answers in a measurable format, the following six specific questions will be tested:

1. Is there any significant difference regarding the generally preferred source of training, that relates to the respondents' five geographic locations?

2. Is there any significant difference regarding the preferred source of training for the six general areas, that relates to the job responsibilities of respondents?

3. Is there any significant difference regarding the preferred source of 
training in the six general areas, that relates to the university respondents university type?

4. Is there any significant difference regarding the importance of the six general areas, that relates to the annual budgets of respondents' districts?

5. Is there any significant difference regarding the importance of the six general areas, that relates to respondents' school business experience?

6. Is there any significant difference regarding the importance of the six general areas, that relates to the job responsibilities of respondents?

The chapter presents the variables involved and the procedures for gathering and analyzing data to answer these questions.

With the ASBO/Danforth model as a foundation, this research study surveyed perceptions of those involved in receiving or providing professional SBO training. This research did not collect data regarding curriculum sequence, methods, or materials, although some tentative recommendations could evolve from the available data.

\section{VARIABLES}

In structuring the research project, the independent and dependent variables must be identified. These variables, both nominal and ordinal, are summarized by category in Table II.

The selection of the independent variables is based on the role of three vested-interest groups: SBOs, superintendents, and professors of 
TABLE ॥

\section{SURVEY VARIABLES BY CATEGORY}

Categery

Nominal

Ordinal

\section{Independent}

Gender

Responsibility

District type

Location

University type

\author{
Dependent \\ Preferred training source
}

Importance
Age
School-business experience
District's annual budget

Education

educational administration. SBOs who are members of ASBO represent the targeted clientele or ultimate users of any program for professional development. They also represent the membership of local and international ASBO organizations, currently the most common providers of school business professional development. This group does not, however, represent a majority of school districts. In the United States there are 15,358 school districts (National Center for Educational Statistics, 1992). As Moyer (1985) indicates, there are about 6,350 U.S. members of ASBO/I, many of which represent library memberships or multiple members from the same district.

The superintendents represent the employers of SBOs. This perspective is needed to assure that professional development is directed not only toward what an SBO would like but also toward what the employer needs. Professors in universities with education-administration programs represent major 
providers of school business training and also represent a group that is aware of the culture of educational organizations as a whole, not just as a business or support-service component.

The characteristics selected to distinguish among these groups are based on my personal experience. For example, school business departments within the same state or province differ in budget size, location, and management philosophy. Of these three, budget size and location can be objectively recorded. Personal demographics variables may identify differences in the customers of school business training. If respondents with specific characteristics place different levels of importance on the training topics, the providers can target programs to meet specific market needs.

Differences in school business training programs exist among states and provinces due to local laws and how the education system developed, but many problems and concerns are shared. Common bonds, if identified, would support common training development and perhaps enhance advancement opportunities for SBOs.

For universities, the distinction focuses on whether the institutions see themselves primarily as trainers of practitioners or as major research universities. If differences exist, the category more aligned with SBOs would appear to be more likely to develop a partnership with ASBO affiliates to provide school business training. 


\section{PROCEDURE}

The procedure used for the research is:

1. Review literature to identify existing programs or models.

2. Analyze the components of existing programs in the identified states and provinces to determine the scope of topics covered.

3. From the information gathered, identify topics similar to or different from those in the ASBO-1/Danforth model.

4. Develop a survey instrument for representatives from ASBO-I membership, education-administration programs, and school superintendents. The survey included the variables identified earlier as well as an opencomments question.

5. Pilot the survey with a small group of Oregon SBOs, the ASBO-I professional-development committee, and education-administration professors.

6. Evaluate and refine the pilot surveys.

7. Distribute the survey by mail.

8. Analyze the data using the SYSTAT statistical computer program.

9. Develop and document conclusions, and offer specific recommendations.

The primary source of data for this research was a written survey. The survey method allows contact with a large number of subjects in an economical manner. The mailed survey also allows contact with respondents from a large geographic area and different demographic backgrounds. 
Although subject to misinterpretation (Ary, 1985), the written survey focuses on a defined problem and specific objectives that, upon analysis, can generate more acceptable recommendations than just a subjective evaluation. Although a survey limits the depth of inquiry, this research seeks only to address scope and provide direction for further detail. Further, because the objective of this project is to confirm the incidence of agreement among recipients, beneficiaries, and providers of school-business training, the survey data offers a convenient measurement format.

A survey also has some political advantages. The issue of professional standards raises concerns among incumbent SBOs. Each SBO has a personal and financial investment in the programs that may evolve. Surveys allow a representative group of SBOs to express an opinion. This may affect acceptance of the resulting program as well as participation. No professionaldevelopment program can be effective if the target audience doesn't attend.

Selection of the sample school-business group was based on a geographic representation of the ASBO-I membership, which was divided into five geographic areas, four for the United States and one for Canada. Within those areas, ASBO-I staff selected members at random, including representatives from each state and province. This stratified random sampling drew 466 names (approximately 50-100 respondents from each geographic area) from a total of 6,600 members. The sample actually generated 500 names, but memberships that were obviously libraries or vendors were deleted. 
The superintendent and educational-administration samples were selected from the membership of national-level organizations. ASBO-I also provided 100 randomly selected names from the superintendent members. The National Council on Accreditation for Teacher Education (NCATE), a university organization for the accreditation of educational-administration programs, provided another randomly geographic group of 100 member schools. These two groups of 100 represent the beneficiaries and providers of school-business professional development programs.

Evaluating the data identifies not only the degree of support for curriculum components but also any deviations from the model or existing programs. The inquiry may also provide direction for further study of what makes an effective SBO. The resulting information should also prove helpful to those states and provinces interested in developing a program.

Although this is a survey of perceptions at one point in time, the format can be used for future replication. Because the survey itself created an awareness of the need for professional development, it may serve to initiate communication on professional-development programs.

\section{SURVEY INSTRUMENT}

The survey instrument (Appendix E) includes questions on the components identified in the literature review and in the ASBO/Danforth model. The survey data also distinguishes between the three groups surveyed. 
The survey was formatted to match the ASBO/Danforth model. The number of questions is within the range suggested by Dillman (1978), even though the scope of the SBO job is broad. It is assumed that the sample groups selected from association memberships would have a vested interest in completing the survey because of their professional commitment.

The survey instrument was prepared using a Maclntosh computer and printed in a booklet format generally following guidelines presented in Mail and Telephone Surveys, by Dillman (1978). Efforts were made to present the survey in a manner that maximizes the chances of receiving a response. As noted by Dillman, a total design method of the survey addresses not only the questions asked but the appearance and ease of responding to the survey. In addition to the booklet format, techniques he suggested to encourage responses include a professionally prepared envelope (Appendix F), cover letters (Appendix G), follow-up postcards (Appendix $H$ ), and prepaid return envelopes (Appendix I). The graphic design of a man seated at a desk was duplicated on the envelope, the survey, and the reminder postcard in order to visually connect the three and coordinate the overall design.

Because the survey sought attitudes, the cover letters (Appendix G) approached the respondents as if they were consultants. As a technique to personalize the letters but avoid using 700 names, three different letters were sent: to school business administrators, to superintendents, and to deans of educational administration. 
The letters included:

1. A request for advice.

2. A reference to the individual's personal experience and the value it would provide to help the profession.

3. Notes of thanks and appreciation.

4. Reference to the open-ended questions, acknowledging that those contacted could add to the knowledge of the task force.

5. A personalized signature.

An additional level of credibility was provided by ASBO International's endorsement and cosponsorship of the research project. The survey was sponsored by the ASBO-I board of directors, as recommended by the professional-development committee. ASBO-I allowed its name to be used on the survey, letter, and postcards. In addition, it provided $\$ 250$ to offset survey expenses. The surveys were mailed March 4, 1992; and on March 20 the follow up postcards of thanks were distributed, as suggested by Dillman, to serve as both a reminder and a trust-builder. Of the surveys received, 79 arrived at least a week after the final reminder.

\section{ANALYSIS}

As noted in Bogdan and Biklen (1982), a plan for analysis is needed once the data are collected. The general plan for this research analysis 
includes:

1. Organizing the data into categories.

2. Analyzing the data using various statistical techniques.

3. Looking for patterns, relationships, and unanswered questions.

4. Making notes of observations and questions arising during analysis.

More specifically, steps in the general plan include:

1. Codify the responses.

2. Enter the data into the computer system for analysis.

3. Identify the statistical techniques for analysis.

4. Describe the results.

5. Relate the results to the research questions.

6. Discuss the results and determine conclusions.

7. Report on qualitative responses.

8. Critique the analysis.

The responses from each survey were coded by identifying each variable in sequence, defining that variable, and indicating its value. $A$ code book is included as Appendix J.

The initial approach to this analysis was the definition of research questions as noted earlier. Identifying measurable responses also enhances the analysis.

With the number of independent nominal variables (5) and preferred training sources (31), there are 155 possible nominal comparisons to consider. 
The ordinal variables (4) times the importance values (31) produce another 124 possible combinations. Some of these combinations may be of interest to ASBO-I to understand the nature of the membership, and some combinations may generate interesting questions for future study.

For the purpose of this study, however, the number of combinations to be analyzed will be limited to key combinations that are expected to provide information on designing professional development programs or to address issues where differences of opinion are expected.

The selection of these combinations is based on the author's reasonable judgment and experience in school business. Other combinations emerging that indicate a difference of opinion will be investigated but are not considered essential to the study.

The key combinations and the basis for selection are summarized in Table III. Two of the six questions (Questions 1 and 6) were expected to generate significantly different responses. Based on experience and on the responses from pilot surveys, 1 expected respondents from the west to prefer continuing education or experience while other geographic areas may prefer a preparatory college program. The other expected difference was in the responses generated by Question 6. I expected superintendents and university representatives to consider the Educational Enterprise of higher importance as a training area than SBOs do.

The statistical technique used to analyze the questions will be a 


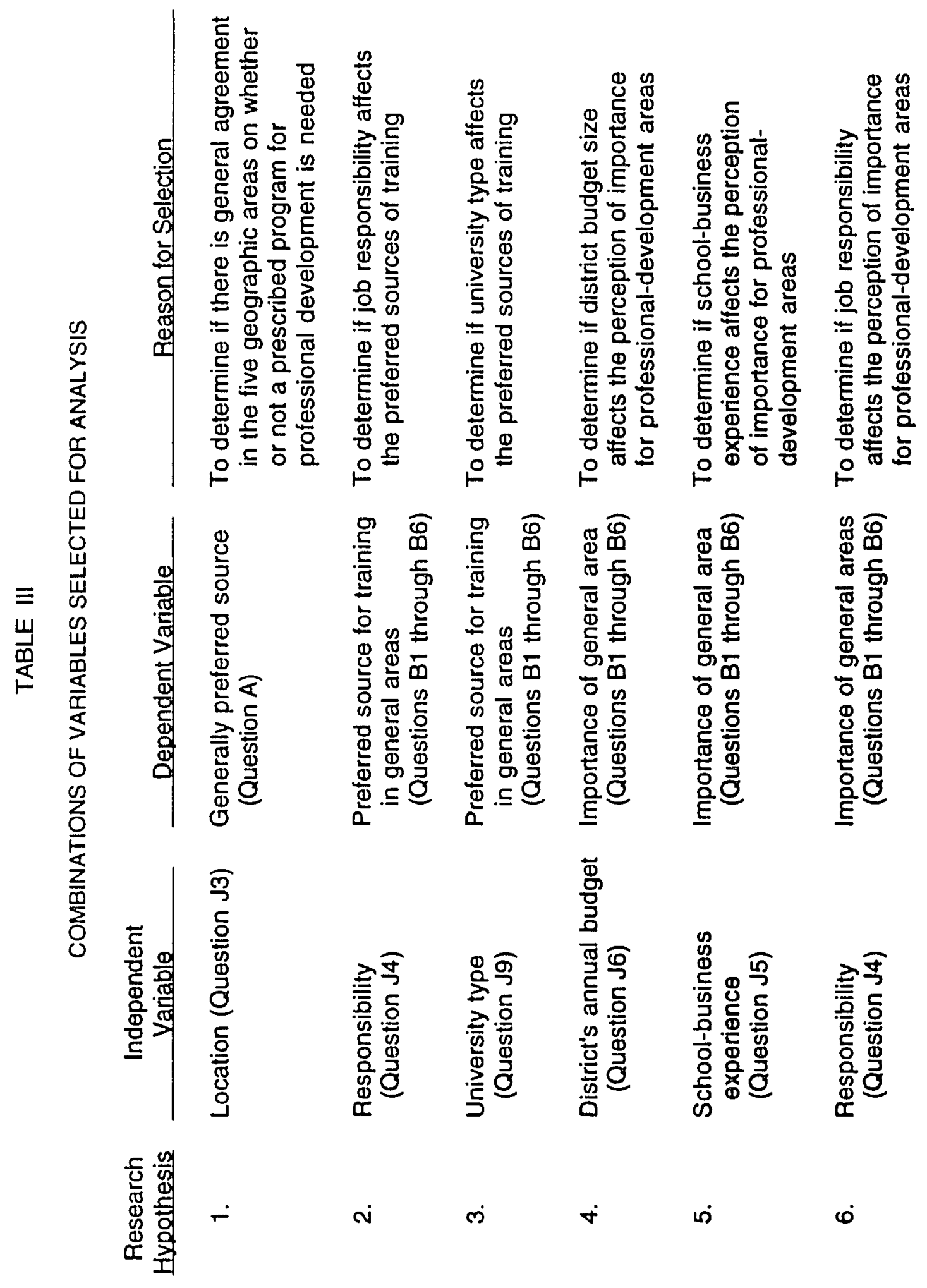


chi-square analysis. This will be used for each type of variable combination.

Other observations may emerge during an investigative review of the data. Findings in this area will not be reported based on analysis but only as comments. Investigative review will be done through descriptive statistics. The open-ended comments will be reviewed to see if any pattern of "other" categories or comment is evident.

Each subgroup of questions $B$ through $H$ will be reviewed to determine if the pattern of response for each subgroup is apparently different from the general category for preferred source of training. The mode of ratings for each subgroup will be compared to the mode of the general group. Likewise, a comparison will be made to determine if the pattern of response for each subgroup is apparently different than the general category of response for importance. The median of the subgroup ratings will be compared to the median of the general group. Further analysis will be done using only the general category and any apparently different subgroups.

The results--and their significance--will be described in a narrative, using tables where applicable. From the results and conclusions, recommendations will be offered. The open-ended comments will be summarized and subjective conclusions offered, as appropriate.

In conclusion, a critique of the study will be offered. This will include the advantages and limitations of the information resulting from the analysis of the research questions and the open-ended comments. 
As with any research, the actual results of the survey may alter the direction of the plan presented. Adjustments will be made as necessary. 


\section{CHAPTER IV}

\section{RESULTS}

As indicated in Chapter III, samples of 466 school business officials, 100 superintendents, and 100 representatives from educational-administration programs were surveyed. Within two weeks of the survey, 48 responses were received. No more than 8 came on any one day until the fifteenth day. For the next eight days responses came in at the rate of $24,18,28,49,3,14,10$, and 23 per day. From then until two months after the survey had been sent, responses arrived almost daily in groups of 1 to 6 . After three weeks with no further responses, the survey was considered complete and data entry began. The total number of responses was 253 (a response rate of 38 percent), 2 with comments only and 251 marked with statistical data as requested. By subgroups, the response rate were: SBOs, 42 percent; Superintendents, 35 percent; and universities, 37 percent.

In addition to the survey responses, some written comments (as summarized in Appendix K) were received. Respondents were also asked to suggest any other areas that should be considered for SBO professional development. These are listed in Appendix $L$. The relevant points in the comments that did not fit in another existing category were the need for an understanding of politics and ethics. 
Some editorial comments were noted as well. The instruction block preceding question $\mathrm{J} 5$ in the survey (Appendix E) should have preceded question 4. As a result, two university respondents wrote in their responsibilities on question 4. Question J7 could have had an "other" or "combination" category, as some respondents noted they were from districts that didn't fit just one description. There was also a response from a Department of Defense school.

After the data were entered into the SYSTAT 5 statistical program, a descriptive statistics summary was produced (Appendix M). This information was reviewed to identify the characteristics of the sample group and any unusual relationships that would indicate an area for inquiry in addition to the basic six research questions.

As noted in Chapter III, areas where a difference was indicated or where an unusual result might occur were analyzed. Areas of obvious agreement or expected results were not investigated. One example is the subgroup areas, where in most cases, responses were similar to those of the respective general areas, so only the general areas were analyzed. Another example of obvious agreement with the descriptive review is that university respondents generally agreed with the other respondents as to the importance of each general category. An obvious result was that university respondents consistently preferred college course work to workshops for each general area. 


\section{CHARACTERISTICS OF RESPONDENTS}

A summary of the characteristics of the respondent group is shown in Table IV. Most respondents were male (76.9\%). Over half had more than ten years' experience (50.6 percent) or a graduate degree (57.4 percent). This indicates that although no generally accepted professional training for SBOs is identified, this group has been in the field for some time and has sought formal education. The members' experience is reflected in the age characteristics, with more than 80 percent being over 40 years of age. The "no response" numbers are reflective of the question asked specifically for school district and university respondents.

\section{INQUIRY QUESTIONS}

A review of the descriptive data generated additional questions. These generally address the importance of an area perceived among respondents of differing characteristics. The first eight questions are summarized in Table V.

Other inquiry questions, not related to the respondent characteristics, were raised. These include:

Inquiry Question 9: Is there any significant difference perceived between the respondents on the value of knowing the foundations of teaching and learning as compared to the value of staff development?

Inquiry Question 10: Which areas of training are considered the most important, by rank order? 
TABLE IV

\section{CHARACTERISTICS OF SURVEY RESPONDENTS IN ORDER OF FREQUENCY}

\section{Characteristic}

Age:

40 to 49

50 to 59

30 to 39

60 or older

Under 30

Gender:

Male

Female

No response

Location:

U.S. midwest

U.S. west

U.S. east

U.S. south

Canada

Responsibility:

Business administrator

Business specialist

Superintendent

No response

School-Business Experience:

10-plus years

6 to 10 years

0 to 5 years

No response

District Annual Budget:

$\$ 10$ million to $\$ 50$ million

Less than $\$ 10$ million

More than $\$ 50$ million

No response
87

Number of Respondents \% of Total

$\begin{array}{rr}101 & 40.2 \\ 81 & 32.3 \\ 45 & 17.9 \\ 20 & 8.0 \\ 4 & 1.6 \\ & \\ 193 & 76.9 \\ 57 & 22.7 \\ 1 & .4\end{array}$

34.7

65

25.9

48

19.1

13.9

6.4

16

152

60.6

46

18.3

35

13.9

18

7.2

127

50.6

59

23.5

43

17.1

22

8.8

101

40.2

73

29.1

53

21.1

24

9.6 
TABLE IV

CHARACTERISTICS OF SURVEY RESPONDENTS

IN ORDER OF FREQUENCY

(continued)

Characteristic

Number of Respondents

$\%$ of Total

District Type:

Rural

Suburban

Urban

No response

Education:

Graduate degree

Bachelor's degree

High school/college

No response

University Type:

4-year, with a graduate professional program

Comprehensive program

Research

Doctoral

No response
96

82

48

25

144

63

23

21

19

11

4

3

214
38.2

32.7

10.0

57.4

25.1

9.2

8.4
19.1

Inquiry Question 11: Which sources of training are preferred for the various areas, by rank order?

\section{ANALYSIS OF RESEARCH QUESTIONS}

As indicated in Chapter III, six research questions were identified for analysis. They are:

1. Is there any significant difference regarding the generally preferred source of training, that relates to the respondents' five geographic locations? 
TABLE V

INQUIRY QUESTIONS ON IMPORTANCE

Based on the following characteristics of respondents, is there any significant difference in the perceived importance of the areas of training noted?

Characteristics of Respondents

1. Responsibility

2. Budget

3. Age

4. Gender

5. Location

\section{Areas of Training}

1. a. Foundations of teaching and learning

b. Staff development

c. Supplies and equipment management

d. Real-estate management

e. Program evaluation, research, and analysis

2. a. Health and safety

3. a. Educational enterprise

b. Financial resource management

c. Human resource management

d. Facility and property management

e. Information management

f. Management of ancillary services

4. a. Educational enterprise

b. Financial resource management

c. Human resource management

d. Facility and property management

e. Information management

f. Management of ancillary services

5. a. Educational enterprise

b. Financial resource management

c. Human resource management

d. Facility and property management

e. Information management

f. Management of ancillary services 
TABLE $V$

INQUIRY QUESTIONS ON IMPORTANCE

(continued)

\section{Characteristics of Respondents}

6. District type

7. Education

8. University type
Areas of Training

6. a. Educational enterprise

b. Financial resource management

c. Human resource management

d. Facility and property management

e. Information management

f. Management of ancillary services

7. a. Educational enterprise

b. Financial resource management

c. Human resource management

d. Facility and property management

e. Information management

f. Management of ancillary services

8. a. Educational enterprise

b. Financial resource management

c. Human resource management

d. Facility and property management

e. Information management

f. Management of ancillary services

2. Is there any significant difference regarding the preferred source of training for the six general areas, that relates to the job responsibilities of respondents?

3. Is there any significant difference regarding the preferred source of training in the six general areas, that relates to the university respondents' university type?

4. Is there any significant difference regarding the importance of the six general areas, that relates to the annual budgets of respondents' districts? 
5. Is there any significant difference regarding the importance of the six general areas, that relates to the respondents' school business experience?

6. Is there any significant difference regarding the importance of the six general areas, that relates to the job responsibilities of respondents?

To analyze these questions, specific independent and dependent variables were selected for a chi-square analysis. These variables are listed in Table VI.

Following the first SYSTAT 5 analysis of the six research questions, some data entry errors were identified. These errors were removed, and a clean data base was reentered into the chi-square analysis.

In presenting the chi-square results for the research questions, the distribution with the frequency and percentage of each response noted is shown. Each figure is followed by the chi-square value, the degrees of freedom, the probability calculated by the SYSTAT 5 program, and the sample size. If the data were limited and the results suspect, that is also noted. Each question is noted as to the significance or trend indicated, but any conclusions or observations are covered in Chapter V.

In evaluating the results, a chi-square value with a low probability indicates the results from the independent variables are likely to be different. If the chi-square value results in a probability that is high, then the results from the independent variables are not likely to be different.

For purposes of this study, a difference is not considered to be significant 
TABLE VI

SIX BASIC RESEARCH QUESTIONS FORMATTED FOR ANALYSIS

Independent Variable

Dependent Variable

Research Question 1:

Location

Appropriate Training

Research Question 2:

Responsibility

Sources of Training for:

Educational Enterprise

Financial Resource Management

Human Resource Management

Facility and Property Management Information Management

Management of Ancillary Services

Research Question 3:

University Type

Sources of Training for:

Educational Enterprise

Financial Resource Management

Human Resource Management

Facility and Property Management

Information Management

Management of Ancillary Services

Research Question 4:

Budget

Importance of:

Educational Enterprise

Financial Resource Management

Human Resource Management

Facility and Property Management Information Management

Management of Ancillary Services

Research Question 5:

Importance of:

Experience

Educational Enterprise

Financial Resource Management

Human Resource Management

Facility and Property Management Information Management

Management of Ancillary Services 
TABLE VI

SIX BASIC RESEARCH QUESTIONS FORMATTED FOR ANALYSIS (continued)

Independent Variable

Research Question 6:

Responsibility

\section{Dependent Variable}

Importance of:

Educational Enterprise

Financial Resource Management Human Resource Management Facility and Property Management Information Management

Management of Ancillary Services

unless the probability is .05 or less. If the probability is in the range of .10 to .05 , it will be considered a trend but not a significant difference.

The degrees of freedom used in the analysis are based on the number of columns (c) less one times the rows $(r)$ less 1 ; or d.f. $=(c-1)(r-1)$.

\section{RESEARCH QUESTION RESULTS}

The SYSTAT 5 program analyzed each research question to determine the probability of a significant difference. Table VII summarizes the results of Research Question 1. Research Questions 2 through 6 analyze the same areas. To distinguish among Tables VIII through XXXVII, abbreviations such as $R Q 2, R Q 3, \ldots$ are used.

The research questions are summarized with reference to the respective tables for the distribution of results and the probabilities. 
Research Question 1: Is there any significant difference regarding the generally preferred source of training, that relates to the respondents' five geographic locations?

There appears to be no significant difference or trend regarding the generally preferred source of training relating to the respondents' locations (Table VII).

Research Question 2: Is there any significant difference regarding the preferred source of training for the six general areas, that relates to the respondents' job responsibilities?

Sources are identified in Tables VIII through XIII as follows: 1-College; 2-Workshop; 3-Experience; 4-Neiwork; 5-Independent study There appears to be no significant difference regarding the preferred source of training for the six general areas relating to the respondents' job responsibilities. There is a trend towards a difference indicated in the perception of Facility and Property Management.

Research Question 3: Is there any significant difference regarding the preferred source of training in the six general areas, that relates to the university respondents' university type?

Again, in Tables XIV through XIX, the sources are represented by the following values:

1-College; 2-Workshop; 3-Experience; 4-Network; 5-Independent study 
TABLE VII

\section{PREFERRED SOURCE}

(Frequencies/Percent)

Preparation Workshop Experience Iotal

Canada

U.S. East

$6 / 55$

$3 / 27$

$2 / 13$

$11 / 100$

$12 / 40$

$9 / 30$

$9 / 30$

$30 / 100$

U.S. South

$5 / 31$

$8 / 50$

$3 / 19$

$16 / 100$

U.S. Midwest

$23 / 47$

$15 / 31$

U.S. West

$14 / 38$

$16 / 43$

$11 / 22$

$49 / 100$

$7 / 19$

$37 / 100$

Total

$60 / 42$

$51 / 36$

$32 / 22$

$143 / 100$

The Pearson chi-square value for Table VII is 4.83 with 8 degrees of freedom, a probability of .78 , and a sample of 143 . No response: 108 .

TABLE VIII

EDUCATIONAL ENTERPRISE RQ2

(Frequencies/Percent)

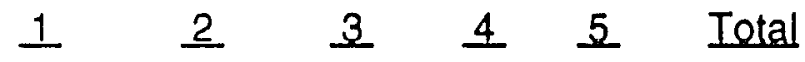

$\begin{array}{lllllll}\text { Business Administration } & 87 / 58 & 28 / 19 & 31 / 21 & 0 / 0 & 3 / 2 & 149 / 100\end{array}$

Specialist

$23 / 52 \quad \begin{array}{lllll}9 / 20 & 11 / 25 & 1 / 2 & 0 / 0 & 44 / 100\end{array}$

Superintendent

$\begin{array}{llllll}27 / 79 & 3 / 9 & 3 / 9 & 1 / 3 & 0 / 0 & 34 / 100\end{array}$

Total

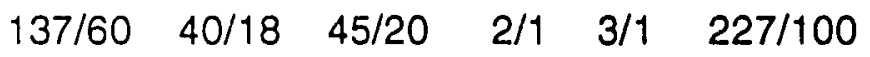

The Pearson chi-square for Table VIII is 12.66 with 8 degrees of freedom, a probability of .12, and a sample of 227 . No response: 24 . 
TABLE IX

FINANCIAL RESOURCE MANAGEMENT RQ2

(Frequencies/Percent)

$1 \quad 2 \quad 3 \quad 4 \quad$ Iotal

$\begin{array}{llllll}\text { Business Administration } & 89 / 59 & 40 / 26 & 19 / 13 & 4 / 3 & 152 / 100\end{array}$

Specialist

$25 / 57 \quad 13 / 30 \quad 5 / 11 \quad 1 / 2 \quad 44 / 100$

Superintendent

$19 / 59 \quad 8 / 25 \quad 4 / 13 \quad 1 / 3 \quad 32 / 100$

Total

$\begin{array}{lllll}133 / 58 & 61 / 27 & 28 / 12 & 6 / 3 & 228 / 100\end{array}$

The Pearson chi-square for Table IX is .29 with 6 degrees of freedom, a probability of 1.00 , and a sample of 228 . No response: 23 .

TABLE $X$

HUMAN RESOURCE MANAGEMENT RQ2

(Frequencies/Percent)

$1 \quad 2 \quad 3 \quad 4 \quad 5 \quad$ Iotal

$\begin{array}{lllllll}\text { Business Administration } \quad 60 / 40 & 55 / 36 & 30 / 20 & 6 / 4 & 0 / 0 & 151 / 100\end{array}$

Specialist

$26 / 59 \quad 11 / 25 \quad 4 / 9 \quad 2 / 5 \quad 1 / 2 \quad 44 / 100$

$\begin{array}{lllllll}\text { Superintendent } & 11 / 32 & 14 / 41 & 8 / 24 & 1 / 3 & 0 / 0 & 34 / 100\end{array}$

$\begin{array}{lllllll}\text { Total } & 97 / 42 & 80 / 35 & 42 / 18 & 9 / 4 & 1 / 0 & 229 / 100\end{array}$

The Pearson chi-square for Table $X$ is 12.75 with 8 degrees of freedom, a probability of .12, and a sample of 229 . No response: 22 . 
TABLE XI

FACILITY AND PROPERTY MANAGEMENT RQ2

(Frequencies/Percent)

$\begin{array}{lcccccc} & 1 & \underline{2} & \underline{3} & \underline{4} & \underline{5} & \text { Total } \\ \text { Business Administration } & 30 / 20 & 67 / 45 & 43 / 29 & 9 / 6 & 1 / 1 & 150 / 100 \\ \text { Specialist } & 11 / 26 & 18 / 42 & 11 / 26 & 2 / 5 & 1 / 2 & 43 / 100 \\ \text { Superintendent } & 16 / 47 & 13 / 38 & 3 / 9 & 2 / 6 & 0 / 0 & 34 / 100 \\ \text { Total } & 57 / 25 & 98 / 43 & 57 / 25 & 13 / 6 & 2 / 1 & 227 / 100\end{array}$

The Pearson chi-square for Table $\mathrm{XI}$ is 14.23 with 8 degrees of freedom, a probability of .08, and a sample of 227 . No response: 24 .

TABLE XII

INFORMATION MANAGEMENT RQ2

(Frequencies/Percent)

$1 \quad 2 \quad 3 \quad 4 \quad 5 \quad$ Iotal

$\begin{array}{lllllll}\text { Business Administration } & 63 / 42 & 49 / 33 & 22 / 15 & 14 / 9 & 2 / 1 & 150 / 100\end{array}$

Specialist

$18 / 41 \quad 14 / 32 \quad 9 / 20 \quad 1 / 2 \quad 2 / 5 \quad 44 / 100$

Superintendent

$\begin{array}{llllll}18 / 53 & 11 / 32 & 3 / 9 & 1 / 3 & 1 / 3 & 34 / 100\end{array}$

Total

$\begin{array}{llllll}99 / 43 & 74 / 32 & 34 / 15 & 16 / 7 & 5 / 2 & 228 / 100\end{array}$

The Pearson chi-square for Table XII is 7.67 with 8 degrees of freedom, a probability of .47 , and a sample of 228 . No response: 23 . 
TABLE XIII

\section{MANAGEMENT OF ANCILLARY SERVICES RQ2}

(Frequencies/Percent)

\begin{tabular}{|c|c|c|c|c|c|c|}
\hline & 1 & $\underline{2}$ & 3 & 4 & 5 & Total \\
\hline Business Admi & $22 / 15$ & $55 / 37$ & $58 / 39$ & $11 / 7$ & $2 / 1$ & \\
\hline & $8 / 19$ & $17 / 40$ & $14 / 33$ & $2 / 5$ & $2 / 5$ & $43 / 100$ \\
\hline Superintendent & $8 / 24$ & $14 / 41$ & $9 / 26$ & $3 / 9$ & $0 / 0$ & $34 / 100$ \\
\hline btal & $8 / 17$ & /3 & 136 & $16 / 7$ & $4 / 2$ & \\
\hline
\end{tabular}

The Pearson chi-square for Table XIII is 6.16 with 8 degrees of freedom, a probability of .63, and a sample of 225 . No response: 26 .

There appears to be no significant difference regarding the preferred source of training in the six general areas relating to the university type. There is a trend towards a difference indicated in the perception of Financial Resource Management, but the number of responses is limited and the results in all six areas are suspect.

Research Question 4: Is there any significant difference regarding the importance of the six general areas, that relates to the annual budgets of respondents' districts?

In this analysis, the importance values in Tables $X X$ through $X X V$ are listed below (for ease in reading the tables, 1 is designated "low" and 4 "high"): 1-Unimportant; 2-Somewhat unimportant; 3-Somewhat important; 4-Important. 
TABLE XIV

EDUCATIONAL ENTERPRISE RQ3

(Frequencies/Percent)

\begin{tabular}{lccccr} 
& 1 & $\underline{2}$ & $\underline{3}$ & $\underline{5}$ & \multicolumn{1}{c}{ Total } \\
Research & $3 / 100$ & $0 / 0$ & $0 / 0$ & $0 / 0$ & $3 / 100$ \\
Comprehensive & $8 / 80$ & $2 / 20$ & $0 / 0$ & $0 / 0$ & $10 / 100$ \\
Doctoral & $2 / 67$ & $1 / 33$ & $0 / 0$ & $0 / 0$ & $3 / 100$ \\
4-Year with Graduate & $12 / 67$ & $3 / 17$ & $2 / 11$ & $1 / 6$ & $18 / 108$ \\
Total & $25 / 74$ & $6 / 18$ & $2 / 6$ & $1 / 3$ & $34 / 100$
\end{tabular}

The Pearson chi-square for Table XIV is 4.13 with 9 degrees of freedom, a probability of .90 , and a sample of 34 . Results are suspect.

TABLE XV

FINANCIAL RESOURCE MANAGEMENT RQ3

(Frequencies/Percent)

$1 \quad 2 \quad 3 \quad 4 \quad$ Total

Research

Comprehensive

$1 / 33$

$2 / 67$

$0 / 0$

$0 / 0 \quad 3 / 100$

$\begin{array}{lllll}10 / 100 & 0 / 0 & 0 / 0 & 0 / 0 & 10 / 100\end{array}$

Doctoral

$1 / 33$

$2 / 67$

$0 / 0 \quad 0 / 0 \quad 3 / 100$

4-Year with Graduate

$14 / 77$

$2 / 11$

$2 / 11$

$1 / 5 \quad 19 / 100$

Total

$26 / 74$

$6 / 17 \quad 2 / 6$

$1 / 3 \quad 35 / 100$

The Pearson chi-square for Table XV is 15.56 with 9 degrees of freedom, a probability of .08 , and a sample of 35 . Results are suspect. 
TABLE XVI

HUMAN RESOURCE MANAGEMENT RQ3

(Frequencies/Percent)

$1 \quad 2 \quad 3 \quad 5 \quad$ Total

Research

$\begin{array}{lllll}1 / 33 & 2 / 67 & 0 / 0 & 0 / 0 & 3 / 100\end{array}$

$\begin{array}{lllll}6 / 60 & 2 / 20 & 2 / 20 & 0 / 0 & 10 / 100\end{array}$

$\begin{array}{lrllll}\text { Doctoral } & 1 / 33 & 2 / 67 & 0 / 0 & 0 / 0 & 3 / 100\end{array}$

$\begin{array}{llllll}4-Y e a r & \text { with Graduate } \quad 13 / 68 & 1 / 5 & 4 / 21 & 1 / 5 & 19 / 100\end{array}$

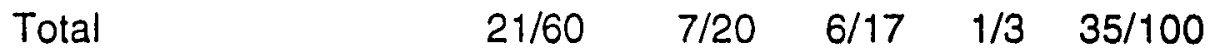

The Pearson chi-square for Table XVI is 11.62 with 9 degrees of freedom, a probability of .24 , and a sample of 35 . Results are suspect.

TABLE XVII

FACILITY AND PROPERTY MANAGEMENT RQ3

(Frequencies/Percent)

$1 \quad 2 \quad 3 \quad 5 \quad$ Iotal

$\begin{array}{llllll}\text { Research } & 0 / 0 & 3 / 100 & 0 / 0 & 0 / 0 & 3 / 100\end{array}$

$\begin{array}{llllll}\text { Comprehensive } & 5 / 50 & 1 / 10 & 4 / 40 & 0 / 0 & 10 / 100\end{array}$

$\begin{array}{llllll}\text { Doctoral } & 1 / 33 & 2 / 67 & 0 / 0 & 0 / 0 & 3 / 100\end{array}$

$\begin{array}{llllll}4-Y e a r & \text { with Graduate } \quad 8 / 44 & 4 / 22 & 5 / 28 & 1 / 6 & 18 / 100\end{array}$

$\begin{array}{llllll}\text { Total } & 14 / 41 & 10 / 29 & 9 / 26 & 1 / 3 & 34 / 100\end{array}$

The Pearson chi-square for Table XVII is 12.79 with 9 degrees of freedom, a probability of .17, and a sample of 34 . Results are suspect. 
TABLE XVIII

INFORMATION MANAGEMENT RQ3

(Frequencies/Percent)

Research

$1 \quad 2 \quad 3 \quad 4 \quad 5 \quad$ Total

Comprehensive

$\begin{array}{llllll}1 / 33 & 2 / 67 & 0 / 0 & 0 / 0 & 0 / 0 & 3 / 100\end{array}$

$\begin{array}{llllll}6 / 60 & 3 / 30 & 0 / 0 & 1 / 10 & 0 / 0 & 10 / 100\end{array}$

Doctoral

$\begin{array}{llllll}1 / 33 & 1 / 33 & 0 / 0 & 1 / 33 & 0 / 0 & 3 / 100\end{array}$

$\begin{array}{llllll}4 \text { Years with Graduate } \quad 10 / 57 & 6 / 32 & 1 / 5 & 0 / 0 & 2 / 11 & 19 / 100\end{array}$

Total

$\begin{array}{llllll}18 / 51 & 12 / 34 & 1 / 3 & 2 / 6 & 2 / 6 & 35 / 100\end{array}$

The Pearson chi-square for Table XVIII is 9.65 with 12 degrees of freedom, a probability of .65 , and a sample of 35 . Results are suspect.

TABLE XIX

MANAGEMENT OF ANCILLARY SERVICES RQ3

(Frequencies/Percent)

$1 \quad 2 \quad 3 \quad \quad 4 \quad \underline{5} \quad$ Total

Research

$0 / 0 \quad 2 / 67 \quad 1 / 33 \quad 0 / 0 \quad 0 / 0 \quad 3 / 100$

$\begin{array}{lllllll}\text { Comprehensive } & 4 / 40 & 1 / 10 & 5 / 50 & 0 / 0 & 0 / 0 & 10 / 100\end{array}$

Doctoral

$\begin{array}{llllll}1 / 33 & 1 / 33 & 0 / 0 & 1 / 33 & 0 / 0 & 3 / 100\end{array}$

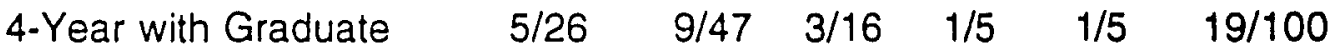

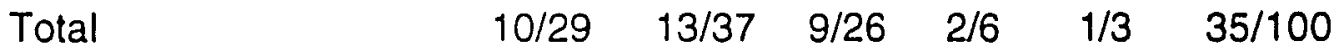

The Pearson chi-square for Table XIX is 14.06 with 12 degrees of freedom, a probability of .30 , and a sample of 35 . Results are suspect. 
TABLE XX

\section{EDUCATIONAL ENTERPRISE RQ4}

(Frequencies/Percent)

$\begin{array}{lccccc} & 1 \text { (low) } & 2 & \underline{3} & \underline{4} \text { (high) } & \text { Total } \\ \text { Low Budget } & 5 / 7 & 5 / 7 & 27 / 39 & 33 / 47 & 70 / 100 \\ \text { Medium Budget } & 3 / 3 & 9 / 9 & 38 / 39 & 47 / 48 & 97 / 100 \\ \text { High Budget } & 0 / 0 & 3 / 6 & 23 / 44 & 26 / 50 & 52 / 100 \\ \text { Total } & 8 / 4 & 17 / 8 & 88 / 40 & 106 / 48 & 219 / 100\end{array}$

The Pearson chi-square for Table $X X$ is 5.24 with 6 degrees of freedom, a probability of .51 , and a sample of 219 . No response: 32 .

TABLE XXI

FINANCIAL RESOURCE MANAGEMENT RQ4

(Frequencies/Percent)

$\underline{1(\text { low) } 2} \quad \underline{3} \quad \underline{4 \text { (high) }}$ Iotal

$\begin{array}{llllll}\text { Low Budget } & 3 / 4 & 1 / 1 & 6 / 8 & 6186 & 71 / 100\end{array}$

$\begin{array}{llllll}\text { Medium Budget } & 5 / 5 & 1 / 1 & 7 / 7 & 87 / 87 & 100 / 100\end{array}$

$\begin{array}{llllll}\text { High Budget } & 1 / 2 & 2 / 4 & 5 / 9 & 44 / 85 & 52 / 100\end{array}$

$\begin{array}{llllll}\text { Total } & 9 / 4 & 4 / 2 & 18 / 8 & 192 / 86 & 223 / 100\end{array}$

The Pearson chi-square for Table XXI is 2.774 with 6 degrees of freedom, a probability of .84 , and a sample of 223 . No response: 28 . 
TABLE XXII

HUMAN RESOURCE MANAGEMENT RQ4

(Frequencies/Percent)

\begin{tabular}{lccccc} 
& 1 (low) & 2 & $\underline{3}$ & $\underline{4}$ (high) & \multicolumn{1}{c}{ Total } \\
Low Budget & $2 / 3$ & $7 / 10$ & $24 / 34$ & $38 / 53$ & $71 / 100$ \\
Medium Budget & $3 / 3$ & $6 / 6$ & $25 / 25$ & $66 / 66$ & $100 / 100$ \\
High Budget & $0 / 0$ & $3 / 6$ & $15 / 29$ & $34 / 65$ & $52 / 100$ \\
Total & $5 / 2$ & $16 / 7$ & $64 / 29$ & $138 / 62$ & $223 / 100$
\end{tabular}

The Pearson chi-square for Table XXII is 4.88 with 6 degrees of freedom, a probability of .56, and a sample of 223 . No response: 28 .

TABLE XXIII

FACILITY AND PROPERTY MANAGEMENT RQ4

(Frequencies/Percent)

1 (low) $2 \quad \underline{3} \quad \underline{4 \text { (high) }} \quad \underline{\text { Total }}$

$\begin{array}{lrrrrr}\text { Low Budget } & 2 / 3 & 4 / 6 & 25 / 35 & 41 / 57 & 72 / 100 \\ \text { Medium Budget } & 3 / 3 & 3 / 3 & 39 / 39 & 55 / 55 & 100 / 100 \\ \text { High Budget } & 0 / 0 & 1 / 2 & 22 / 42 & 29 / 56 & 52 / 100 \\ & & & & & \\ \text { Total } & 5 / 2 & 8 / 4 & 86 / 38 & 125 / 56 & 224 / 100\end{array}$

The Pearson chi-square for Table XXIII is 3.30 with 6 degrees of freedom, a probability of .77, and a sample of 224 . No response: 27. 
TABLE XXIV

\section{INFORMATION MANAGEMENT RQ4}

\begin{tabular}{lrrrrr} 
& \multicolumn{5}{c}{ (Frequencies/Percent) } \\
& 1 (low) & $\underline{2}$ & $\underline{3}$ & $\underline{4 \text { (high) }}$ & \multicolumn{1}{c}{ Total } \\
Low Budget & $2 / 3$ & $7 / 10$ & $24 / 33$ & $39 / 54$ & $72 / 100$ \\
Medium Budget & $4 / 4$ & $2 / 2$ & $34 / 34$ & $60 / 60$ & $100 / 100$ \\
High Budget & $1 / 2$ & $2 / 4$ & $19 / 37$ & $30 / 58$ & $52 / 100$ \\
Total & $7 / 3$ & $11 / 5$ & $77 / 34$ & $129 / 58$ & $224 / 100$
\end{tabular}

The Pearson chi-square for Table XXIV is 6.10 with 6 degrees of freedom, a probability of .41 , and a sample of 224 . No response: 27 .

\section{TABLE XXV}

MANAGEMENT OF ANCILLARY SERVICES RQ4

(Frequencies/Percent)

1 (low) $2 \quad 3 \quad \underline{4}$ (high) Total

$\begin{array}{llllll}\text { Low Budget } & 3 / 4 & 8 / 11 & 33 / 47 & 26 / 37 & 70 / 100\end{array}$

$\begin{array}{llllll}\text { Medium Budget } \quad 4 / 4 & 6 / 6 & 52 / 53 & 36 / 37 & 98 / 100\end{array}$

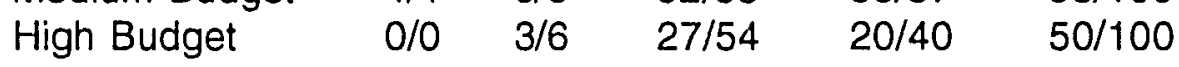

$\begin{array}{llllll}\text { Total } & 7 / 3 & 17 / 8 & 112 / 51 & 82 / 38 & 218 / 100\end{array}$

The Pearson chi-square for Table XXV is 4.30 with 6 degrees of freedom, a probability of .64, and a sample of 218 . No response: 33 .

There appears to be no significant difference regarding the importance of the six general areas relating to the respondents' district budgets. 
Research Question 5: Is there any significant difference regarding the importance of the six general areas, that relates to respondents' school business experience?

The importance values for Tables XXVI through $X X X I$ are as follows: 1-Unimportant (low); 2-Somewhat unimportant; 3-Somewhat important; 4-Important (high).

There appears to be no significant difference regarding the importance of the six general areas relating to the respondents' school business experience.

TABLE XXVI

EDUCATIONAL ENTERPRISE RQ5

(Frequencies/Percent)

1 (low) $2 \quad 3 \quad \underline{4}$ (high) Total

0.5 Years

6-10 Years

10-plus Years

$\begin{array}{lllll}3 / 7 & 4 / 10 & 19 / 45 & 16 / 38 & 42 / 100\end{array}$

$\begin{array}{lllll}1 / 2 & 3 / 5 & 25 / 45 & 27 / 48 & 56 / 100\end{array}$

$\begin{array}{lllll}4 / 3 & 10 / 8 & 44 / 36 & 64 / 52 & 122 / 100\end{array}$

Total

$\begin{array}{lllll}8 / 4 & 17 / 8 & 88 / 40 & 107 / 49 & 220 / 100\end{array}$

The Pearson chi-square for Table XXVI is 5.00 with 6 degrees of freedom, a probability of .54, and a sample of 220 . No response: 31 . 
TABLE XXVII

FINANCIAL RESOURCE MANAGEMENT RQ5

(Frequencies/Percent)

1 (low) $2 \quad 3 \quad 4$ (high) Total

$0-5$ Years

$\begin{array}{lllll}3 / 7 & 0 / 0 & 5 / 12 & 34 / 81 & 42 / 100\end{array}$

6-10 Years

$0 / 0 \quad 2 / 3 \quad 7 / 12$

$50 / 85 \quad 59 / 100$

10-plus Years

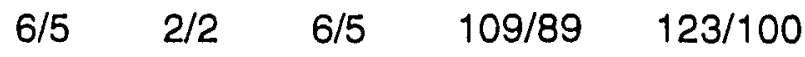

Total

$\begin{array}{lllll}9 / 4 & 4 / 2 & 18 / 8 & 193 / 86 & 224 / 100\end{array}$

The Pearson chi-square for Table XXVII is 8.85 with 6 degrees of freedom, a probability of .18, and a sample of 224 . No response: 27.

TABLE XXVIII

HUMAN RESOURCE MANAGEMENT RQ5

(Frequencies/Percent)

1 (low) $2 \quad 3 \quad 4$ (high) Total

$0-5$ Years

$1 / 2 \quad 4 / 10 \quad 14 / 34 \quad 22 / 54 \quad 41 / 100$

6-10 Years

$0 / 0 \quad 5 / 8 \quad 19 / 32 \quad 35 / 59 \quad 59 / 100$

10-plus Years

$\begin{array}{lllll}4 / 3 & 7 / 6 & 31 / 25 & 82 / 66 & 124 / 100\end{array}$

$\begin{array}{llllll}\text { Total } & 5 / 2 & 16 / 7 & 64 / 29 & 139 / 62 & 224 / 100\end{array}$

The Pearson chi-square for Table XXVIII is 4.94 with 6 degrees of freedom, a probability of .55, and a sample of 224 . No response: 27. 
TABLE XXIX

FACILITY AND PROPERTY MANAGEMENT RQ5

\begin{tabular}{lccccc}
\multicolumn{7}{c}{ (Frequencies/Percent) } \\
& 1 (low) & 2 & 3 & $\underline{4}$ (high) & Iotal \\
0-5 Years & $2 / 5$ & $0 / 0$ & $18 / 43$ & $22 / 52$ & $42 / 100$ \\
6-10 Years & $0 / 0$ & $5 / 8$ & $23 / 39$ & $31 / 53$ & $59 / 100$ \\
10-plus Years & $3 / 2$ & $3 / 2$ & $45 / 36$ & $73 / 59$ & $124 / 100$ \\
Total & $5 / 2$ & $8 / 4$ & $86 / 38$ & $126 / 56$ & $225 / 100$ \\
The Pearson chi-square for Table XXIX is 9.28 with 6 degrees of \\
freedom, a probability of .16, and a sample of 225. No response: 26.
\end{tabular}

TABLE XXX

INFORMATION MANAGEMENT RQ5

(Frequencies/Percent)

1 (low) $2 \quad 3 \quad 4$ (high) Total

$\begin{array}{lrrrrr}0-5 \text { Years } & 2 / 5 & 2 / 5 & 12 / 39 & 26 / 62 & 42 / 100 \\ \text { 6-10 Years } & 0 / 0 & 2 / 3 & 22 / 37 & 35 / 59 & 59 / 100 \\ \text { 10-plus Years } & 5 / 4 & 7 / 6 & 43 / 35 & 69 / 56 & 124 / 100 \\ \text { Total } & 7 / 2 & 11 / 5 & 77 / 34 & 130 / 58 & 225 / 100\end{array}$

The Pearson chi-square for Table XXVI is 3.77 with 6 degrees of freedom, a probability of .71, and a sample of 225 . No response: 26 . 
TABLE XXXI

MANAGEMENT OF ANCILLARY SERVICES RQ5

(Frequencies/Percent)

\begin{tabular}{lccccc} 
& 1 & 2 & $\underline{3}$ & $\underline{4}$ & \multicolumn{1}{c}{ Total } \\
0-5 Years & $3 / 7$ & $5 / 2$ & $23 / 56$ & $10 / 24$ & $41 / 100$ \\
6-10 Years & $1 / 2$ & $5 / 9$ & $25 / 43$ & $27 / 47$ & $58 / 100$ \\
10-plus Years & $3 / 3$ & $7 / 6$ & $64 / 53$ & $46 / 35$ & $120 / 100$ \\
Total & $7 / 3$ & $17 / 8$ & $112 / 51$ & $83 / 38$ & $219 / 100$
\end{tabular}

The Pearson chi-square for Table XXXI is 8.59 with 6 degrees of freedom, a probability of .20, and a sample of 219 . No response: 32 .

Research Question 6: Is there any significant difference regarding the importance of the six general areas, that relates to respondents' job responsibilities?

Again, the importance values for Tables XXXII through XXXVII are as follows:

1-Unimportant (low); 2-Somewhat unimportant; 3-Somewhat important;

4-Important (high).

There appears to be no significant difference regarding the importance of the six general areas relating to the respondents' job responsibilities. There is a trend towards a difference indicated in the perception of Human Resource Management. 
TABLE XXXII

EDUCATIONAL ENTERPRISE RQ6

(Frequencies/Percent)

1 (low) $2 \quad 3 \quad \underline{4}$ (high) Total

$\begin{array}{llllll}\text { Business Administrator } & 5 / 3 & 11 / 7 & 58 / 39 & 73 / 50 & 147 / 100\end{array}$

$\begin{array}{llllll}\text { Specialist } & 0 / 0 & 2 / 5 & 18 / 42 & 23 / 53 & 43 / 100\end{array}$

$\begin{array}{llllll}\text { Superintendent } & 3 / 9 & 3 / 9 & 12 / 35 & 16 / 47 & 34 / 100\end{array}$

$\begin{array}{llllll}\text { Total } & 8 / 4 & 16 / 7 & 88 / 39 & 112 / 50 & 224 / 100\end{array}$

The Pearson chi-square for Table XXXII is 5.08 with 6 degrees of freedom, a probability of .53, and a sample of 224 . No response: 27.

TABLE XXXIII

FINANCIAL RESOURCE MANAGEMENT RQ6

(Frequencies/Percent)

1 (low) $2 \quad 3 \quad \underline{4}$ (high) Total

$\begin{array}{llllll}\text { Business Administrator } & 5 / 3 & 4 / 3 & 16 / 11 & 126 / 83 & 151 / 100\end{array}$

$\begin{array}{llllll}\text { Specialist } & 1 / 2 & 0 / 0 & 3 / 7 & 41 / 91 & 45 / 100\end{array}$

$\begin{array}{llllll}\text { Superintendent } & 2 / 6 & 0 / 0 & 1 / 3 & 29 / 91 & 32 / 100\end{array}$

$\begin{array}{llllll}\text { Total } & 8 / 4 & 4 / 2 & 20 / 9 & 196 / 86 & 228 / 100\end{array}$

The Pearson chi-square for Table XXXIII is 5.25 with 6 degrees of freedom, a probability of .51, and a sample of 228. No response: 23. 
TABLE XXXIV

\section{HUMAN RESOURCE MANAGEMENT RQ6}

(Frequencies/Percent)

\begin{tabular}{|c|c|c|c|c|c|}
\hline & 1 (low) & 2 & 3 & 4 (high) & Total \\
\hline rator & $2 / 1$ & $13 / 7$ & $48 / 32$ & $87 / 58$ & 150 \\
\hline & $0 / 0$ & $2 / 4$ & $8 / 1$ & & $45 / 100$ \\
\hline Superintendent & $2 / 6$ & $1 / 3$ & $11 / 33$ & $19 / 58$ & $33 / 100$ \\
\hline tal & $4 / 2$ & $16 / 7$ & $67 / 29$ & $41 / 62$ & \\
\hline
\end{tabular}

The Pearson chi-square for Table XXXIV is 11.07 with 6 degrees of freedom, a probability of .09 , and a sample of 228 . No response: 23 .

TABLE XXXV

FACILITY AND PROPERTY MANAGEMENT RQ6

(Frequencies/Percent)

1 (low) $2 \quad 3 \quad 4$ (high) Iotal

$\begin{array}{llllll}\text { Business Administrator } & 4 / 3 & 5 / 3 & 59 / 39 & 83 / 55 & 151 / 100\end{array}$

\begin{tabular}{l|lllll} 
Specialist & $0 / 0$ & $1 / 2$ & $16 / 36$ & $27 / 61$ & $44 / 100$
\end{tabular}

$\begin{array}{llllll}\text { Superintendent } & 11 / 3 & 1 / 3 & 14 / 42 & 17 / 52 & 33 / 100\end{array}$

$\begin{array}{llllll}\text { Total } & 5 / 2 & 7 / 3 & 89 / 39 & 127 / 56 & 228 / 100\end{array}$

The Pearson chi-square for Table XXXV is 1.88 with 6 degrees of freedom, a probability of .93, and a sample of 228 . No response: 23. 
TABLE XXXVI

INFORMATION MANAGEMENT RQ6

(Frequencies/Percent)

\begin{tabular}{lccccc} 
& 1 (low) & 2 & $\underline{3}$ & $\underline{4}$ (high) & Total \\
\cline { 2 - 6 } & & & & & \\
Business Administrator & $4 / 3$ & $6 / 4$ & $53 / 35$ & $88 / 58$ & $151 / 100$ \\
Specialist & $1 / 2$ & $1 / 2$ & $16 / 36$ & $27 / 60$ & $45 / 100$ \\
Superintendent & $2 / 6$ & $3 / 9$ & $12 / 36$ & $16 / 48$ & $33 / 100$ \\
Total & $7 / 3$ & $10 / 4$ & $81 / 35$ & $131 / 57$ & $229 / 100$
\end{tabular}

The Pearson chi-square for Table XXXVI is 3.92 with 6 degrees of freedom, a probability of .69, and a sample of 229. No response: 22.

TABLE XXXVII

MANAGEMENT OF ANCILLARY SERVICES RQ6

(Frequencies/Percent)

1 (low) $2 \quad 3 \quad 4$ (high) Total

$\begin{array}{lrrrrr}\text { Business Administrator } & 4 / 3 & 12 / 8 & 80 / 54 & 51 / 35 & 147 / 100 \\ \text { Specialist } & 1 / 2 & 2 / 5 & 17 / 40 & 23 / 53 & 43 / 100 \\ \text { Superintendent } & 2 / 6 & 1 / 3 & 19 / 58 & 11 / 33 & 33 / 100\end{array}$

$\begin{array}{llllll}\text { Total } & 7 / 3 & 15 / 17 & 116 / 52 & 85 / 38 & 223 / 100\end{array}$

The Pearson chi-square for Table XXXVII is 7.43 with 6 degrees of freedom, a probability of .28 , and a sample of 223 . No response: 28

\section{INQUIRY QUESTION RESULTS}

The results of the first eight inquiry questions (Table $\mathrm{V}$ ) are summarized in Tables XXXVIII through XLV. The same information is included, but in a shorter format than that used for the research questions. The statistical 
information is summarized by the degrees of freedom, sample size, chi-square value, and probability, for example: chi-square $(6, \underline{N}=217)=3.73, p=.71)$.

For Inquiry Question 1, there appears to be no significant difference in the perceived importance of the selected area of training relating to the respondents' job responsibilities. There is a trend indicated in the perception of the importance of supply and equipment management.

Again, the importance values for Table XXXVIII are as follows: 1-Unimportant (low); 2-Somewhat unimportant; 3-Somewhat important; 4-Important (high).

A review of Inquiry Question 2, as shown inTable XXXIX, indicates there is no significant difference in the importance of Health and Safety relating to the budget of the respondents' districts. The importance values are the same as for Table XXXVIII.

Inquiry Question 3 results are displayed in Table XL. There appears to be a significant difference as to the perception of the importance of Human Resource Management relating to the respondents' ages. The importance values are the same as for previous tables.

The results for Inquiry Question 4 are displayed in Table XLI. There appears to be a significant difference as to the perception of the importance of Human Resource Management relating to the respondents' gender. The importance values assigned to the areas of training remain the same as for the three previous tables. 
TABLE XXXVIII

INQUIRY QUESTION 1 RESULTS

(Frequencies/Percent)

Responsibility by Foundations of Teaching and Learning

$\begin{array}{lccccc} & 1 \text { (low) } & \underline{2} & \underline{3} & \underline{4 \text { (high) }} & \text { Total } \\ \text { Business Administrator } & 12 / 8 & 37 / 26 & 53 / 37 & 42 / 29 & 144 / 100 \\ \text { Specialist } & 3 / 8 & 11 / 28 & 12 / 31 & 13 / 33 & 39 / 100 \\ \text { Superintendent } & 0 / 0 & 10 / 29 & 14 / 41 & 10 / 29 & 34 / 100 \\ \text { Total } & 15 / 7 & 58 / 27 & 79 / 36 & 65 / 30 & 217 / 100\end{array}$

Chi-square $(6, \underline{N}=217)=3.73, p=.71$. No response: 34 .

Responsibility by Staff Development

\begin{tabular}{lccccc} 
& 1 (low) & 2 & 3 & $\underline{4 \text { (high) }}$ & Total \\
\cline { 2 - 5 } & & & & & \\
Business Administrator & $5 / 3$ & $12 / 8$ & $74 / 50$ & $56 / 38$ & $147 / 100$ \\
Specialist & $1 / 2$ & $2 / 5$ & $24 / 57$ & $15 / 36$ & $42 / 100$ \\
Superintendent & $2 / 6$ & $6 / 18$ & $15 / 45$ & $10 / 30$ & $33 / 100$ \\
Total & $8 / 4$ & $20 / 9$ & $113 / 51$ & $81 / 36$ & $222 / 100$
\end{tabular}

Chi-square $(6, \underline{N}=222)=5.76, p=.45$. No response: 29 .

Responsibility by Supplies and Equipment Management

1 (low) $2 \quad 3 \quad 4$ (high) Total

Business Administrator $\quad 2 / 1 \quad 19 / 13 \quad 77 / 51 \quad 52 / 35 \quad 150 / 100$ $\begin{array}{llllll}\text { Specialist } & 0 / 0 & 4 / 10 & 21 / 53 & 15 / 38 & 40 / 100\end{array}$ $\begin{array}{llllll}\text { Superintendent } & 3 / 9 & 2 / 6 & 13 / 38 & 16 / 47 & 34 / 100\end{array}$

$\begin{array}{llllll}\text { Total } & 5 / 2 & 25 / 11 & 111 / 50 & 83 / 37 & 224 / 100\end{array}$

Chi-square $(6, \underline{N}=224)=11.45, p=.08$. No response: 27 . 
TABLE XXXVIII

INQUIRY QUESTION 1 RESULTS

(continued)

(Frequencies/Percent)

Responsibility by Real-Estate Management

\begin{tabular}{lcrrrr} 
& 1 (llow) & $\underline{2}$ & $\underline{3}$ & $\underline{4}$ (high) & Total \\
\cline { 2 - 5 } & & & & & \\
Business Administrator & $9 / 7$ & $43 / 31$ & $56 / 41$ & $29 / 21$ & $137 / 100$ \\
Specialist & $3 / 8$ & $7 / 18$ & $18 / 47$ & $10 / 26$ & $38 / 100$ \\
Superintendent & $2 / 6$ & $13 / 38$ & $14 / 41$ & $5 / 15$ & $34 / 100$ \\
Total & $14 / 7$ & $63 / 30$ & $88 / 42$ & $44 / 21$ & $209 / 100$
\end{tabular}

Chi-square $(6, \underline{N}=209)=4.12, p=.66$. No response: 42 .

Responsibility by Program Evaluation, Research, and Analysis

1 (low) $2 \quad 3 \quad \underline{4 \text { (high) }} \quad \underline{T} \quad$

$\begin{array}{llllll}\text { Business Administrator } & 4 / 3 & 14 / 10 & 67 / 47 & 58 / 41 & 143 / 100\end{array}$

$\begin{array}{llllll}\text { Specialist } & 3 / 7 & 6 / 14 & 16 / 38 & 17 / 40 & 42 / 100\end{array}$

$\begin{array}{llllll}\text { Superintendent } & 2 / 6 & 5 / 15 & 18 / 53 & 9 / 26 & 34 / 100\end{array}$

$\begin{array}{llllll}\text { Total } & 9 / 4 & 25 / 11 & 101 / 46 & 84 / 38 & 219 / 100\end{array}$

Chi-square $(6, \underline{N}=219)=5.19, p=.52$. No response: 32 .

As shown in Table XLII, results for Inquiry Question 5 appear to show no significant difference in the perception of the importance of the areas of training relating to the respondents' locations.

The importance values assigned to the areas of training continue to be:

1-Unimportant (low); 2-Somewhat unimportant; 3-Somewhat important;

4-Important (high). 
TABLE XXXIX

INQUIRY QUESTION 2 RESULTS

(Frequencies/Percent)

Budget by Health and Safety

$\begin{array}{lcrrrl} & 1 \text { (low) } & \underline{2} & \underline{3} & \underline{4 \text { (high) }} & \text { Total } \\ \text { Low Budget } & 3 / 4 & 5 / 7 & 28 / 40 & 34 / 49 & 70 / 100 \\ \text { Medium Budget } & 4 / 4 & 6 / 6 & 38 / 40 & 46 / 49 & 94 / 100 \\ \text { High Budget } & 0 / 0 & 5 / 10 & 32 / 62 & 15 / 29 & 52 / 100 \\ \text { Total } & 7 / 3 & 16 / 7 & 98 / 45 & 95 / 44 & 216 / 100\end{array}$

Chi-square $(6, \underline{N}=216)=10.22, p=.12$. No response: 35 .

TABLE XL

INQUIRY QUESTION 3 RESULTS

(Frequencies/Percent)

Age by Educational Enterprise

1 (low) $22 \quad 3 \quad \underline{4}$ (high) Total

$\begin{array}{lllrrr}0-29 & 0 / 0 & 0 / 0 & 3 / 75 & 1 / 25 & 4 / 100 \\ 30-39 & 0 / 0 & 4 / 10 & 15 / 36 & 23 / 55 & 42 / 100 \\ 40-49 & 4 / 4 & 4 / 4 & 41 / 42 & 49 / 50 & 98 / 100 \\ 50-59 & 2 / 3 & 8 / 10 & 27 / 35 & 41 / 53 & 78 / 100 \\ 60 \text {-plus } & 2 / 10 & 2 / 10 & 3 / 15 & 13 / 65 & 20 / 100\end{array}$

$\begin{array}{llllll}\text { TOTAL } & 8 / 3 & 18 / 7 & 89 / 37 & 127 / 53 & 242 / 100\end{array}$

Chi-square $(12, \underline{N}=242)=13.9, p=.31$. No response: 9 . 
TABLE XL

INQUIRY QUESTION 3 RESULTS

(continued)

(Frequencies/Percent)

Age by Financial Resource Management

1 (low) $\quad 2 \quad \underline{3} \quad \underline{4}$ (high) Total

$\begin{array}{lllrrr}0-29 & 0 / 0 & 0 / 0 & 1 / 25 & 3 / 75 & 4 / 100 \\ 30-39 & 1 / 2 & 1 / 2 & 5 / 11 & 38 / 84 & 45 / 100 \\ 40-49 & 2 / 2 & 2 / 2 & 7 / 7 & 88 / 89 & 99 / 100 \\ 50-59 & 3 / 4 & 1 / 1 & 7 / 9 & 67 / 86 & 78 / 100 \\ \text { 60-plus } & 3 / 15 & 0 / 0 & 1 / 5 & 16 / 80 & 20 / 100 \\ & & & & & \\ \text { TOTAL } & 9 / 4 & 4 / 2 & 21 / 9 & 212 / 86 & 246 / 100\end{array}$

Chi-square $(12, \underline{N}=246)=11.23, p=.51$. No response: 5 .

Age by Human Resource Management

$\begin{array}{lccrrr} & \underline{1} \text { (low) } & \underline{2} & \underline{3} & \underline{4 \text { (high) }} & \text { Total } \\ \text { 0-29 } & 0 / 0 & 0 / 0 & 2 / 50 & 2 / 50 & 4 / 100 \\ 30-39 & 0 / 0 & 3 / 7 & 12 / 27 & 30 / 67 & 45 / 100 \\ 40-49 & 1 / 1 & 9 / 9 & 27 / 27 & 62 / 63 & 99 / 100 \\ 50-59 & 1 / 1 & 4 / 5 & 23 / 29 & 50 / 64 & 78 / 100 \\ 60-\text { plus } & 3 / 15 & 0 / 0 & 3 / 15 & 14 / 70 & 20 / 100 \\ \text { TOTAL } & 5 / 2 & 16 / 7 & 67 / 27 & 158 / 64 & 246 / 100 \\ \text { Chi-square }(12, \underline{N}=246)=23.40, p=.03 . & \text { No response: } 5 .\end{array}$


TABLE XL

INQUIRY QUESTION 3 RESULTS

(continued)

(Frequencies/Percent)

Age by Facility and Property Management

1 (low) $2 \quad \underline{3} \quad 4$ (high) Total

$\begin{array}{llllll}0-29 & 0 / 0 & 0 / 0 & 2 / 50 & 2 / 50 & 4 / 100\end{array}$

$\begin{array}{llllll}30-39 & 0 / 0 & 1 / 2 & 20 / 44 & 24 / 53 & 45 / 100\end{array}$

$\begin{array}{llllll}40-49 & 1 / 1 & 4 / 4 & 41 / 41 & 54 / 54 & 100 / 100\end{array}$

$\begin{array}{llllll}50-59 & 2 / 3 & 1 / 1 & 26 / 33 & 49 / 63 & 78 / 100\end{array}$

$\begin{array}{llllll}60 \text {-plus } & 2 / 11 & 2 / 11 & 3 / 16 & 12 / 63 & 19 / 100\end{array}$

$\begin{array}{llllll}\text { TOTAL } & 5 / 2 & 8 / 3 & 92 / 37 & 141 / 57 & 246 / 100\end{array}$

Chi-square $(12, \underline{N}=246)=17.55, p=.13$. No response: 5 .

Age by Information Management

\begin{tabular}{|c|c|c|c|c|c|}
\hline & 1 (low) & $\underline{2}$ & 3 & 4 (high) & Total \\
\hline $0-29$ & $0 / 0$ & $0 / 0$ & $2 / 50$ & $2 / 50$ & $4 / 100$ \\
\hline 30-39 & $1 / 2$ & $1 / 2$ & $18 / 40$ & $25 / 56$ & $45 / 100$ \\
\hline $40-49$ & $2 / 2$ & $5 / 5$ & $31 / 31$ & $62 / 62$ & $100 / 100$ \\
\hline $50-59$ & $2 / 3$ & $4 / 5$ & $29 / 37$ & $43 / 55$ & $78 / 100$ \\
\hline \multirow{2}{*}{60 -plus } & $2 / 10$ & $1 / 5$ & $6 / 30$ & $11 / 55$ & $20 / 100$ \\
\hline & 1 & $\underline{2}$ & 3 & 4 & Total \\
\hline TAL & $7 / 3$ & $11 / 4$ & $86 / 35$ & $143 / 58$ & $247 / 100$ \\
\hline
\end{tabular}

Chi-square $(12, \underline{N}=247)=6.70, p=.88$. No response: 4 . 
TABLE XL

INQUIRY QUESTION 3 RESULTS

(continued)

(Frequencies/Percent)

Age by Management of Ancillary Services

\begin{tabular}{lccrrr} 
& $\underline{1 \text { (low) }}$ & $\underline{2}$ & $\underline{3}$ & $\underline{4}$ (high) & \multicolumn{1}{c}{ Total } \\
$0-29$ & $0 / 0$ & $1 / 25$ & $2 / 50$ & $1 / 25$ & $4 / 100$ \\
$30-39$ & $2 / 5$ & $4 / 9$ & $22 / 51$ & $15 / 35$ & $43 / 100$ \\
$40-49$ & $2 / 2$ & $6 / 6$ & $49 / 50$ & $41 / 42$ & $98 / 100$ \\
$50-59$ & $1 / 1$ & $5 / 7$ & $37 / 49$ & $32 / 43$ & $75 / 100$ \\
60-plus & $2 / 10$ & $1 / 5$ & $11 / 55$ & $6 / 30$ & $20 / 100$ \\
TOTAL & $7 / 3$ & $17 / 7$ & $121 / 50$ & $95 / 40$ & $240 / 100$
\end{tabular}

Chi-square $(12, \underline{N}=240)=8.62, p=.73$. No response: 11 .

TABLE XLI

INQUIRY QUESTION 4 RESULTS

(Frequencies/Percent)

Gender by Educational Enterprise

1 (low) $2 \quad 3 \quad \underline{4}$ (high) Total

$\begin{array}{lrrrrr}\text { Female } & 1 / 2 & 3 / 6 & 19 / 36 & 30 / 57 & 53 / 100 \\ \text { Male } & 7 / 4 & 15 / 8 & 70 / 37 & 96 / 51 & 188 / 100\end{array}$

$\begin{array}{llllll}\text { TOTAL } & 8 / 3 & 18 / 7 & 89 / 37 & 126 / 52 & 241 / 100\end{array}$

Chi-square $(3, \underline{N}=241)=.98, p=.81$. No response: 10 . 
TABLE XLI

INQUIRY QUESTION 4 RESULTS

(continued)

(Frequencies/Percent)

Gender by Financial Resource Management

$\begin{array}{llllll} & 1 \text { (low) } & 2 & \underline{3} & \underline{4 \text { (high) }} & \text { Total } \\ \text { Female } & 0 / 0 & 2 / 4 & 3 / 5 & 51 / 91 & 56 / 100 \\ \text { Male } & 9 / 5 & 2 / 1 & 18 / 10 & 160 / 84 & 189 / 100 \\ \text { TOTAL } & 9 / 4 & 4 / 2 & 21 / 9 & 211 / 86 & 245 / 100 \\ \text { Chi-square }(3, \underline{N}=245) & =5.42, p=.14 . & \text { No response: } 6 .\end{array}$

Gender by Human Resource Management

$\begin{array}{llrrrr} & 1 \text { (low) } & 2 & \underline{3} & \underline{4} \text { (high) } & \text { Total } \\ \text { Female } & 0 / 0 & 4 / 7 & 8 / 14 & 44 / 79 & 56 / 100 \\ \text { Male } & 5 / 3 & 12 / 6 & 59 / 31 & 113 / 60 & 189 / 100 \\ \text { TOTAL } & 5 / 2 & 16 / 7 & 67 / 27 & 157 / 64 & 245 / 100\end{array}$

Chi-square $(3, \underline{N}=245)=8.43, p=.04$. No response: 6 .

Gender by Facility and Property Management

1 (low) $2 \quad \underline{3} \quad \underline{4}$ (high) Total

$\begin{array}{lrrrrr}\text { Female } & 0 / 0 & 1 / 2 & 22 / 39 & 33 / 59 & 56 / 100 \\ \text { Male } & 5 / 3 & 7 / 4 & 70 / 37 & 107 / 57 & 89 / 100\end{array}$

$\begin{array}{llllll}\text { TOTAL } & 5 / 2 & 8 / 3 & 92 / 38 & 140 / 57 & 245 / 100\end{array}$

Chi-square $(3, \underline{N}=245)=2.07, p=.56$. No response: 6 . 
TABLE XLI

INQUIRY QUESTION 4 RESULTS

(continued)

(Frequencies/Percent)

Gender by Information Management

1 (low) $2 \quad 3 \quad 4$ (high) Total

$\begin{array}{llllll}\text { Female } & 0 / 0 & 2 / 4 & 18 / 32 & 36 / 64 & 56 / 100\end{array}$

$\begin{array}{llllll}\text { Male } & 7 / 4 & 9 / 5 & 68 / 36 & 106 / 56 & 190 / 100\end{array}$

$\begin{array}{llllll}\text { TOTAL } & 7 / 3 & 11 / 5 & 86 / 35 & 142 / 58 & 246 / 100\end{array}$

Chi-square $(3, \underline{N}=246)=2.90, p=.41$. No response: 5 .

Gender by Management of Ancillary Services

$\begin{array}{lcrrrr} & \underline{1(\mathrm{low})} & \underline{2} & \underline{3} & \underline{4 \text { (high) }} & \underline{\text { Total }} \\ \text { Female } & 0 / 0 & 3 / 6 & 25 / 47 & 25 / 47 & 53 / 100 \\ \text { Male } & 7 / 4 & 14 / 8 & 96 / 52 & 69 / 37 & 186 / 100 \\ \text { TOTAL } & 7 / 3 & 17 / 7 & 121 / 51 & 94 / 39 & 239 / 100 \\ \text { Chi-square }(3, \underline{N}=239) & =3.42, p=.33 . & \text { No response: } 12 .\end{array}$

The results for Inquiry Question 6 are shown in Table XLIII. There appears to be no significant difference in the perception of the importance of the areas of training relating to the respondents' district types.

The importance values assigned to the areas of training are the same as for the previous tables. 
TABLE XLII

INQUIRY QUESTION 5 RESULTS

(Frequencies/Percent)

Lecation by Educational Enterprise

1 (low) 2 3 3 (high) Total

$\begin{array}{llllll}\text { Canada } & 0 / 0 & 1 / 7 & 4 / 27 & 10 / 67 & 15 / 100\end{array}$

$\begin{array}{llllll}\text { U.S. East } & 2 / 4 & 7 / 16 & 15 / 33 & 21 / 47 & 45100\end{array}$

$\begin{array}{llllll}\text { U.S. South } & 1 / 3 & 3 / 9 & 9 / 26 & 21 / 62 & 34 / 100\end{array}$

U.S. Midwest $3 / 4 \quad 6 / 7 \quad 31 / 36 \quad 45 / 53 \quad 85 / 100$

$\begin{array}{llllll}\text { U.S. West } & 2 / 3 & 1 / 2 & 30 / 48 & 30 / 48 & 63 / 100\end{array}$

$\begin{array}{llllll}\text { TOTAL } & 8 / 3 & 18 / 7 & 89 / 37 & 127 / 52 & 242 / 100\end{array}$

Chi-square $(12, \underline{N}=242)=12.98, p=.37$. No response: 9 .

Location by Financial Resource management

1 (low) $2 \quad 3 \quad 4$ (high) Total

$\begin{array}{llllll}\text { Canada } & 0 / 0 & 0 / 0 & 2 / 13 & 14 / 88 & 16 / 100\end{array}$

$\begin{array}{llllll}\text { U.S. East } & 3 / 6 & 1 / 2 & 4 / 9 & 39 / 83 & 47 / 100\end{array}$

$\begin{array}{llllll}\text { U.S. South } & 0 / 0 & 1 / 3 & 1 / 3 & 32 / 94 & 34 / 100\end{array}$

$\begin{array}{llllll}\text { U.S. Midwest } & 4 / 5 & 0 / 0 & 6 / 7 & 76 / 88 & 86 / 100\end{array}$

$\begin{array}{llllll}\text { U.S. West } & 2 / 3 & 2 / 3 & 8 / 13 & 51 / 81 & 63 / 100\end{array}$

$\begin{array}{llllll}\text { TOTAL } & 9 / 4 & 4 / 2 & 21 / 9 & 212 / 86 & 246 / 100\end{array}$

Chi-square $(12, \underline{N}=246)=9.70, p=.64$. No response: 5 . 
TABLE XLII

INQUIRY QUESTION 5 RESULTS

(continued)

(Frequencies/Percent)

Location by Human Resource Management

$\begin{array}{lclrrl} & \underline{1} \text { (low) } & \underline{2} & \underline{3} & \underline{4 \text { (high) }} & \text { Total } \\ \text { Canada } & 0 / 0 & 1 / 6 & 4 / 25 & 11 / 69 & 16 / 100 \\ \text { U.S. East } & 1 / 2 & 5 / 11 & 15 / 32 & 26 / 55 & 47 / 100 \\ \text { U.S. South } & 0 / 0 & 2 / 6 & 7 / 21 & 25 / 74 & 34 / 100 \\ \text { U.S. Midwest } & 3 / 3 & 2 / 2 & 23 / 26 & 59 / 68 & 87 / 100 \\ \text { U.S. West } & 1 / 2 & 6 / 10 & 18 / 29 & 37 / 60 & 62 / 100 \\ \text { TOTAL } & 5 / 2 & 16 / 7 & 67 / 27 & 158 / 64 & 246 / 100 \\ \text { Chi-square }(12, \underline{N}=246) & =9.03, p=.70 . & \text { No response: } 5 .\end{array}$

Location by Facility and Property Management

$\begin{array}{lccrcc} & 1 \text { (low) } & 2 & \underline{3} & \underline{4 \text { (high) }} & \text { Total } \\ \text { Canada } & 0 / 0 & 1 / 6 & 3 / 19 & 12 / 75 & 16 / 100 \\ \text { U.S. East } & 2 / 4 & 1 / 2 & 20 / 43 & 23 / 50 & 46 / 100 \\ \text { U.S. South } & 0 / 0 & 0 / 0 & 13 / 38 & 21 / 62 & 34 / 100 \\ \text { U.S. Midwest } & 2 / 2 & 4 / 5 & 25 / 29 & 56 / 64 & 87 / 100 \\ \text { U.S. West } & 1 / 2 & 2 / 3 & 31 / 49 & 29 / 46 & 63 / 100 \\ \text { TOTAL } & 5 / 2 & 8 / 3 & 92 / 37 & 141 / 57 & 246 / 100 \\ \text { Chi-square }(12, \underline{\mathrm{N}}=246) & =14.14, \mathrm{p}=.29 \text {. No response: } 5 .\end{array}$


TABLE XLII

INQUIRY QUESTION 5 RESULTS

(continued)

(Frequencies/Percent)

Location by Information Management

$\begin{array}{lrrrrr} & \text { 1(low) } & 2 & \underline{3} & \underline{4} \text { (high) } & \text { Total } \\ \text { Canada } & 0 / 0 & 1 / 6 & 8 / 50 & 7 / 44 & 16 / 100 \\ \text { U.S. East } & 2 / 4 & 1 / 2 & 22 / 47 & 22 / 48 & 47 / 100 \\ \text { U.S. South } & 0 / 0 & 2 / 6 & 8 / 24 & 24 / 71 & 34 / 100 \\ \text { U.S. Midwest } & 3 / 3 & 4 / 5 & 21 / 24 & 59 / 68 & 87 / 100 \\ \text { U.S. West } & 2 / 3 & 3 / 5 & 27 / 43 & 31 / 49 & 63 / 100 \\ \text { TOTAL } & 7 / 3 & 11 / 4 & 86 / 35 & 143 / 58 & 247 / 100\end{array}$

Chi-square $(12, \underline{N}=247)=15.82, p=.20$. No response: 4 .

Location by Management of Ancillary Services

\begin{tabular}{|c|c|c|c|c|c|}
\hline & 1 (low) & $\underline{2}$ & 3 & 4 (high) & Total \\
\hline Canada & $0 / 0$ & $1 / 7$ & $8 / 53$ & $6 / 40$ & $15 / 100$ \\
\hline U.S. East & $2 / 4$ & $3 / 6$ & $25 / 53$ & $17 / 36$ & $47 / 100$ \\
\hline U.S. South & $0 / 0$ & $1 / 3$ & $16 / 48$ & $16 / 48$ & $33 / 100$ \\
\hline U.S. Midwest & $3 / 4$ & $7 / 8$ & $42 / 51$ & $31 / 37$ & $83 / 100$ \\
\hline U.S. West & $2 / 3$ & $5 / 8$ & $30 / 48$ & $25 / 40$ & $62 / 100$ \\
\hline TOTAL & $7 / 3$ & $17 / 7$ & $121 / 50$ & $95 / 40$ & $240 / 100$ \\
\hline
\end{tabular}


TABLE XLIII

INQUIRY QUESTION 6 RESULTS

(Frequencies/Percent)

District Type by Educational Enterprise

$\begin{array}{lccccc} & 1 \text { (low) } & 2 & 3 & \underline{4 \text { (high) }} & \text { Total } \\ \text { Urban } & 1 / 2 & 3 / 6 & 17 / 36 & 26 / 55 & 47 / 100 \\ \text { Suburban } & 3 / 4 & 4 / 5 & 32 / 41 & 39 / 50 & 78 / 100 \\ \text { Rural } & 4 / 4 & 9 / 10 & 39 / 42 & 40 / 43 & 92 / 100 \\ \text { TOTAL } & 8 / 4 & 16 / 7 & 88 / 41 & 105 / 48 & 217 / 100 \\ & & & & & \\ \text { Chi-square }(6, \underline{N}=217) & =3.02, p=.81 . & \text { No response: } 34 .\end{array}$

District Type by Financial Resource Management

1 (low) $2 \quad 3 \quad 4$ (high) Iotal

$\begin{array}{llllll}\text { Urban } & 2 / 4 & 0 / 0 & 2 / 4 & 44 / 92 & 48 / 100\end{array}$

$\begin{array}{llllll}\text { Suburban } & 4 / 5 & 2 / 2 & 8 / 10 & 67 / 83 & 81 / 100\end{array}$

$\begin{array}{llllll}\text { Rural } & 3 / 3 & 2 / 2 & 7 / 8 & 80 / 87 & 92 / 100\end{array}$

$\begin{array}{llllll}\text { TOTAL } & 9 / 4 & 4 / 2 & 17 / 8 & 191 / 86 & 221 / 100\end{array}$

Chi-square $(6, \underline{N}=221)=2.99, p=.81$. No response: 30 .

District Type by Human Resource Management

1 (low) $2 \quad 3 \quad 4$ (high) Total

$\begin{array}{lrrrrr}\text { Urban } & 0 / 0 & 3 / 6 & 11 / 23 & 34 / 71 & 48 / 100 \\ \text { Suburban } & 2 / 2 & 7 / 9 & 23 / 28 & 49 / 60 & 81 / 100 \\ \text { Rural } & 3 / 3 & 5 / 5 & 30 / 33 & 54 / 59 & 92 / 100 \\ \text { TOTAL } & 5 / 2 & 15 / 7 & 64 / 29 & 137 / 62 & 221 / 100\end{array}$

Chi-square $(6, \underline{N}=221)=4.02, p=.67$. No response: 30 . 
TABLE XLIII
INQUIRY QUESTION 6 RESULTS
(continued)

(Frequencies/Percent)

District Type by Facility and Property Management

$\begin{array}{lccccc} & 1 \text { (low) } & 2 & \underline{3} & \underline{4} \text { (high) } & \text { Total } \\ \text { Urban } & 1 / 2 & 1 / 2 & 15 / 31 & 31 / 65 & 48 / 100 \\ \text { Suburban } & 3 / 4 & 2 / 2 & 30 / 37 & 46 / 57 & 81 / 100 \\ \text { Rural } & 1 / 1 & 5 / 5 & 39 / 42 & 48 / 52 & 93 / 100 \\ \text { TOTAL } & 5 / 2 & 8 / 4 & 84 / 38 & 125 / 56 & 222 / 100\end{array}$

Chi-square $(6, \underline{N}=222)=4,67, p=.59$. No response: 29 .

District Type by Information Management

$\begin{array}{lccccc} & \underline{1 \text { (low) }} & \underline{2} & \underline{3} & \underline{4 \text { (high) }} & \text { Total } \\ \text { Urban } & 1 / 2 & 2 / 4 & 17 / 35 & 28 / 58 & 48 / 100 \\ \text { Suburban } & 4 / 5 & 2 / 2 & 24 / 30 & 51 / 63 & 81 / 100 \\ \text { Rural } & 2 / 2 & 6 / 6 & 36 / 39 & 49 / 53 & 93 / 100 \\ \text { TOTAL } & 7 / 3 & 10 / 5 & 77 / 35 & 128 / 58 & 222 / 100 \\ \text { Chi-square }(6, \underline{N}=222) & =4.67, \mathrm{p}=.59 . & \text { No response: } 29 .\end{array}$

District Type by Management of Ancillary Services

$\begin{array}{lccccc} & \underline{1(\text { low) }} & \underline{2} & \underline{3} & \underline{4 \text { (high) }} & \text { Total } \\ \text { Urban } & 0 / 0 & 4 / 9 & 24 / 52 & 18 / 39 & 46 / 100 \\ \text { Suburban } & 4 / 5 & 5 / 6 & 37 / 47 & 33 / 42 & 79 / 100 \\ \text { Rural } & 3 / 3 & 8 / 9 & 50 / 55 & 30 / 33 & 91 / 100 \\ \text { TOTAL } & 7 / 3 & 17 / 8 & 111 / 51 & 81 / 38 & 216 / 100 \\ \text { Chi-square }(6, \underline{\mathrm{N}}=216) & =4.14, \mathrm{p}=.66 . & \text { No response: } 35 .\end{array}$


The results for Inquiry Question 7 are shown in Table XLIV. There appears to be no significant difference in the perception of the importance of the areas of training relating to the respondents' education. A trend is indicated in the perception of the importance of Human Resource Management. Again, the importance values remain the same.

TABLE XLIV

INQUIRY QUESTION 7 RESULTS

(Frequencies/Percent)

Education by Educational Enterprise

\begin{tabular}{llrrrr} 
& 1 (low) & 2 & \multicolumn{1}{c}{3} & 4(high) & \multicolumn{1}{c}{ Total } \\
High school/College & $2 / 10$ & $0 / 0$ & $9 / 43$ & $10 / 48$ & $21 / 100$ \\
Bachelors Degree & $0 / 0$ & $4 / 7$ & $28 / 48$ & $26 / 45$ & $58 / 100$ \\
Graduate Degree & $6 / 4$ & $13 / 9$ & $51 / 36$ & $72 / 51$ & $142 / 100$ \\
TOTAL & $8 / 4$ & $17 / 8$ & $88 / 40$ & $108 / 49$ & $221 / 100$
\end{tabular}

Chi-square $(6, \underline{N}=221)=8.26, p=.22$. No response: 30 .

Education by Financial Resource Management

1 (low) $2 \underline{3} \quad \underline{4 \text { (high) }} \quad \underline{\text { Total }}$

$\begin{array}{llllll}\text { High school/College } & 2 / 9 & 1 / 5 & 1 / 5 & 18 / 82 & 22 / 100\end{array}$

$\begin{array}{llllll}\text { Bachelors Degree } & 0 / 0 & 2 / 3 & 7 / 11 & 54 / 86 & 63 / 100\end{array}$

$\begin{array}{llllll}\text { Graduate Degree } & 7 / 5 & 1 / 1 & 10 / 7 & 122 / 87 & 140 / 100\end{array}$

$\begin{array}{llllll}\text { TOTAL } & 9 / 4 & 4 / 2 & 18 / 8 & 194 / 86 & 225 / 100\end{array}$

Chi-square $(6, \underline{N}=225)=8.11, p=.23$. No response: 26 . 
TABLE XLIV

INQIJIRY QUESTION 7 RESULTS

(continued)

(Frequencies/Percent)

Education by Human Resource Management

1 (low) $2 \quad 3 \quad \underline{3}$ (high) Total

$\begin{array}{llllll}\text { High school/College } \quad 0 / 0 & 3 / 14 & 4 / 18 & 15 / 68 & 22 / 100\end{array}$

$\begin{array}{lllll}\text { Bachelors Degree } \quad 0 / 0 & 7 / 11 & 13 / 21 & 42 / 68 & 62 / 100\end{array}$

$\begin{array}{llllll}\text { Graduate Degree } & 5 / 4 & 6 / 4 & 47 / 33 & 83 / 59 & 141 / 100\end{array}$

$\begin{array}{llllll}\text { TOTAL } & 5 / 2 & 16 / 7 & 64 / 28 & 140 / 62 & 225 / 100\end{array}$

Chi-square $(6, \underline{N}=225)=11.34, p=.08$. No response: 26 .

Education by Facility and Property Management

$\begin{array}{lcccrc} & 1 \text { (low) } & \underline{2} & \underline{3} & \underline{4} \text { (high) } & \text { Total } \\ \text { High school/College } & 1 / 5 & 1 / 5 & 11 / 50 & 9 / 41 & 22 / 100 \\ \text { Bachelors Degree } & 0 / 0 & 2 / 3 & 24 / 38 & 37 / 59 & 63 / 100 \\ \text { Graduate Degree } & 4 / 3 & 5 / 4 & 51 / 36 & 81 / 57 & 141 / 100 \\ \text { TOTAL } & 5 / 2 & 8 / 4 & 86 / 38 & 127 / 56 & 226 / 100\end{array}$

Chi-square $(6, \underline{N}=226)=4.25, p=.64$. No response: 25 .

Education by Information Management

1 (low) $2 \quad 3 \quad 4$ (high) Total

$\begin{array}{llllll}\text { High school/College } & 1 / 5 & 2 / 9 & 6 / 27 & 13 / 59 & 22 / 100\end{array}$

$\begin{array}{llllll}\text { Bachelors Degree } & 0 / 0 & 3 / 5 & 25 / 40 & 35 / 56 & 63 / 100\end{array}$

$\begin{array}{llllll}\text { Graduate Degree } \quad 6 / 4 & 6 / 4 & 46 / 33 & 83 / 59 & 141 / 100\end{array}$

$\begin{array}{llllll}\text { TOTAL } & 7 / 3 & 11 / 5 & 77 / 34 & 131 / 58 & 226 / 100\end{array}$

Chi-square $(6, \underline{N}=226)=4.68, p=.59$. No response: 25 . 
TABLE XLIV

INQUIRY QUESTION 7 RESULTS

(continued)

(Frequencies/Percent)

Education by Management of Ancillary Services

1 (low) $2 \quad 3 \quad 4$ (high) Total

$\begin{array}{llllll}\text { High school/College } \quad 0 / 0 & 3 / 14 & 11 / 52 & 7 / 33 & 21 / 100\end{array}$

$\begin{array}{llllll}\text { Bachelors Degree } & 2 / 3 & 4 / 7 & 32 / 52 & 23 / 38 & 61 / 100\end{array}$

$\begin{array}{llllll}\text { Graduate Degree } & 5 / 4 & 10 / 7 & 70 / 51 & 53 / 38 & 138 / 100\end{array}$

$\begin{array}{llllll}\text { TOTAL } & 7 / 3 & 17 / 8 & 113 / 51 & 83 / 38 & 220 / 100\end{array}$

Chi-square $(6, \underline{N}=221)=2.23, p=.90$. No response: 31 .

The results for Inquiry Question 8 are shown in Table XLV. There appears to be no significant difference in the perception of the importance of the areas of training relating to the respondents' university types. The importance values assigned to the areas of training continue to be:

1-Unimportant (low); 2-Somewhat unimportant; 3-Somewhat important; 4-Important (high). 
TABLE XLV

INQUIRY QUESTION 8 RESULTS

(Frequencies/Percent)

University Type by Educational Enterprise

1 (low) $2 \quad 3 \quad 4$ (high) Total

Research

Comprehensive

Doctoral

$0 / 0 \quad 0 / 0 \quad 0 / 0 \quad 4 / 100 \quad 4 / 100$

$\begin{array}{lllll}4-Y e a r & P l u s \\ & 0 / 0 & 2 / 11 & 3 / 16 & 14 / 74\end{array}$

$\begin{array}{llllll}\text { TOTAL } & 1 / 3 & 3 / 8 & 4 / 11 & 28 / 78 & 36 / 100\end{array}$

Chi-square $(6, \underline{N}=36)=4.43, p=.88$. Results are suspect.

University Type by Financial Resource Management

1 (low) 3 4(high) Total

Research

$0 / 0 \quad 0 / 0 \quad 4 / 100 \quad 4 / 100$

$\begin{array}{lllll}\text { Comprehensive } & 1 / 9 & 1 / 9 & 9 / 82 & 11 / 100\end{array}$

$\begin{array}{lllll}\text { Doctoral } & 0 / 0 & 0 / 0 & 2 / 100 & 2 / 100\end{array}$

4-Year Plus Graduate $\quad 1 / 5 \quad 0 / 0 \quad 18 / 95 \quad 19 / 100$

$\begin{array}{lllll}\text { TOTAL } & 2 / 6 & 1 / 3 & 33 / 92 & 36 / 100\end{array}$

Chi-square $(6, \underline{N}=36)=3.04, p=.80$. Results are suspect.

University Type by Human Resource Management

$$
1 \text { (low) } 2 \quad 3 \quad 4 \text { (high) Total }
$$

Research

Comprehensive

$0 / 0 \quad 0 / 0 \quad 0 / 0 \quad 4 / 100 \quad 4 / 100$

Doctoral

$1 / 9 \quad 0 / 0 \quad 2 / 18 \quad 8 / 73 \quad 11 / 100$

4-Year Plus Graduate

$0 / 0 \quad 0 / 0 \quad 1 / 50$

$1 / 50 \quad 2 / 100$

$\begin{array}{lllll}0 / 0 & 2 / 11 & 4 / 21 & 13 / 68 & 19 / 100\end{array}$

TOTAL

$\begin{array}{lllll}1 / 3 & 2 / 6 & 7 / 19 & 26 / 72 & 36 / 100\end{array}$

Chi-square $(9, \underline{N}=36)=6.44, p=.70$. Results are suspect. 
TABLE XLV

INQUIRY QUESTION 8 RESULTS

(continued)

(Frequencies/Percent)

University Type by Facility and Property Management

\begin{tabular}{lccccr} 
& 1 (low) & $\underline{2}$ & $\underline{3}$ & $\underline{4 \text { (high) }}$ & \multicolumn{1}{c}{ Total } \\
Research & $0 / 0$ & $0 / 0$ & $1 / 25$ & $3 / 75$ & $4 / 100$ \\
Comprehensive & $1 / 9$ & $0 / 0$ & $3 / 27$ & $7 / 64$ & $11 / 100$ \\
Doctoral & $0 / 0$ & $0 / 0$ & $1 / 50$ & $1 / 50$ & $2 / 100$ \\
4-Year Plus Graduate & $1 / 5$ & $1 / 5$ & $5 / 26$ & $12 / 63$ & $19 / 100$ \\
& & & & & \\
TOTAL & $2 / 6$ & $1 / 3$ & $10 / 28$ & $23 / 64$ & $36 / 100$
\end{tabular}

Chi-square $(9, \underline{N}=36)=2.00, p=.99$. Results are suspect.

University Type by Information Management

$\begin{array}{llllr}1 \text { (low) } & 2 & \underline{3} & \underline{4} \text { (high) } & \text { Total } \\ 0 / 0 & 0 / 0 & 2 / 50 & 2 / 50 & 4 / 100 \\ 1 / 9 & 0 / 0 & 3 / 27 & 7 / 64 & 11 / 100 \\ 0 / 0 & 0 / 0 & 0 / 0 & 2 / 100 & 2 / 100 \\ 1 / 5 & 1 / 5 & 4 / 21 & 13 / 68 & 19 / 100 \\ & & & & \\ 2 / 6 & 1 / 3 & 9 / 25 & 24 / 67 & 36 / 100\end{array}$

Chi-square $(9, \underline{N}=36)=3.64, p=.93$. Results are suspect. 
TABLE XLV

INQUIRY QUESTION 8 RESULTS

(continued)

(Frequencies/Percent)

University Type by Management of Ancillary Services

$\begin{array}{lllllr} & 1 \text { (low) } & \underline{2} & \underline{3} & \underline{4 \text { (high) }} & \text { Total } \\ \text { Research } & 0 / 0 & 0 / 0 & 2 / 50 & 2 / 50 & 4 / 100 \\ \text { Comprehensive } & 1 / 10 & 0 / 0 & 5 / 50 & 4 / 40 & 10 / 100 \\ \text { Doctoral } & 0 / 0 & 0 / 0 & 1 / 50 & 1 / 50 & 2 / 100 \\ \text { 4-Year Plus Graduate } & 0 / 0 & 2 / 11 & 7 / 37 & 10 / 53 & 19 / 100 \\ \text { TOTAL } & 1 / 3 & 2 / 6 & 15 / 43 & 17 / 49 & 35 / 100\end{array}$

Chi-square $(9, \underline{N}=35)=4.75, p=.86$. Results are suspect.

Inquiry Question 9 sought any difference between the respondents' perceptions of the importance of Foundations of Teaching and Learning as related to the importance of staff development. Table XLVI displays the statistical comparisons. The importance values assigned to the areas of training remain the same.

There appears to be a significant difference in the respondents' perceptions of the importance of Foundations of Teaching and Learning as related to the importance of staff development. 
TABLE XLVI

INQUIRY QUESTION 9 RESULTS

(Frequencies/Percent)

Importance of Foundations of Teaching and Learning by Importance of Staff Development

Staff Development

\begin{tabular}{llllll} 
Teaching \& Learning & 1 (low) & 2 & 3 & $\underline{4}$ high) & Total \\
\cline { 2 - 5 } & & & & & \\
1 (low) & $3 / 21$ & $4 / 29$ & $7 / 50$ & $0 / 0$ & $14 / 100$ \\
2 & $2 / 3$ & $12 / 20$ & $36 / 60$ & $10 / 17$ & $60 / 100$ \\
3 & $2 / 2$ & $5 / 6$ & $46 / 55$ & $31 / 37$ & $84 / 100$ \\
4 (high) & $1 / 1$ & $1 / 1$ & $23 / 32$ & $46 / 65$ & $71 / 100$ \\
& 1 & 2 & 3 & 4 & Total \\
TOTAL & $8 / 3$ & $22 / 10$ & $112 / 49$ & $87 / 38$ & $229 / 100$ \\
Chi-square $(9, \underline{N}=229)$ & $=64.2, p=.00$. No response: 22.
\end{tabular}

Inquiry Questions 10 and 11 relate to the rank preference of different areas of training by source and by importance. These are summarized in Tables XLVII and XLVIII respectively. The various sources are ranked in general and by major area, and then by specific area where at least 100 respondents preferred one source.

In Table XLVIII the importance values are ranked according to frequency of the Important rating. The number of Somewhat Important responses is also noted, and the total importance percentage combines both responses.

As with the research questions, conclusions and observations derived from the inquiry questions are summarized in Chapter V. 
TABLE XLVII

RANK ORDER PREFERENCE OF SOURCE FOR

PROFESSIONAL TRAINING OF SCHOOL BUSINESS OFFICIALS

Number Percent

A. In General

No response

$108 \quad 43.0$

College Preparation

$60 \quad 23.9$

Continuing Education/Workshop

$51 \quad 20.3$

On-The-Job Experience

$32 \quad 12.7$

B. By Major Subject Area

College

Educational Enterprise

$149 \quad 59.4$

Financial Resource

Information

$146 \quad 58.2$

$111 \quad 44.2$

Human Resource

$108 \quad 43.0$

Facility and Property

$63 \quad 25.1$

Ancillary Services

$\begin{array}{ll}42 & 16.7\end{array}$

Workshop

Facility and Property

Ancillary Services

Human Resource

Information

Financial Resource

Educational Enterprise

$103 \quad 41.0$

$91 \quad 36.3$

$84 \quad 33.5$

$78 \quad 31.1$

$\begin{array}{ll}62 & 24.7\end{array}$

$43 \quad 17.1$

Experience

Ancillary Services

$89 \quad 35.5$

Facility and Property

$64 \quad 25.5$

Educational Enterprise

$47 \quad 18.7$

Human Resource

$45 \quad 17.9$

Information

$35 \quad 13.9$

Financial Resource

$32 \quad 12.7$ 
TABLE XLVII

RANK ORDER PREFERENCE OF SOURCE FOR PROFESSIONAL TRAINING OF SCHOOL BUSINESS OFFICIALS (continued)

Number Percent

Network

Information

Ancillary Services

Facility and Property

Human Resource

Financial Resource

Educational Enterprise

Independent Study

Information

Ancillary Services

Educational Enterprise

Facility and Property

Human Resource

Financial Resource

$\begin{array}{ll}17 & 6.8\end{array}$

$16 \quad 6.4$

$13 \quad 5.2$

$9 \quad 3.6$

$6 \quad 2.4$

$2 \quad .8$

$5 \quad 2.0$

$4 \quad 1.6$

$3 \quad 1.2$

$2 \quad .8$

$1 \quad .4$

$0 \quad 0$

C. By Specific Area--Where at least 100

Respondents (40\%) Preferred One Source

College

Accounting, Auditing, and Financial

Reporting

Principles of School Finance

$\begin{array}{ll}178 & 70.9\end{array}$

Foundations of Teaching and Learning

Organization and Administration

$177 \quad 70.5$

$168 \quad 66.9$

Budgeting and Financial Planning

$166 \quad 66.1$

Cash Management, Investment and Debt

$139 \quad 55.4$

Legal Aspects

$112 \quad 44.6$

$111 \quad 44.2$ 
TABLE XLVII

RANK ORDER PREFERENCE OF SOURCE FOR

PROFESSIONAL TRAINING OF SCHOOL BUSINESS OFFICIALS (continued)

\section{Number Percent}

$\begin{array}{lll}\text { Workshop } & & \\ \text { Risk Management } & 161 & 64.1 \\ \text { Staff Development } & 142 & 56.6 \\ \text { Health and Safety } & 129 & 51.4 \\ \text { Personnel and Benefits Administration } & 124 & 49.4 \\ \text { Transportation } & 121 & 48.2 \\ \text { Food Service } & 121 & 48.2 \\ \text { Strategic Planning } & 120 & 47.8 \\ \text { Supplies and Equipment } & 114 & 45.4 \\ \text { Cash Management, Investment and Debt } & 112 & 44.6 \\ \text { Purchasing } & 105 & 41.8 \\ \text { Labor Relations, Collective Bargaining } & 104 & 41.4 \\ \text { Management-Information Systems } & 101 & 40.2 \\ \text { Real-Estate Management } & 100 & 39.8 \\ \text { Legal Aspects } & 100 & 39.8\end{array}$

TABLE XLVIII

RANK ORDER OF IMPORTANCE FOR AREA OF PROFESSIONAL TRAINING OF SCHOOL BUSINESS OFFICIALS

Number

Somewhat Combined Important Important Percent

By Major Subject Area

Financial Resource Management

Human Resource

Management

Information Management

Facility and Property

Management

Educational Enterprise

Management of Ancillary Services

212

158

143

141

127

95
21

67

86

92

89

121
92.9

89.6

91.3

92.9

86.1

86.0 
TABLE XLVIII

RANK ORDER OF IMPORTANCE FOR AREA OF

PROFESSIONAL TRAINING OF SCHOOL BUSINESS OFFICIALS

(continued)

\begin{tabular}{|c|c|c|c|}
\hline & \multicolumn{2}{|c|}{ Number } & \multirow[b]{2}{*}{$\begin{array}{l}\text { Combine } \\
\text { Percen }\end{array}$} \\
\hline & Important & $\begin{array}{l}\text { Somewhat } \\
\text { Important }\end{array}$ & \\
\hline \multicolumn{4}{|l|}{$\begin{array}{l}\text { By Specific Area--Where at least } \\
100 \text { Respondents (40\%) } \\
\text { Identified an Area as Important } \\
\text { Budaeting and Financial }\end{array}$} \\
\hline $\begin{array}{l}\text { Planning } \\
\text { Accounting, Auditing, and }\end{array}$ & 228 & 10 & 94.8 \\
\hline Financial Reporting & 204 & 32 & 94.0 \\
\hline Principles of School Finance & 199 & 36 & 93.6 \\
\hline $\begin{array}{l}\text { Legal Aspects } \\
\text { Cash Management Investment }\end{array}$ & 184 & 50 & 93.2 \\
\hline and Debt & 178 & 52 & 91.6 \\
\hline Organization and Administration & 150 & 76 & 90.1 \\
\hline $\begin{array}{l}\text { Communications } \\
\text { Labor Relations/Collective }\end{array}$ & 148 & 81 & 91.3 \\
\hline Bargaining & 147 & 71 & 86.9 \\
\hline Human Relations & 146 & 79 & 89.7 \\
\hline Personnel and Benefits & & & \\
\hline Administration & 145 & 88 & 92.9 \\
\hline Management Information & & & \\
\hline Systems & 140 & 83 & $\begin{array}{l}88.9 \\
87.7\end{array}$ \\
\hline $\begin{array}{l}\text { Risk Management } \\
\text { Purchasing }\end{array}$ & $\begin{array}{l}139 \\
137\end{array}$ & $\begin{array}{l}81 \\
94\end{array}$ & $\begin{array}{l}87.7 \\
92.1\end{array}$ \\
\hline Strategic Planning & 135 & 73 & 82.9 \\
\hline Public Policy and & & & \\
\hline Intergovernmental Relations & 131 & 88 & 87.3 \\
\hline Maintenance and Operations & 129 & 94 & 88.9 \\
\hline Planning and Construction & 117 & 101 & 86.8 \\
\hline Health and Safety & 110 & 104 & 85.2 \\
\hline
\end{tabular}




\section{CHAPTER $V$}

\section{CONCLUSIONS AND RECOMMENDATIONS}

The conclusions of the survey are presented in three sections. First, answers to the research questions will be addressed. Next, comments related to the inquiry questions are offered. Finally, general conclusions based on the comments resulting from the open-ended questions will be considered.

A critique of the research process will follow the inquiry-question conclusions. To close the research study, recommendations and observations are offered for the key groups affected--those are school business officials, superintendents, universities, and school business associations.

\section{RESEARCH QUESTIONS}

A summary of the statistical analysis (Table XLIX) shows that there are no significant differences in any of the six research questions.

Further explanation is needed to clarify the three trends indicated. Table $\mathrm{XI}$, analyzing the Research Question 2 variables, shows a trend toward a difference in how training sources for facility and property management are preferred by various responsibility groups. Superintendents prefer college to workshops in this area by 47 percent to 38 percent. Business administrators, however, prefer workshops to college for the same training, at a 45 percent to 
20 percent rate. Overall, all respondents indicated a 25 percent preference for college and a 41 percent preference for workshops.

TABLE XLIX

SUMMARY OF ANALYSIS

Research Significant

Question No. Difference? Trend? Area?

$\begin{array}{cccc}1 & \text { No } & \text { No } & \ldots \\ 2 & \text { No } & \text { Yes } & \text { Facility and Property Management } \\ 3 & \text { No } & \text { Yes } & \text { Financial Resource Management } \\ 4 & \text { No } & \text { No } & \ldots \\ 5 & \text { No } & \text { No } & -.- \\ 6 & \text { No } & \text { Yes } & \text { Human Resource Management }\end{array}$

One reason for such a difference may be based on the practitioners' (SBOs') perceptions of what has helped in the past versus the educators' (superintendents') preferred source of training. A factor for the SBOs' view could be the limited availability of college course work in this area. A practical application of this trend for school business job candidates is for them to take some college training in this area to enhance the superintendents' perceptions of the candidates' qualifications.

Research Question 3 indicates a likely difference in the university respondents' preferences for sources of training in Financial Resource Management. Table XV shows that comprehensive university respondents all felt a college source is appropriate. For research and doctoral university respondents, only one-third felt college was most appropriate. Of the total 
group, 74 percent preferred college classes for this area of training.

When evaluating the overall perceptions of different job responsibilities (Table IX), all of those groups--school business administrators, specialists, and superintendents, preferred college as the source, in a range of 57 to 59 percent.

There does not appear to be a difference in the preferred source for Financial Resource Management. In fact, this area received the second highest ranking overall (58 percent) for college as a preferred source (Table XLVII). However, the trend should be interpreted with caution, as it may merely reflect the small number of respondents (3) in the research and doctoral categories and the small number of university respondents. An additional limitation here is that the university-respondent categories overlap.

Table XXXIV shows the third trend, a different importance value for Human Resource Management, based on job responsibilities. Of the specialist group, 78 percent ranked Human Resource Management as Important, while 58 percent of both superintendents and business administrators selected the area as Important. Overall, 91 percent felt this area was Important or Somewhat Important, indicating agreement on value but not on the degree of value.

Perhaps superintendents and business administrators tended to balance the value of areas because of the broader scope of their positions, while the specialists have more limited scope. In fact, Tables XXXII through XXXVII show that the specialists give a higher importance to all areas and Human Resource Management is just the area with a larger degree of difference. 
Another reason may be the nature of bureaucracy. Those in positions less able to influence events, such as the specialists, may have to rely more upon human relations to get things done and, hence, place higher value on this area.

The conclusions to the six research questions are as follows:

1. There is no significant difference regarding the generally preferred source of training, that relates to the respondents' five geographic locations.

2. There is no significant difference regarding the preferred source of training for the six general areas, that relates to the respondents' job responsibilities.

3. There is no significant difference regarding the preferred source of training in the six general areas, that relates to the university respondents' university types.

4. There is no significant difference regarding the importance of the six general areas, that relates to the annual budgets of respondents' districts.

5. There is no significant difference regarding the importance of the six general areas, that relates to respondents' school business experience.

6. There is no significant difference regarding the importance of the six general areas, that relates to respondents' job responsibilities. 
INQUIRY QUESTIONS

Table $L$ summarizes the statistical analysis of the eleven inquiry questions.

\section{TABLE L}

REVIEW OF INQUIRY QUESTIONS

Statistical Analysis Summary

Inquiry

Question Significant

Number Difference?

\begin{tabular}{|c|c|c|}
\hline Area? & Trend? & Area? \\
\hline --- & Yes & Supply and Equipment \\
\hline -- & No & --- \\
\hline Human Resource & No & -.. \\
\hline Human Resource & No & -. \\
\hline ... & No & -.- \\
\hline -.. & No & -.. \\
\hline -- & Yes & Human Resource \\
\hline -- & No & $\cdots$ \\
\hline $\begin{array}{c}\text { Foundations of } \\
\text { Teaching ... }\end{array}$ & No & -.. \\
\hline
\end{tabular}

\section{Descriptive Summary}

Inquiry Question 10: There were 7 areas where college sources were preferred by more than 40 percent of respondents and 14 areas where workshop sources were preferred by more than 40 percent of respondents.

Inquiry Question 11: There were 18 areas where the value Important was selected by more than 40 percent of respondents.

An analysis of Inquiry Question 1, Table XXXVIII, shows a trend toward a difference in how respondents with different job responsibilities perceive the importance of supply and equipment management. Business administrators rank this area Important 35 percent and Somewhat Important 51 percent of the 
time. Superintendents rated it Important 47 percent and Somewhat Important 38 percent of the time. In the overall ranking, Supply and Equipment Management did not receive a rating of Important more than 40 percent of the time (Table XLVIII).

The trend seems appropriate when considering the superintendents' responsibility to ensure that the educational program is operating effectively. Supplies and equipment are needed in a timely fashion (e.g., black and orange construction paper is needed before October). This trend does help focus the school business official on the primary goal of the educational system: the effective education of students.

Inquiry Question 3 compared the respondents' ages to the importance of the various areas of training. Table $X \mathrm{~L}$ indicates a significant difference in how the older (60-plus) group rates Human Resource Management in importance. Overall, Human Resource Management garnered the second highest ranking (63 percent) for importance (Table XLVIII).

Seventy percent of the over-60 respondents placed a high value on Human Resource Management, but 15 percent considered it Unimportant. This could be a result of management training in the past, the evolution of older SBOs from the role of technician to that of manager, resistance to change, or just the small number ( 3 ) constituting the 15 percent.

Again, the need for those with less authority or experience (presumably younger) to utilize human relations to get things done may cause them to rate 
this area higher.

Implications for this significant difference are somewhat irrelevant if one assumes those who rated Human Resources Unimportant would be retired soon. If those who ranked this area had changed their perceptions over the years, that could be an endorsement for the need for continued professional development. No conclusion as to the reason for this rating is apparent from this survey, but that may be an area for further study or inquiry.

The same difference in Human Resources appeared in the gender comparison of Inquiry Question 4. Table XLI shows a difference because the five respondents that rated Human Resources as Unimportant in the age comparison were all male. Overall, the rating of Human Resources as Important or Somewhat Important was 91 percent for male and 93 percent for female respondents.

The overall rating for Human Resource Management by age groups in the Important or Somewhat Important value (Table XL) dropped steadily with increasing age, although all rated it relatively high. The youngest group rated Human Resource Management as 100 percent Important or Somewhat Important; the 30-39 and 40-49 groups, 94 percent; the 50-59 group, 91 percent; and the 60-plus group, 85 percent. Based on this distribution, it appears that the difference in value for Human Resource importance is related more to age than to gender.

A trend toward a difference is indicated for Inquiry Question 7, Table XL. 
Again, Human Resource Management is rated differently based on the respondent's education. The same five respondents involved in the age and gender analysis show up with graduate-level education and create a polarity of opinion. Of the graduate-level respondents, 92 percent feel Human Resource Management is Important or Somewhat Important. The high school and bachelor's-degree respondents feel likewise, at 86 and 89 percent, respectively. This further indicates that the difference in perception in importance for Human Resource Management is more related to age than to the levels of either education or gender.

The trend indicated in the area of Human Resource Management may also reflect the changing role of the SBO. Older SBOs began their careers in a period when many schools were growing and were adequately funded. In that environment, the SBO role was more that of technical support to keep the operation going. In the past twenty years, that role has continued but has been expanded to include the role of district administrator and budget analyst. As the SBO role broadens from technical to administrative, it might be expected that Human Resource Management would be perceived as essential. No evidence of this is included in this study; however, the changing role of the SBO would be a good area for further investigation.

Table XLVI shows a significant difference in how respondents perceive the Foundations of Teaching and Learning and Staff Development (Inquiry Question 9). There is zero probability that these two areas are rated the same. 
The analysis was made to see if the respondents perceived a relationship between Foundations of Teaching and Learning for children (classroom instruction) and Foundations of Teaching and Learning for adults (staff development).

The distribution indicates that 53 (23 percent) of the respondents valued Staff Development at one of the important levels and Foundations of Teaching and Learning at an unimportant level. Another 21 ( 9 percent) rated both areas at an unimportant level. Conversely, 146 (63 percent) rated both at an important level. Apparently the direct connection of the Foundations of Teaching and Learning to Staff Development is not obvious to all respondents. No significant difference appeared in the analysis of job responsibilities compared to these two variables as shown in Table XXXVIII.

The reason for the difference indicated in Inquiry Question 9 does not appear to be based on demographic variables. Perhaps the lack of connection between Staff Developrnent and Foundations of Teaching and Learning is a perspective that has not been questioned. In developing curriculum to instill a broad perspective of the educational enterprise, the use of staff development as an example seems appropriate. The similarities between education and business management could be studied both within a district or, externally, within the business community. This area is recommended for consideration when expanding the curriculum model.

In Chapter III, anticipated results for two of the research questions were 
noted. Specifically, I expected:

1. Respondents from the West to prefer continuing education or experience for their training, with other geographic areas possibly preferring a preparatory college program.

2. Superintendents and university representatives to consider the Educational Enterprise of higher importance as a training area than SBOs would.

Neither of these expectations was confirmed by a significant difference or even a trend. In fact, a higher percentage (69 percent) of respondents for the U.S. South preferred continuing education and experience over a college preparation program than respondents in the West (62 percent) (Table VII).

When comparing how individuals with differing job responsibilities perceived importance of the educational enterprise, both the business specialist and the business administrator place the Educational Enterprise as Important or Somewhat Important (95 and 89 percent, respectively).

Superintendents ranked this area as Important or Somewhat Important at an 82 percent rate (Table XXXII).

University respondents placed Educational Enterprise in one of the two important categories 89 percent of the time, but more of them (77 percent) than of the other groups (50 percent) selected the important-level value.

Inquiry Questions 10 and 11 were intended to indicate the preference, in rank order, of the sources and importance of the various areas of training identified in the ASBO/Danforth model. Table XLVII indicates that, generally, a 
college preparatory program was preferred (at 24 percent) to a continuing education or workshop source (20 percent). Experience was preferred at a 13-percent rate. A large percentage (43 percent) of the respondents did not answer this question.

In four of the six basic areas, college was the source preferred by over 40 percent of the respondents. The four areas were Educational Enterprise (59 percent), Financial Resource Management (58 percent), Information Management (44 percent), and Human Resource Management (43 percent).

The workshop source of training was preferred by more than 40 percent in only one area: Facility and Property Management (41 percent). In no case did more than 40 percent prefer experience as a source, but 36 percent selected that source in the Management of Ancillary Services area.

The source ranking indicates that a variety of sources is needed. The more general management subjects appear to be best provided by a college setting, while workshops tended to be preferred for the specialty areas (Facility and Property Management and Management of Ancillary Services).

A variety of training sources is not the only flexibility needed. Timing is critical. For illustration, purchasing and warehouse managers strive to bring supplies "just in time" for use. This assures that the inventory doesn't get outdated or tie up resources waiting to be used. The same concept applies to training SBOs. Because of job needs and new requirements, there is no advantage in trying to store everything in the learning inventory of SBOs before 
they start their careers. Some basics need to be there, but many areas of training would be more relevant at the time they are needed.

All six basic areas of training except the Managment of Ancillary Services were considered Important more than 50 percent of the time. However, ancillary services were considered either Important or Somewhat Important by 86 percent of the respondents. All six basic areas averaged a 90-percent perception as Important or Somewhat Important, ranging from 86 to 93 percent (Table XLVIII). No area had a majority of respondents who felt it was Unimportant or Somewhat Unimportant. Only two, Foundations of Teaching and Learning and Real Estate Management, had 30 percent in the two Unimportant ratings. No other specific area had more than 15 percent in these two ratings.

\section{OBJECTIVES REVIEWED}

In Chapter I three objectives of the study were noted. These were to determine:

1. What components of a school business professional-development plan are considered Important to the parties surveyed?

2. What is the preferred source to provide the desired professionaldevelopment training?

3. What similarities and differences in perception exist among those surveyed based on their roles and demographic distinctions? 
The survey provided the information needed to meet these objectives. The results of Inquiry Question 11 serve to validate the ASBO/Danforth model. All areas, general and specific, are considered important by a comfortable majority of the population sampled. There was no single preferred source of training, but rather, a preference for a variety of sources.

Finally, there is a general agreement in the perceptions of those surveyed, regardless of roles or demographic distinctions. This presents strong evidence for a common body of knowledge and a consensus for the sources of professional training to gain that knowledge.

\section{CRITIQUE}

The following critique is offered upon review of the survey and analysis. These observations are intended not to diminish the value of the data gathered but to reflect on the study from a broader perspective.

First, the response from the two smaller sample groups was limited. University respondents totaled 37 of 100 , while 35 of 100 superintendents responded. The number reflects a good percentage response and appears representative. A higher number of responses may have allowed the statistical analysis to be less suspect with less sparse distribution.

Another response limitation was the number of SBOs responding from Canada. Only 16 of the targeted 100 responded. This may have been related to postage costs. The survey had a self-addressed, U.S.-postage-stamped 
envelope enclosed. Some of the responses from Canada had the U.S. postage only. Some had Canadian postage added. Although the Canadian responses are similar to the U.S. responses, acceptance of the conclusions may have less credibility to Canadian SBOs.

The responses also reflected a higher percentage (60\%) from the west and midwest. This may not be representative of the population of SBOs, but no indication of a difference came from the analysis of Inquiry Question 5.

Another limitation is the manual entry of survey data. The data were entered into the SYSTAT program, processed, edited, and reprocessed. There appears to be minimal error, but the locations of the respondents' marks were subject to interpretation by the person entering the data. Also, in the entry format, entry errors are not readily identified.

The categories selected for defining universities were limited. Some universities fit more than one category and no definitive characteristics surfaced that could distinguish one group from another. Perhaps future studies could define the universities by a more measureable characteristic, such as membership in the University Council for Educational Administration.

The sample was selected from ASBO-I members. Since not all superintendents, school business officials, and business specialists are members of ASBO-I, the group may or may not have reflected the larger population of such administrators in Canada and the U.S. It may be helpful to study this further using a survey population based on the total populations of 
each of these groups.

Much more agreement than expected emerged from the study. The apparent agreement is convincing because the study was designed to and expected to create differences. This also helps confirm the goal of the research methodology to be unbiased and objective.

Timing is a factor in the analysis as well. Respondents were asked to project needs into the 1990s. Projecting needs in a time of increasing change is difficult, and most respondents likely responded based on personal experience. This means the results must be considered in the context of being representative of one point in time, not a solution for the future, and definitely not fixed.

General limitations inherent in the survey format must also be considered. The respondents' perceptions of the terminology used was not subject to clarification. No discussion occurs in a survey, and no questions can be answered.

The nature of the SBO job also affects the perceptions reported. Because of the complexity and scope of the SBO role, the tasks performed may occur on a periodic basis. For example, if an SBO or superintendent has not administered a fire claim, built a new school, or sold a vacant school, then the importance of risk-management, facility planning, or real-estate management may be perceived as less important. Also, there may be a tendency to rate the current problems as the most important. For example, although 91 percent 
rated budgeting as Important, ten respondents rated it Unimportant. My assumption is that those ten are comfortably funded at this time.

Preference for a source of training may reflect a respondent's personal experience. If college classes were available in a respondent's past, they may be preferred. If college classes were not available, then the respondent may prefer workshops.

Finally, the responses had a tenor of support and encouragement. The percentage of responses, various comments, and interest expressed during the survey indicated a need exists and help is wanted. The opportunity for improvement exists.

\section{OPEN COMMENTS}

In addition to the research and inquiry questions, respondents were given the opportunity to add comments or categories for training. The comments are listed in Appendix K. As expected, the targeted groups generally support professional development and top management involvement for SBOs.

Other comments indicated difficulty respondents found in selecting just one choice or degree of importance. That frustration was expected. The purpose of the scale was to force a judgment. If the survey had consisted of one question (e.g., Do you think all these areas are important?), some respondents would have been more comfortable; however, little direction would be available for improving the professional development of SBOs. 
The comments generally correlate to the survey results, indicating a variety of sources is needed to meet a variety of needs. One comment focused on an area not usually considered a subject for professional development: integrity. Personal values are not identified in the model, but as indicated in Chapter II, a code of ethics is considered a criterion for a profession.

Few respondents mentioned specific traits or skills of a general nature, such as common sense, good judgment, creative thinking, and problem-solving abilities. The absence of such topics does not mean they are not needed. Rather, the nature of the model validation was more subject-specific, and the respondents likely assumed that skills of this nature are inherent in the management functions.

Appendix $L$ summarizes the additional categories suggested. The three areas that received more than one suggestion were:

1. Politics.

2. Ethics.

3. General management.

These were not directly associated with the categories of the ASBO/Danforth model but are implicit in effectively performing the functions of an SBO.

The conclusion from the comments and added categories is that school business is not a distinct discipline with unique skills. Rather, school business is a system of integrating and balancing management, personal values, the 
environment, and politics, while applying a multitude of more specialized skills and broader knowledge. School business is a very challenging profession.

\section{SUMMARY}

This study sought the validation of the ASBO/Danforth curriculum model through specific research and inquiry questions. A survey was developed and sent to 666 representatives with a vested interest in school-business professional development; and 251 responded. Differences among respondent characteristics were sought through a chi-square analysis and interpretation. The conclusions were documented based on the survey results. Qualitative responses were also reviewed and observations made.

As a result, recommendations for developing effective professionaldevelopment programs for SBOs are offered. These recommendations, both in general and by specific interest group, are based on information developed in this study and are presented as the conclusion of the study.

\section{GENERAL RECOMMENDATIONS}

The evidence expressed in the survey indicates that respondents from all job responsibilities, locations, experiences, ages, gender, and district or university characteristics agree with the importance of professional development in the areas indicated in the ASBO/Danforth model. Based on this agreement, three general recommendations are presented for the 
consideration of all those affected by SBO professional development.

1. Accept the ASBO/Danforth model as the foundation for developing college course work and workshops for SBOs in both the United States and Canada. This would provide a common base for development of programs, facilitate sharing successful programs, and enhance advancement opportunities for SBOs between states and provinces.

2. Address personal characteristics in the training program. School business administration operates within a system of interrelating environments. SBOs must balance multiple customer needs and maintain integrity while performing various technical skills. As indicated in the open comments, an effective SBO must have and be reminded of the necessary personal characteristics to maintain that balance.

3. Increase public awareness of the requirements of the SBO training needed. The expected shortage of SBOs will demand job candidates and informed employers. By increasing awareness of the requirements of the model, school boards and superintendents will have a better understanding of the knowledge and skill requirements to be assessed when hiring SBOs. Further, with the maturation of the existing SBO work force, new recruits are needed. Even the most qualified candidates will need to know about the profession and its critical role in school-district operations before applying for an opening. 


\section{RECOMMENDATIONS FOR SUPERINTENDENTS}

In reference to training SBOs, superintendents should:

1. Understand the scope and complexities of the SBO position as identified in the ASBO/Danforth model.

2. Support professional development for SBOs and staff that addresses the components identified in the model.

\section{RECOMMENDATIONS FOR UNIVERSITIES}

In reference to training SBOs, university or college departments of education administration should:

1. Incorporate into the university curriculum classes preferred by SBOs, as indicated in Table XLVII.

2. Help increase the awareness of school business functions by identifying the components of the ASBO/Danforth model in superintendent and principal professional-development programs.

\section{RECOMMENDATIONS FOR SCHOOL BUSINESS ASSOCIATIONS}

Each school business association, whether local, regional, or international, should make efforts to enhance the professional development of SBOs by:

1. Incorporating the workshops preferred by SBOs, as indicated in Table XLVII, into the professional development programs offered at local, 
regional, and international levels.

2. Helping increase awareness of school business by initiating activities to keep professional development as a priority in education. This could include taking a leadership role in encouraging and coordinating efforts for improved professional development. Another option would be to provide a front-end investment for program curriculum development and make the results available throughout the association.

\section{RECOMMENDATIONS FOR SCHOOL BUSINESS OFFICIALS}

SBOs should:

1. Understand the complexities and components of school business as identified in the ASBO/Danforth model.

2. Use the model to develop and execute a personal formalized training program to assure competency and professionalism in school business.

\section{OBSERVATIONS}

During the analysis of the data, observations not directly related to the study were made. These reflected the questions raised by the analysis as well as the author's experience. These are offered in the same categories as the recommendations: in general, and by specific interest group.

General observations or suggestions include:

1. Continue to develop school business administration as a profession. 
This study confirms that there is a common body of knowledge. A model for a formal standardized training program has been provided by the ASBO/Danforth Task Force. The next step is to develop that model into a program. This can be done by defining the competencies needed for an effective SBO and developing a variety of sources to provide the necessary training. It appears that there is agreement, at least among the sampled ASBO-I membership, for proceeding with the model.

2. Establish professional-development networks. With the common agreement on needs and areas of training, each province and state should be able to integrate and adapt training from other areas. Sharing and support would not only be cost effective, but would allow improvement of existing programs and facilitate upgrading the profession as quick!y as possible.

3. Integrate school business into the business community. There are interchangeable skills where training is already available. Public administration, hospital administration, and hotel management share many common areas with school business. As indicated earlier, a variety of sources is needed. These should not be limited to just school business classes or workshops. Business partnerships provide options for shared support that can be customized to local situations.

4. Look to the future. Be flexible, expect change, and meet the various needs of the future with new alternatives. What was successful in the past may not work in the future. What was confirmed in this study will change as well. 
Watch for trends.

5. Do something now. Don't wait for the perfect answer. There is no single answer to professional development. SBOs have a better chance of enhancing their profession by looking for ways to improve instead of waiting for someone else to tell them what to do.

Observations and suggestions specifically for superintendents are:

1. Mentor the SBO in the educational, political, and general management arenas to supplement classes and workshops.

2. Seek and hire candidates for school business positions who are qualified in all components of the model.

Universities could help formalize professional training for SBOs by:

1. Participating in establishing professional development networks by coordinating offerings among other disciplines, such as business and public administration programs.

2. Cooperating with associations, state agencies, districts, and other interested groups to provide services to help in staff and professional development.

3. Working with school business practitioners to identify the changing needs for school business professional development.

4. Being flexible in credits, class times, locations, and types of training, to meet the needs of the students.

Observations and suggestions for school business associations include: 
1. Prepare for the future by identifying the needs and the changing roles of their customers. This could be done by periodic surveys to see if the training now provided by the association is relevant and to see how the association could help improve professional development. The associations of the future may not be able to rely on one annual conference for information exchanges. Technology, travel costs, and time pressures for change all encourage associations to consider options such as regional meetings. Associations may need to decentralize or co-opt or diversify to survive.

2. Participate in establishing professional development networks by brokering information on professional development for SBOs. This service could include establishing video and data exchanges, hosting symposiums of universities, agencies, and other associations to pool resources as well as encouraging publication of professional-development material.

3. Associations should emphasize the professionalization of SBOs and provide training for all SBOs, not just for association members. This would offer a valuable service to not only current association members but also to nonmembers. The result would meet two key objectives: to improve the training level within the profession; and to encourage the recruitment of new members, who would then become the resources for future professional enhancement.

Finally, SBOs might help upgrade their profession by:

1. Considering themselves as educators. Whether you are educating 
children, adults, or yourself, you are an educator. The principles of education and management are similar. To know both areas will enhance the effectiveness of an SBO. The SBO should develop support-service staff, participate in personal development, and share with others.

2. Considering themselves as professionals. The role of SBO is changing steadily. The requirements of the job are increasingly complex. The needs change, and formal professional training is needed if SBOs are to keep current--and that requires the commitment, or calling, of a professional.

3. Finding out what is needed by their customers. Marketing is the process of finding out what is needed by the customer and providing it. SBOs will not improve their profession by telling others the importance of school business. The SBO is not the district "conscience" but a facilitator of the support needed to help the education process. School business is a "service" business.

4. Retaining perspective. In recognition of the complexity and changing nature of the SBO role, SBOs must remain flexible and keep balance in their lives. This will allow them the energy to keep going and the ability to see the big picture.

5. Staying focused on the big picture. SBOs are part of the educational management team. The focus is effective education of children.

SBOs have a lot to do. In general, they do their jobs well with limited training and resources, and make a difference. With a formal, standardized, 
timely training program, they could provide even more support for the education of children.

\section{IMPACT}

The key question to be answered at the conclusion of this study is: What difference can this study make? In a school system, as any organization, change occurs. Whether the change comes from within, such as from an improvement project, or from outside, such as under a tax-limitation measure, the organization needs focus, new alternatives, and trust. This study offers all three.

The ASBO/Danforth Model proposes an international, standardized training program, the focus of which includes the "big picture" of educational administration, not just technical components.

The recommendation to create awareness of school business does not presume change, however, it is a first step and helps to encourage the relevant special interest groups to take that step.

This study also provides direction for training alternatives. The broad scope of topics identified in the model emphasizes the need for alternatives not only in delivery models but in timing as well. As noted earlier, the "just in time" concept of education assures that the training will be there when relevant and needed.

A critical service the SBO can provide is to analyze the effectiveness of 
new alternatives. The SBO trained under the ASBO/Danforth Model can assist educational-policy makers in determining which alternatives, including those in current use, provide the greatest returns on investment (dollars or time).

Finally, the development of qualified SBOs would be an essential link in building trust in school budgets. Qualified SBOs are better able to provide both optimum stewardship of entrusted funds and the most effective use of their own time. Further, the climate of security that can be generated by a qualified SBO helps other employees focus on their primary responsibilities rather than on the budget.

What difference can this study make? It provides focus for school business development, alternatives for providing that development, and the opportunity to promote trust in school business.

\section{FUTURE DIRECTION}

The future direction of school business depends on all the special groups identified. A clear distinction between knowledge and wisdom is that the former is the comprehension of facts, the latter involves action. If the people affected should accept the model as a foundation and start building professional-development programs, the knowledge has proved worthwhile. If, on the other hand, no action were taken, the model will have been an exercise in futility, merely a record of what might have been.

The latter fate has been avoided to a degree by the spring 1992 
implementation of a series of Portland State University school-business classes, developed in conjunction with the Oregon Association of School Business Officials. These classes supplement existing college course work in educational, public, and business administration in order to cover the basic model components. By title, these classes cover Principles of School Business, School District Financial Operations, Managing School Facilities, Auxilliary Services, and Computing and Information Technology in Education.

Even if development should occur as recommended in this study, program availability carnnot automatically guarantee success in school business professionalism. That would require, in addition, that school business officials have the motivation and commitment to acknowledge the broad perspective of educational leadership and to become lifelong students of their profession. 


\section{REFERENCES}

Achilles, C.M. (1988). Unlocking some mysteries of administration and administrators preparation: a replacement prospect. In Griffiths, D.E. Stout, R.T., \& Forsythe, P.B. (Eds.). Leaders for America's schools. (pp. 41-67). Berkeley, CA: McCutchan.

Ammons, D.N., \& King, J.C. (1982). Professionalism and local government administration. American review of public administration. pp. 386-401.

Arizona Department of Education. (1989, January). State Board of Education/Nocational Education certification rules and regulations. pp. 13-14.

Ary, D., Jacobs, L.C., \& Razavich, A. (1985). Introduction to research in education. Fort Worth, TX: Holt, Rinehart and Winston, Inc.

ASBO of Alberta. (1989). The certification of school business officials.

ASBO of Maryland-District of Columbia. Registered school business official/administrator requirement and application sheet.

Benveniste, G. (1987). Professionalizing the organization. San Francisco: Jossey-Bass Publishers.

Bogdan, R.C., \& Biklen, S.K. (1982). Qualitative research for education: an introduction to theory and methods. Boston: Allyn and Bacon.

Buskey, J.H. (1987). Utilizing a systematic program planning process. In Gessner, Q.H. (Ed.). Handbook on continuing higher education. New York: American Council on Education and MacMillan. (pp. 103-124).

California ASBO. (1989). The certification of school business officials.

Callahan, R.E. (1962). Education and the cult of efficiency. Chicago: The University of Chicago Press.

Candler, A.C., Sparkman, W.E., \& Madeley, G.R. (1987, July). Job perceptions of school business officials. School Business Affairs,

pp. 13-16, 18, 19. 
Candoli, C., Hack, W.G., Ray, J.R. \& Stollan, D.H. (1984). School business administration. Boston: Allyn and Bacon.

Cooperman, S. (1989, June 7). Proposed amendments to N.J.A.C. 6:3-1.18 and 6:11-10.4 through 6:11-10.14 certification of school business administrators. Unpublished letter to New Jersey State Board of Education.

Cross, K.P. (1982). Adults as learners. San Francisco: Jossey-Bass.

Dierdorff, W.H. (1985). Oregon establishes guidelines for professional development of school business Officials. School Business Affairs, 51 (10), pp. 44-45.

Dierdorff, W. H. (1988, July). Formal standardized training: the last step to professionalization of school business officials. School Business Affairs, pp. 10-17.

Dillman, D. A. (1978). Mail and telephone surveys. New York: John Wiley \& Sons.

Dingwall, R., \& Lewis, P. (1983). The sociology of professions. London: MacMillan Press Ltd.

Drake, T.L. (1990, March). State requirements for school business officials. School Business Affairs, pp. 18-22.

Educational Research Service. (1982). Needs assessment of ASBO members. 1981-82. Park Ridge, IL: ASBO.

Everett, R.E., \& Everett, J.B. (1988, March). Certification and the school business official. School Business Affairs, pp. 13-16, 18, 19.

Fuller, M. (1987). The supervisory officer in Ontario. Toronto, ON: Queen's Printer for Ontario.

Gessner, Q.H. (1987). (Ed.). Handbook on continuing higher education. New York: American Council on Education and Macmillan. pp. 33-49.

Griffiths, D.E., Stout, R.T., \& Forsythe, P.B. (Eds.). (1988). Leaders for America's schools. Berkeley, CA: McCutchan. 
Hawkins, S.F., and Rebore, W.T. (Eds.). (1991). Model preparation program for school business administrators. Reston, VA: Association of School Business Officials International.

Hentschke, G.C. (1986). School business administration. Berkeley, CA: McCutchan.

Hill, F.W. (1982). The school business administrator. Park Ridge, IL: ASBO.

Houle, C.O. (1980). Continuing learning in the professions. San Francisco: Jossey-Bass.

Jordan, K.F., McKeown, M.P., Salmon, R.G., \& Webb, L.D. (1985). School Materials and methods in adult and continuing education. (pp. 45-49). Los Angeles: Klevins Publications.

Keane, P. (1987). Continuing professional education. In Klevins, C. (Ed.). Materials and methods in adult and continuing education. (pp.45-49). Los Angeles: Klevins Publications.

Kentucky State Board of Higher Education. (1986, June). Kentucky Administrative Regulation (704 KAR 20:110). p. 13.

Kerlinger, F.N. (1986). Foundations of behavioral research. New York: Holt, Rinehart and Winston.

Klevins, C. (Ed.) (1987). Materials and methods in adult and continuing education. Los Angeles: Klevins Publications.

Knezevich, S.J., \& Fowlkes, J.G. (1960). Business management of local school systems. New York: Harper \& Bros.

Knox, A.B. (1987). Helping adults learn. San Francisco: Jossey-Bass.

Larson, M.S. (1977). The rise of professionalism. Berkeley, CA: University of California Press.

Long, H.B. (1983). Adult and continuing education. New York: Teachers College Press.

McGowan, R.P. (1982). The professional in public organizations: lessons from the private sector? American Review of Public Administration, $16(4)$, pp. 337-348. 
McGuffey, C.W. (1980). Competencies needed by chief school business administrators. Park Ridge, IL: Association of School Business Officials.

McLagen, P.A. (1978). Helping others learn. Reading, MA: Addison-Wesley.

Michigan School Business Officials. (1986). Michigan school business official professional certification.

Minnesota State Department of Education. (1975). Certificates, administrators and supervisors. In EDU 329. (pp. 205-206).

Montana ASBO. (1989). A voluntary professional certification program for school business officials. Bozeman, MT.

Moore, S.A. (1990, June). Don't wait too long to prepare your future business officer. School Business Affairs, 56 (6), pp. 39-40.

Moore, W.E. (1970). The professions: roles and rules. New York: Russell Sage Foundation.

Moyer, L.E. (1985). The ASBO chronicles. Reston, VA: ASBO International.

National Center for Educational Statistics. (1992). Digest of Educational Statistics. Washington, DC: U.S. Department of Education.

Nelson, D.L., \& Purdy, W.H. (1971). School business administration. Lexington, MA: Heath Lexington Books.

Nave, G. (1992). SYSTAT 5 Reference Sheet. Unpublished manuscript. Portland State University, Center for Urban Research in Education.

North Carolina State Board of Education. (1986, July 1). Professional certification program for North Carolina school finance officers.

Northern Illinois University. (1990). General information and regulations, masters degree in school business management. (Information brochure). DeKalb, IL.

Ohio State Board of Education. (1987, July 1). Rules for school treasurer (3301-5-01) and school business manager (3301-6-01) license.

Pavalko, R.M. (1971). Sociology of occupations and professions. Itasca, IL: F.E. Peacock Publishers Inc. 
Pavalko, R.M. (1972). Sociological perspectives on occupations. Itasca, IL: F.E. Peacock Publishers Inc.

Raelin, J.A. (1986). The clash of cultures. Boston: Harvard Business School Press.

Riggs, R.R. (1982). The professionalization of the public service: a roadmap for the 1980s and beyond. American Review of Public Administraton, (16), pp. 349-367.

Rivera, W.M. (1987). Organizing effective programs, teaching and learning: overview. In Klevins, C. (Ed.). Materials and methods in adult and continuing education. (pp. 141-143). Los Angeles: Klevins Publications.

Simpson, E.L. (1987). An interactive model of program development. In Klevins, C. (Ed.). Materials and methods in adult and continuing education. (pp. 154-160). Los Angeles: Klevins Publications.

State University of New York College at Brockport. (1990). Certificate of advanced study degree in school business administration. (Information brochure). Department of Education administration.

Texas ASBO. (1988). Professional certification program. Austin, TX.

Vollmer, H.M., \& Mills, D.L. (1966). Professionalization. Englewood Cliffs, NJ: Prentice Hall, Inc.

Wagner, I.G. (1990, January). Vanishing business officials. The American School Board Journal, 25-27.

Wisconsin Department of Public Instruction. (1983, November). Certification requirements for school business managers. Madison, WI. 
APPENDIX A

ASBO-I/DANFORTH

MODEL PREPARATION PROGRAM

FOR SCHOOL BUSINESS ADMINISTRATORS 


\section{ASBO-I/Danforth \\ Model PreparationProgram \\ For School Business Administrators}

I. The Educational Enterprise
A. Foundations of Teaching \& Learning
B. Organization \& Administration
C. Public Policy \& Intergovernmental Relations
D. Legal Aspects

II. Financial Resource Management
A. Principles of School Finance
B. Budgeting \& Financial Planning
C. Accounting, Auditing \& Financial Reporting
D. Cash Management/Investments \& Debt Management

III. Human Resource Management
A. Personnel \& Benefits Administration
B. Staff Development
C. Labor Relations/Collective Bargaining
D. Human Relations

IV. Facility \& Property Management
A. Planning \& Construction
B. Maintenance \& Operations
C. Purchasing 
D. Supply \& Equipment Management

E. Real Estate Management

V. Information Management
A. Strategic Planning
B. Program Evaluation, Research \& Analysis
C. Communications
D. Management Information Systems

VI. Management of Ancillary Services
A. Risk Management
B. Transportation
C. Food Services
D. Health \& Safety
E. Other 
APPENDIX B

SCHOOL BUSINESS REFERENCES

COMPARED TO ASBO/DANFORTH MODEL 


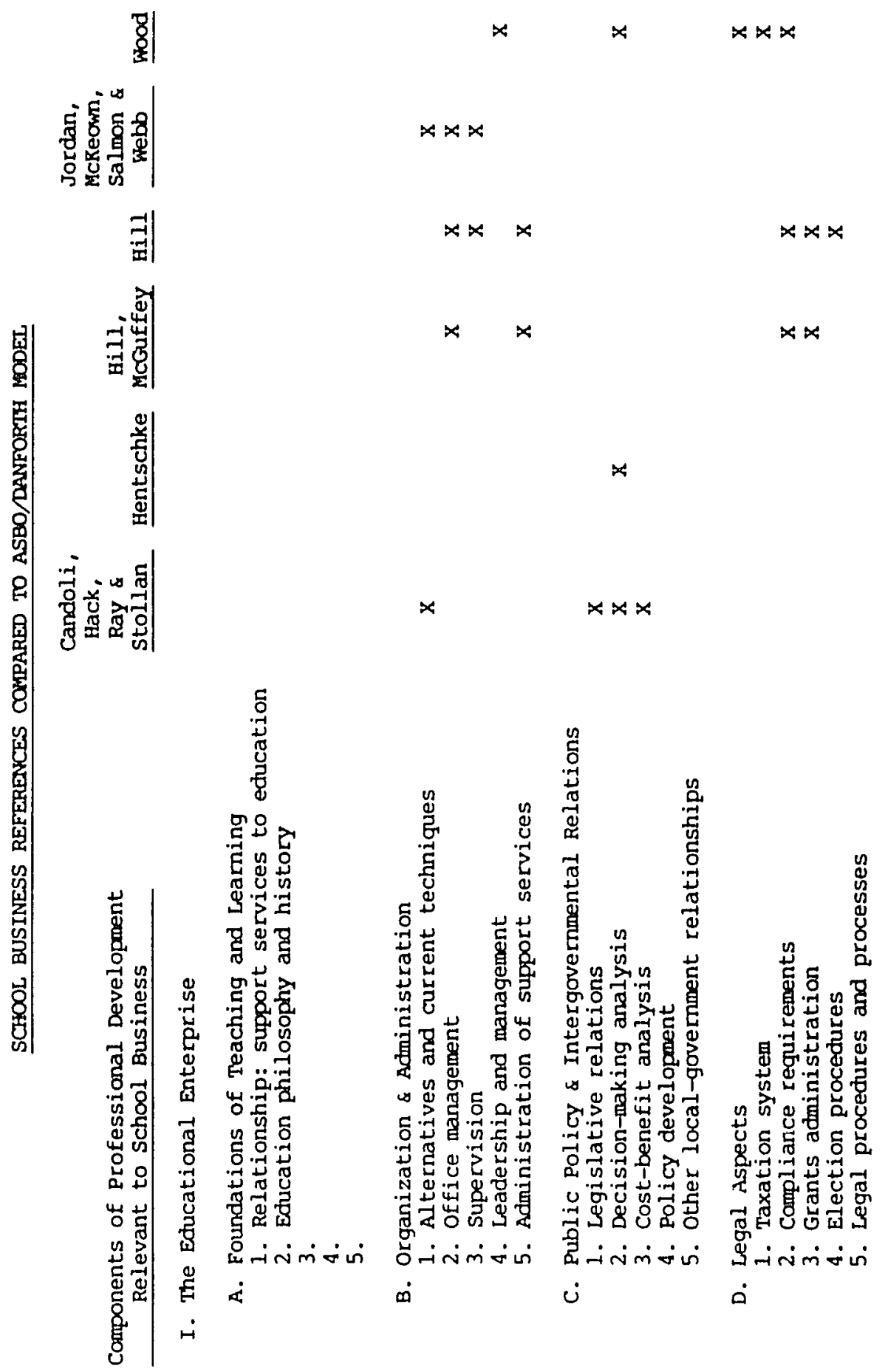




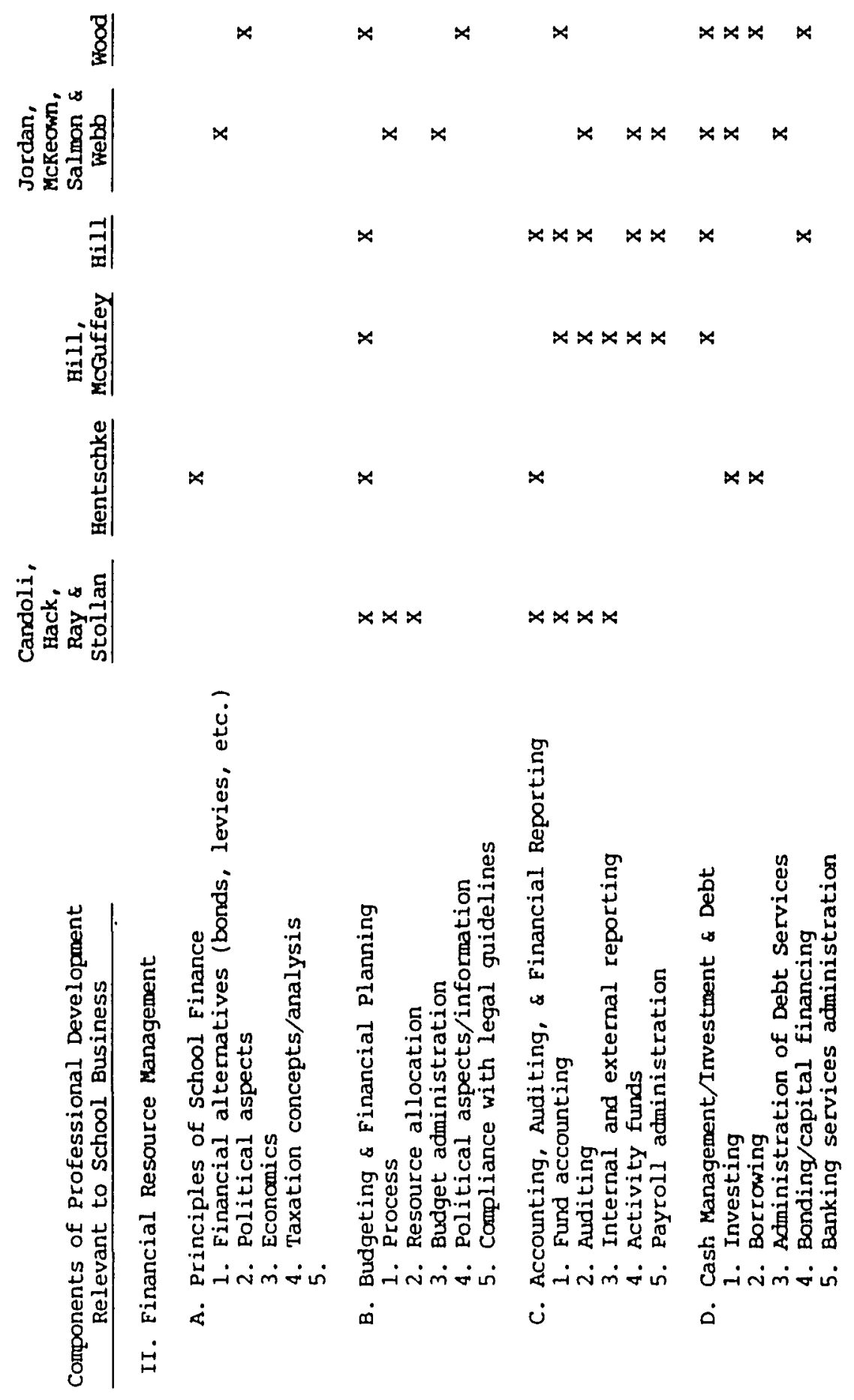



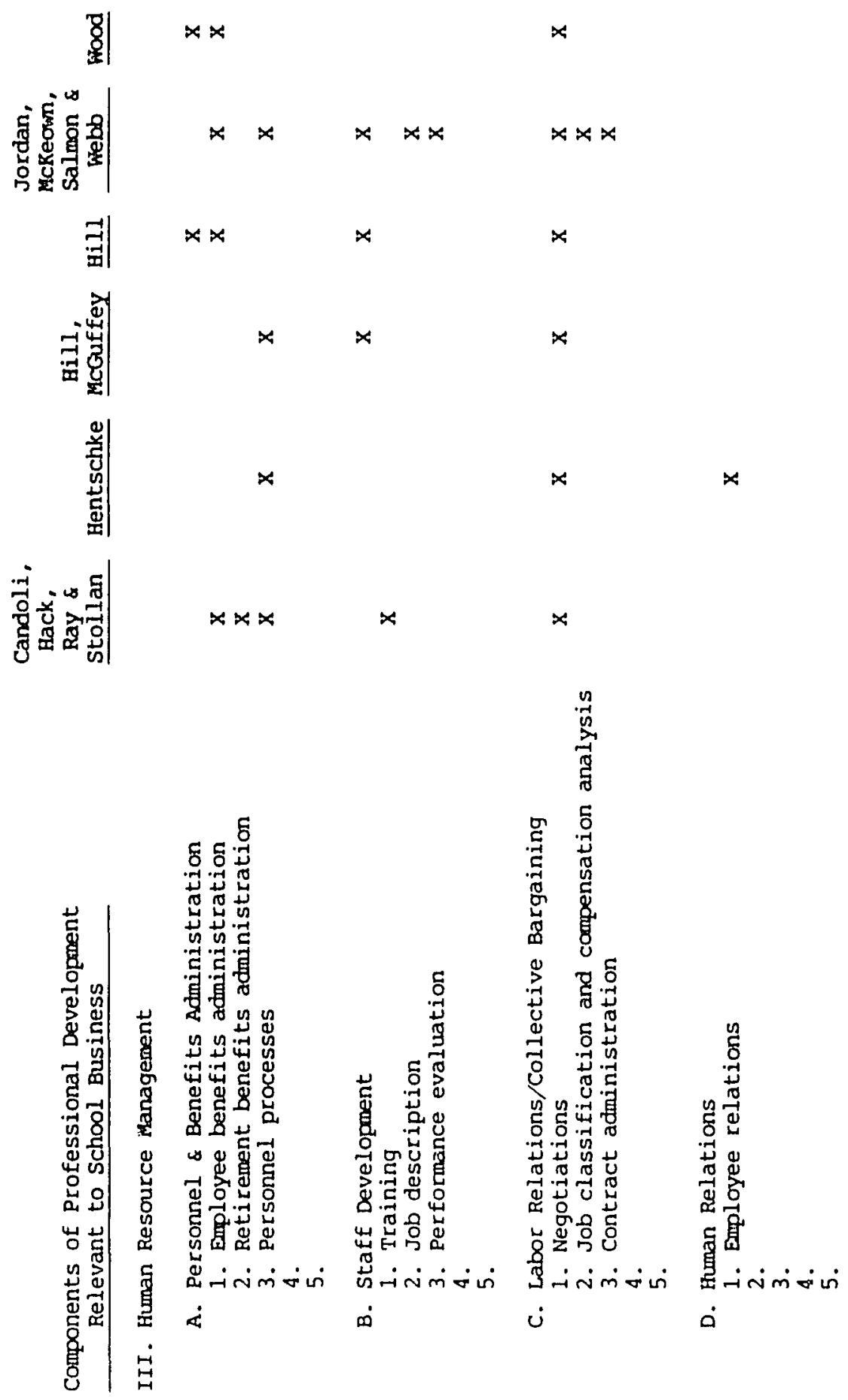

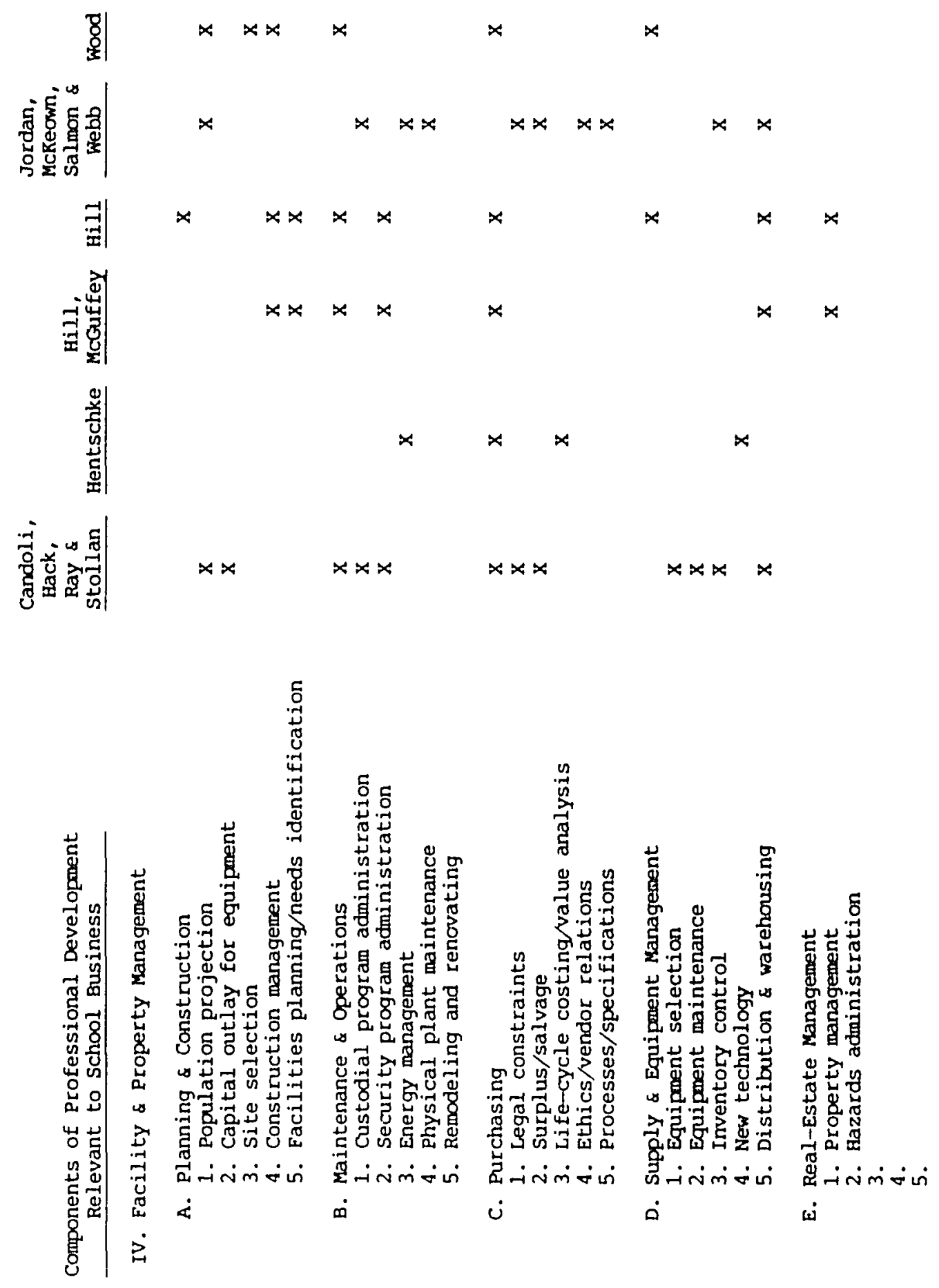

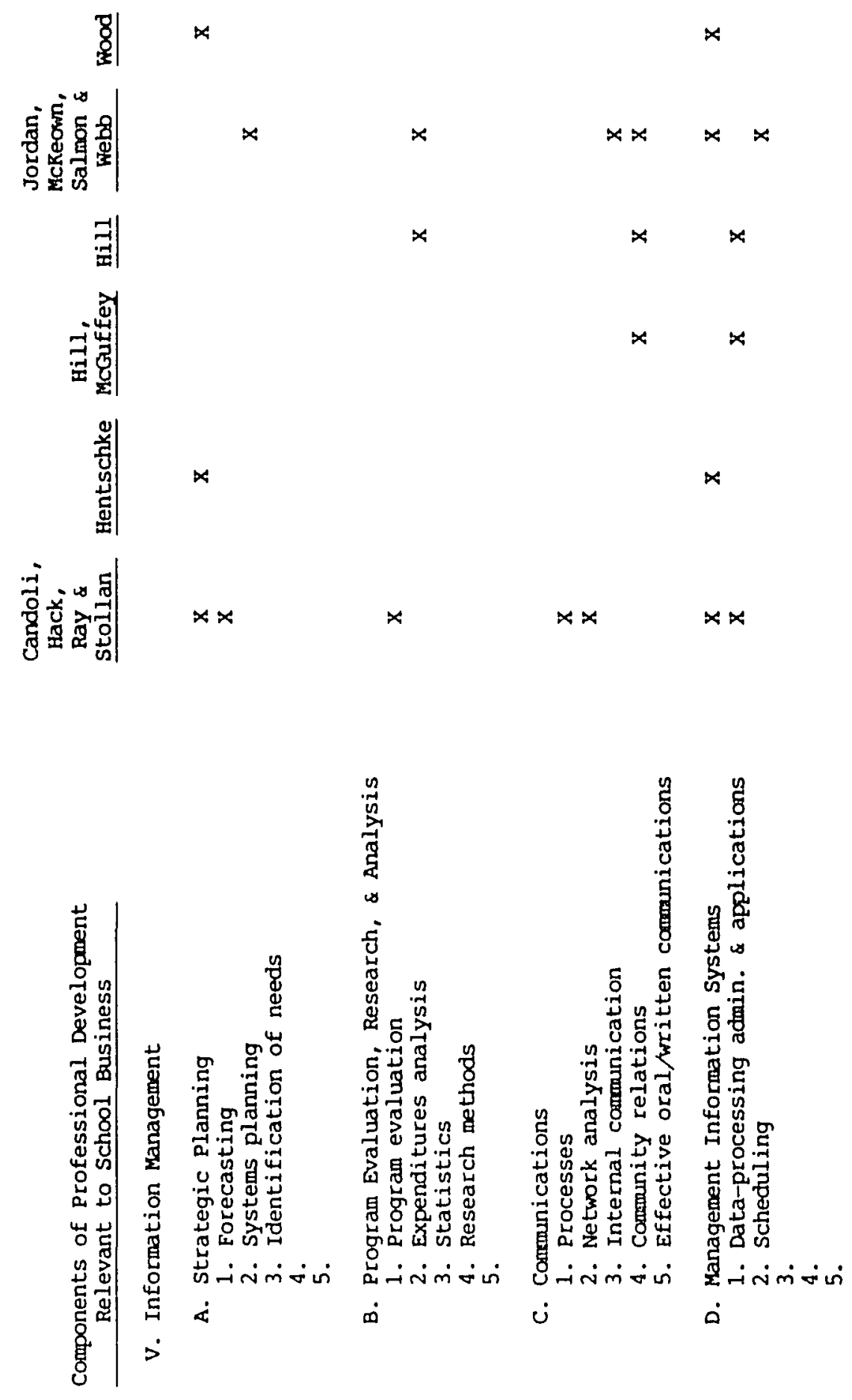

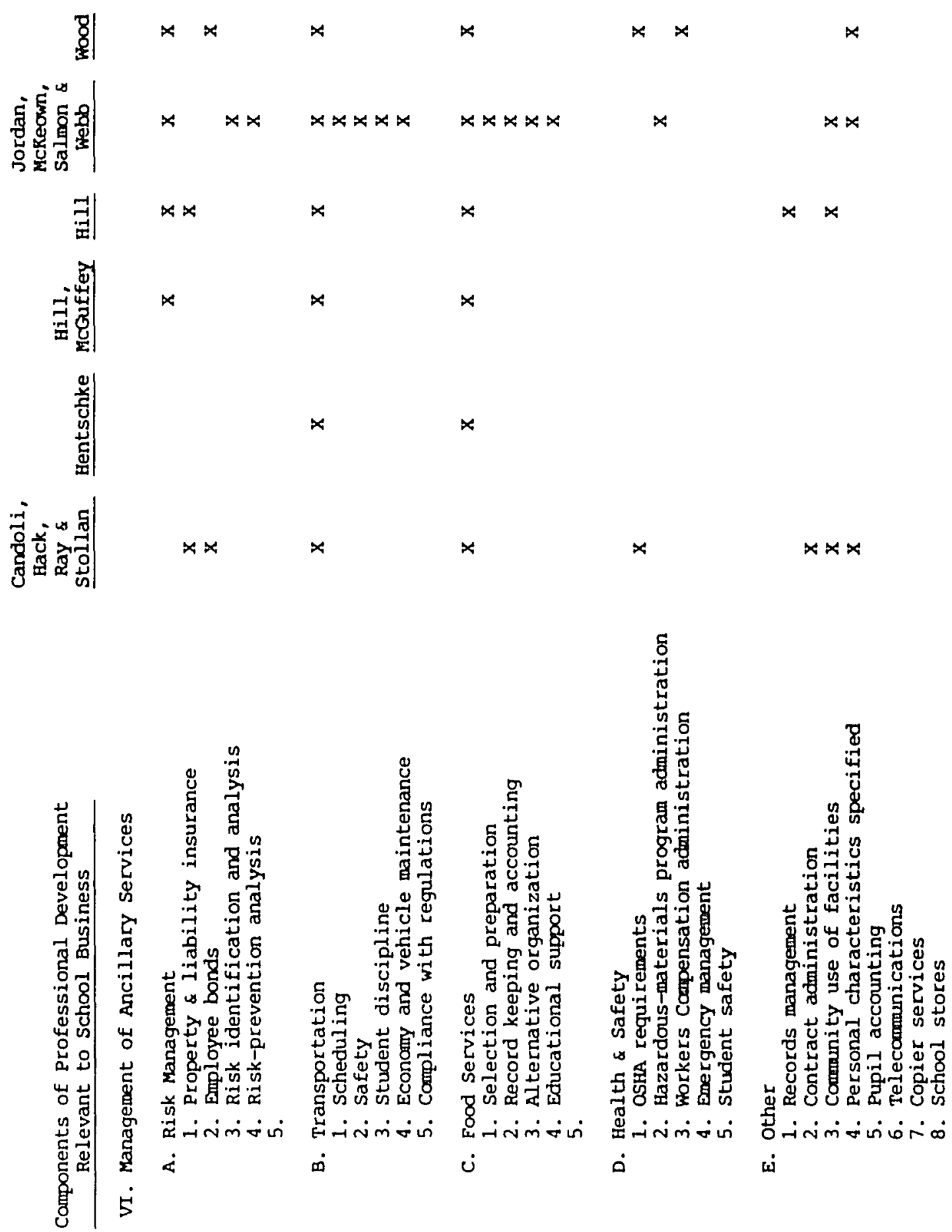


\section{APPENDIX C}

\section{EXISTING SCHOOL-BUSINESS-OFFICIAL TRAINING MODELS}

COMPARED TO ASBO/DANFORTH MODEL 


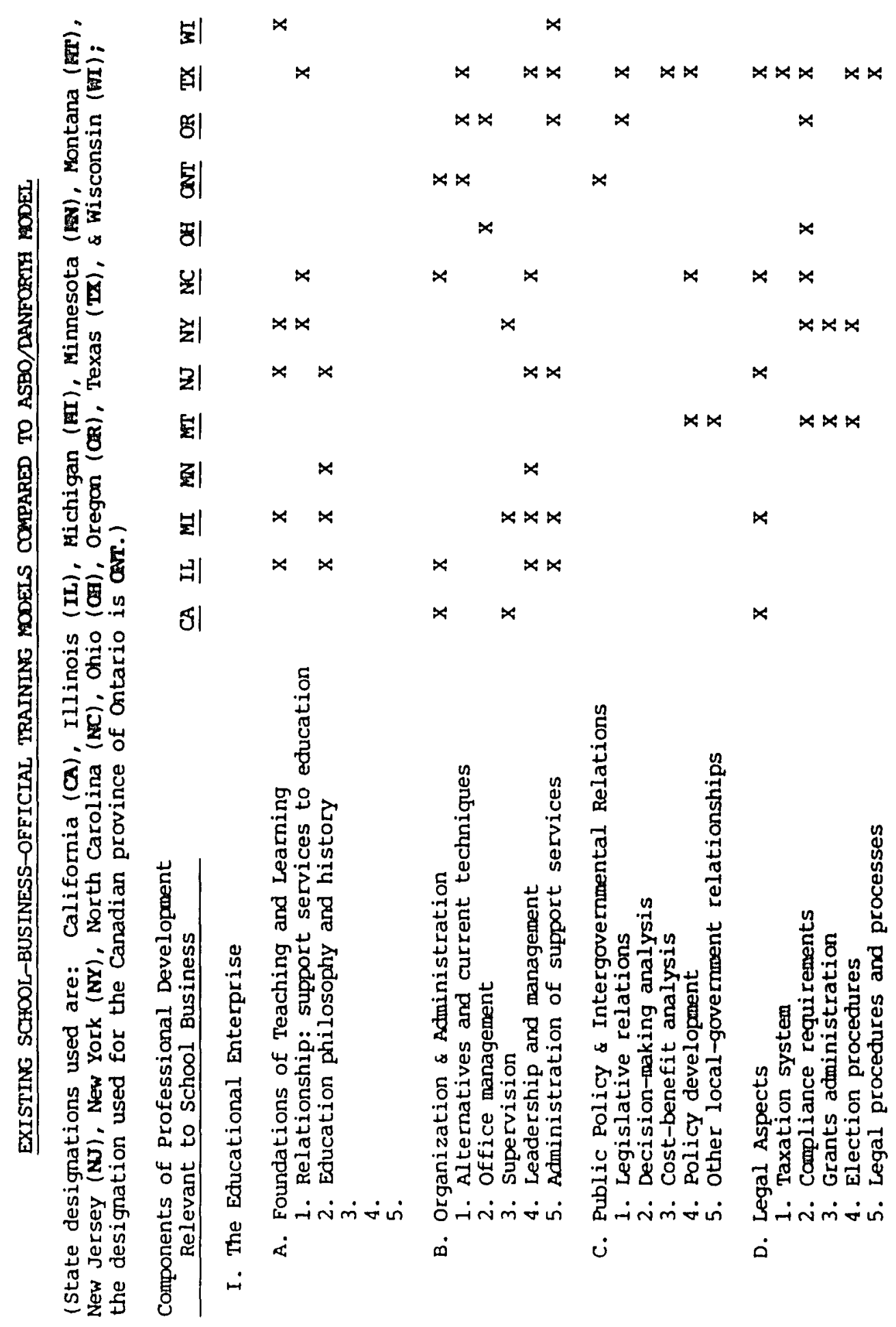




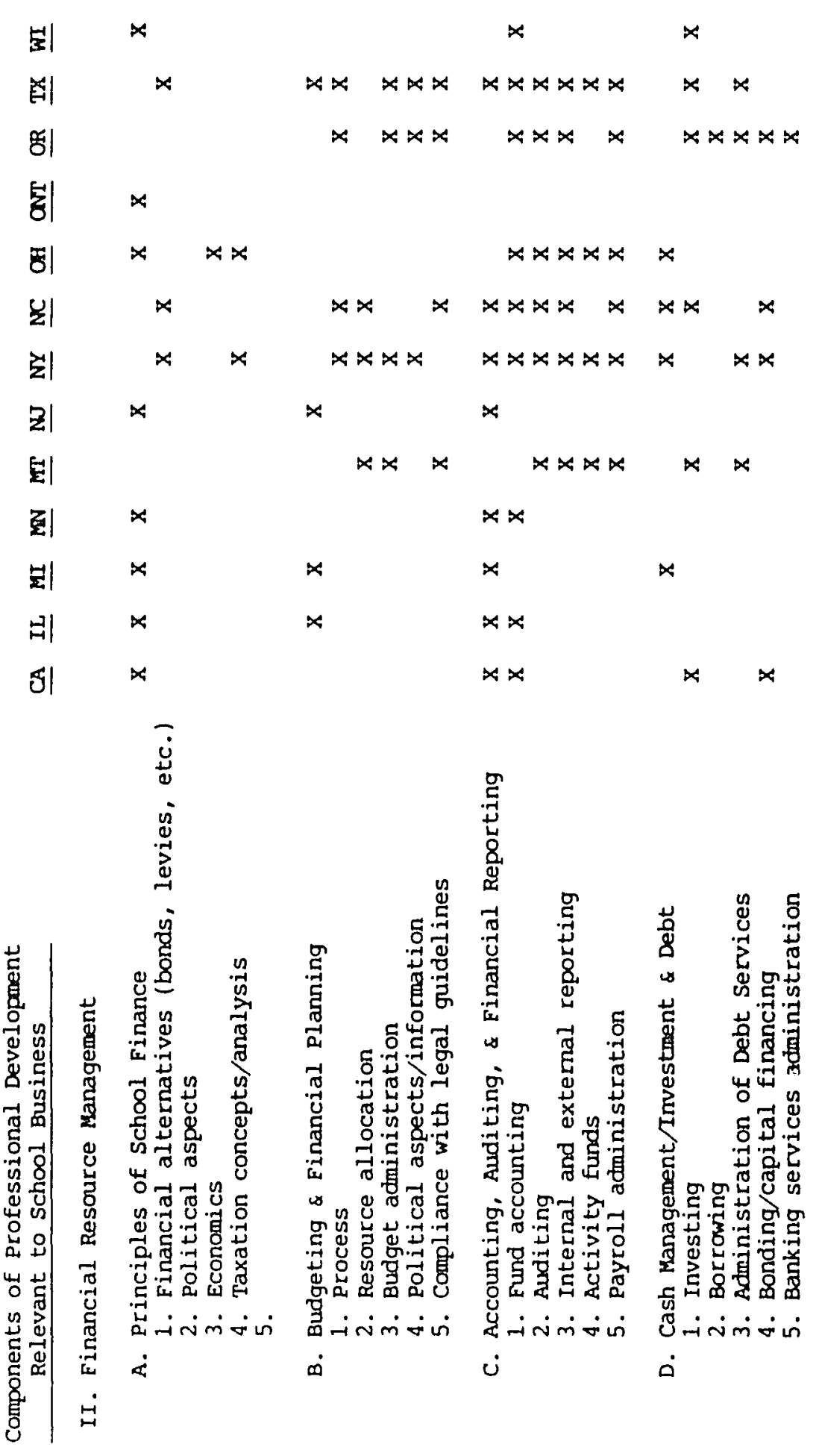



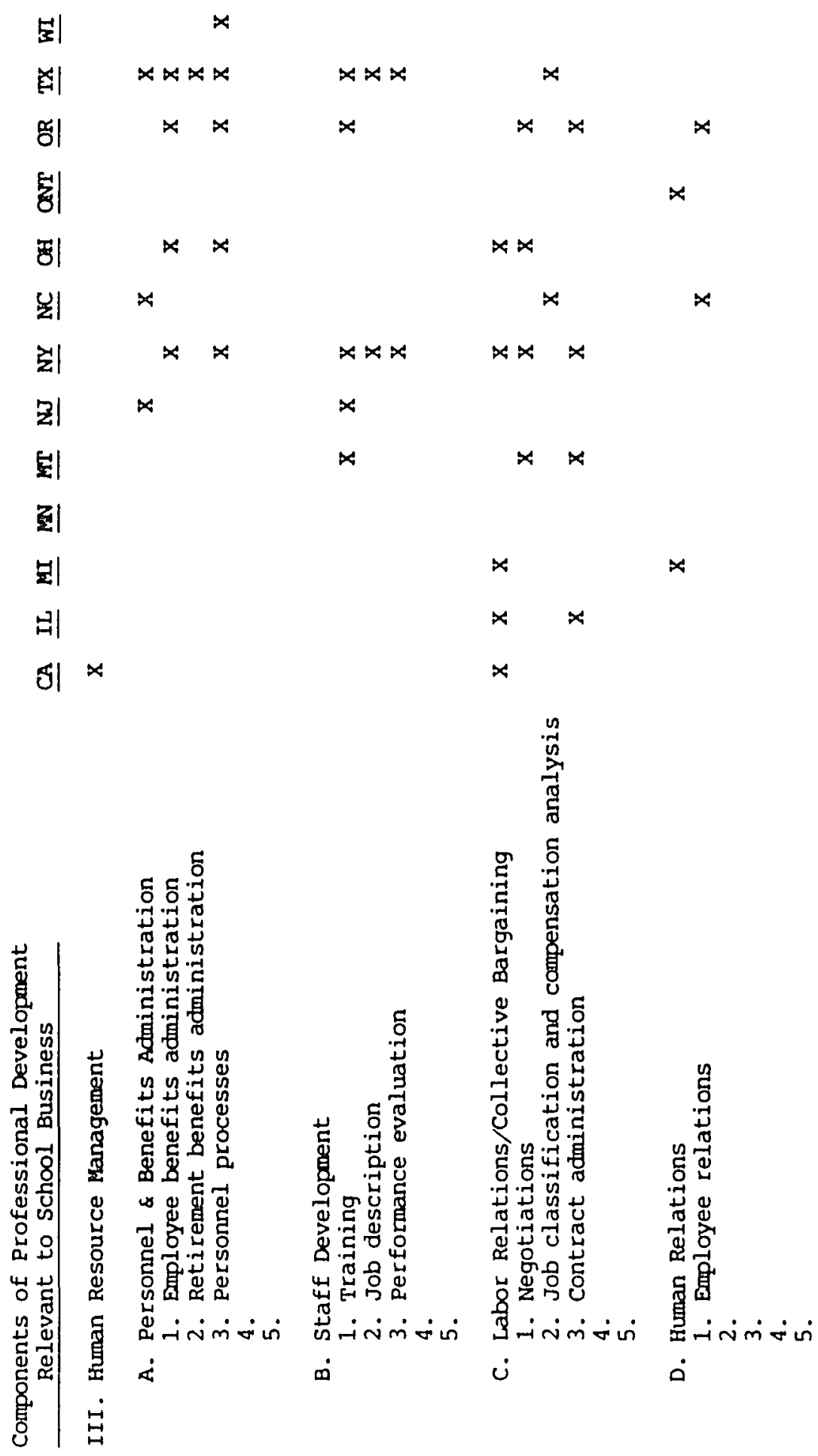

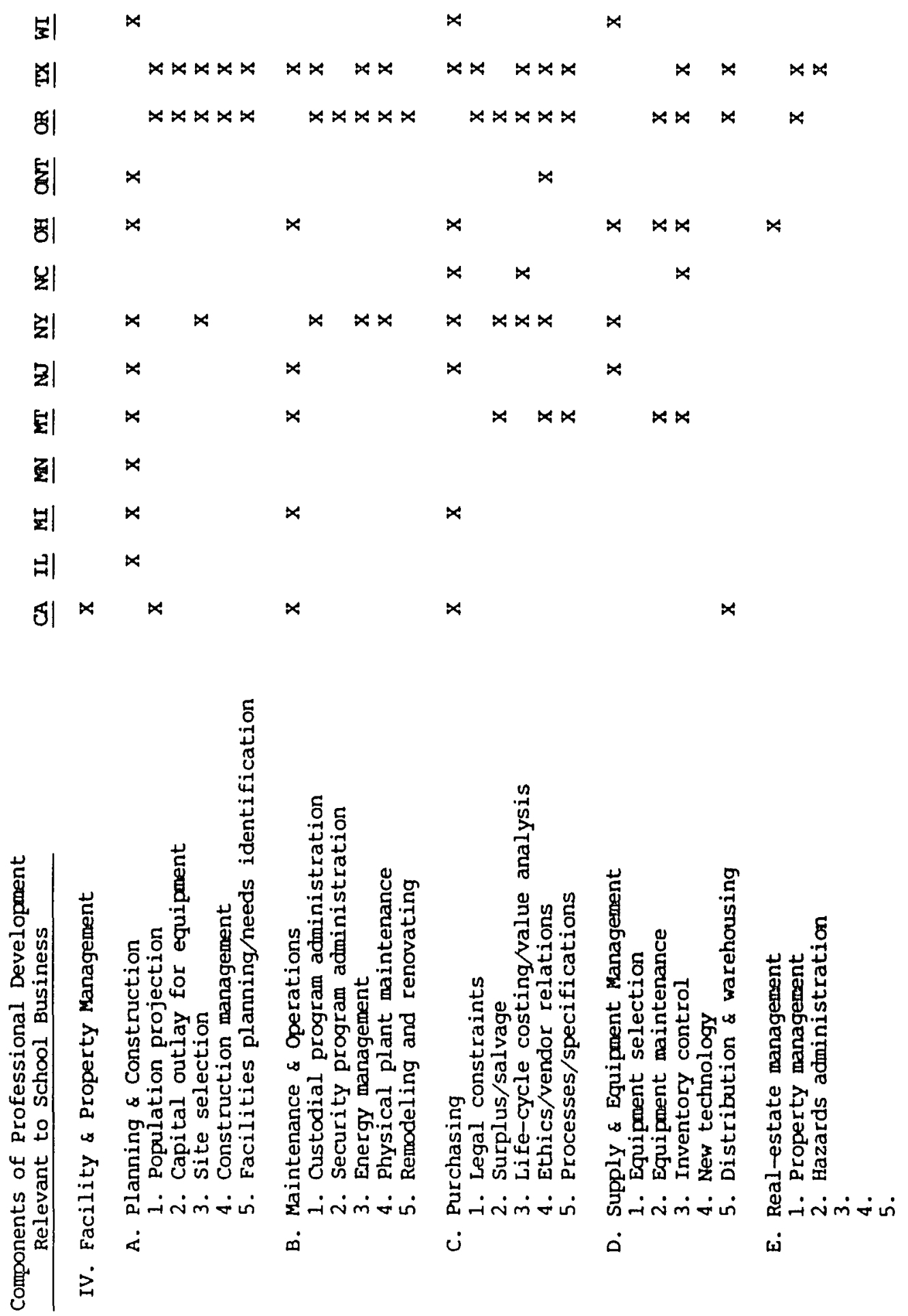

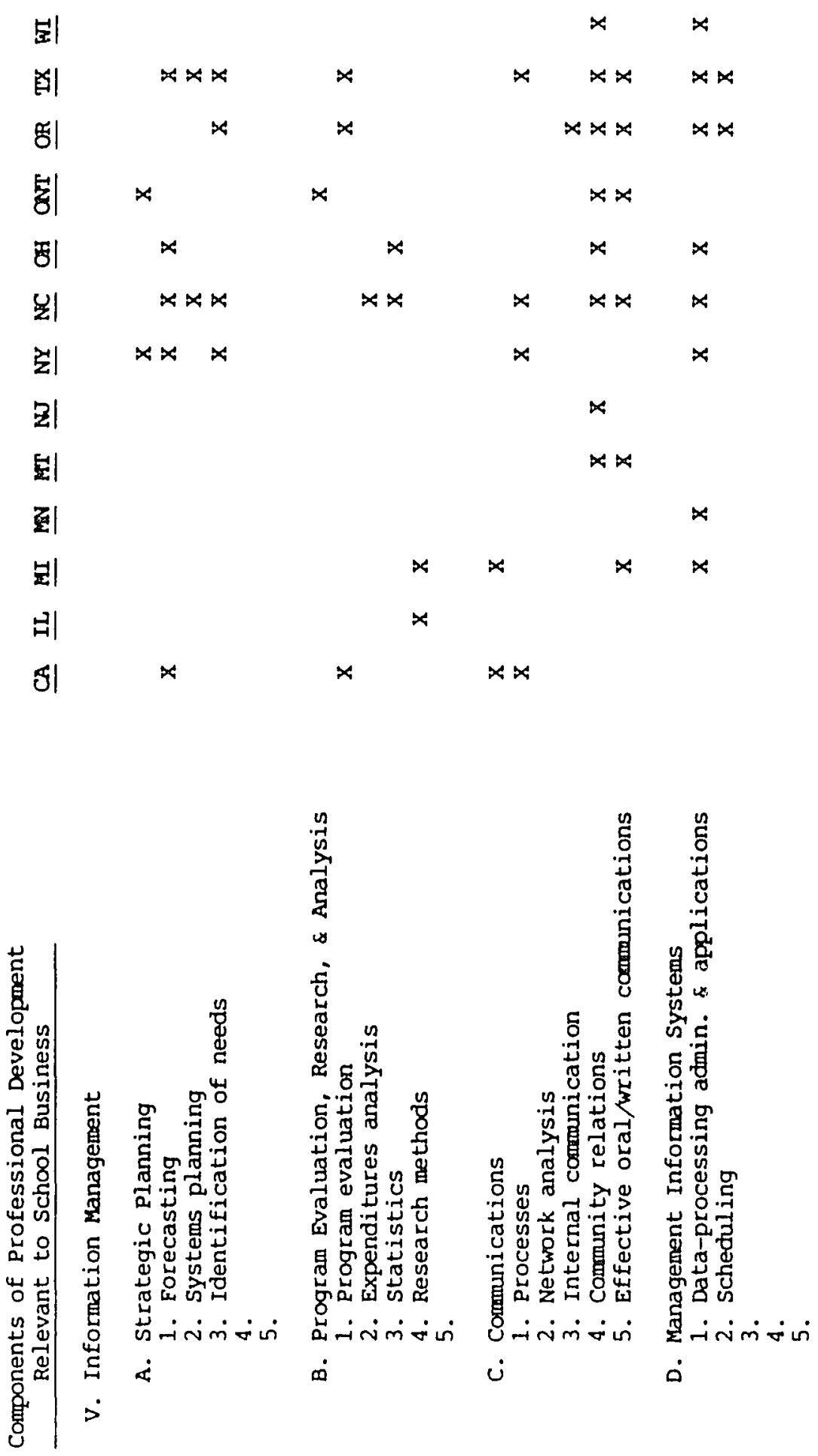

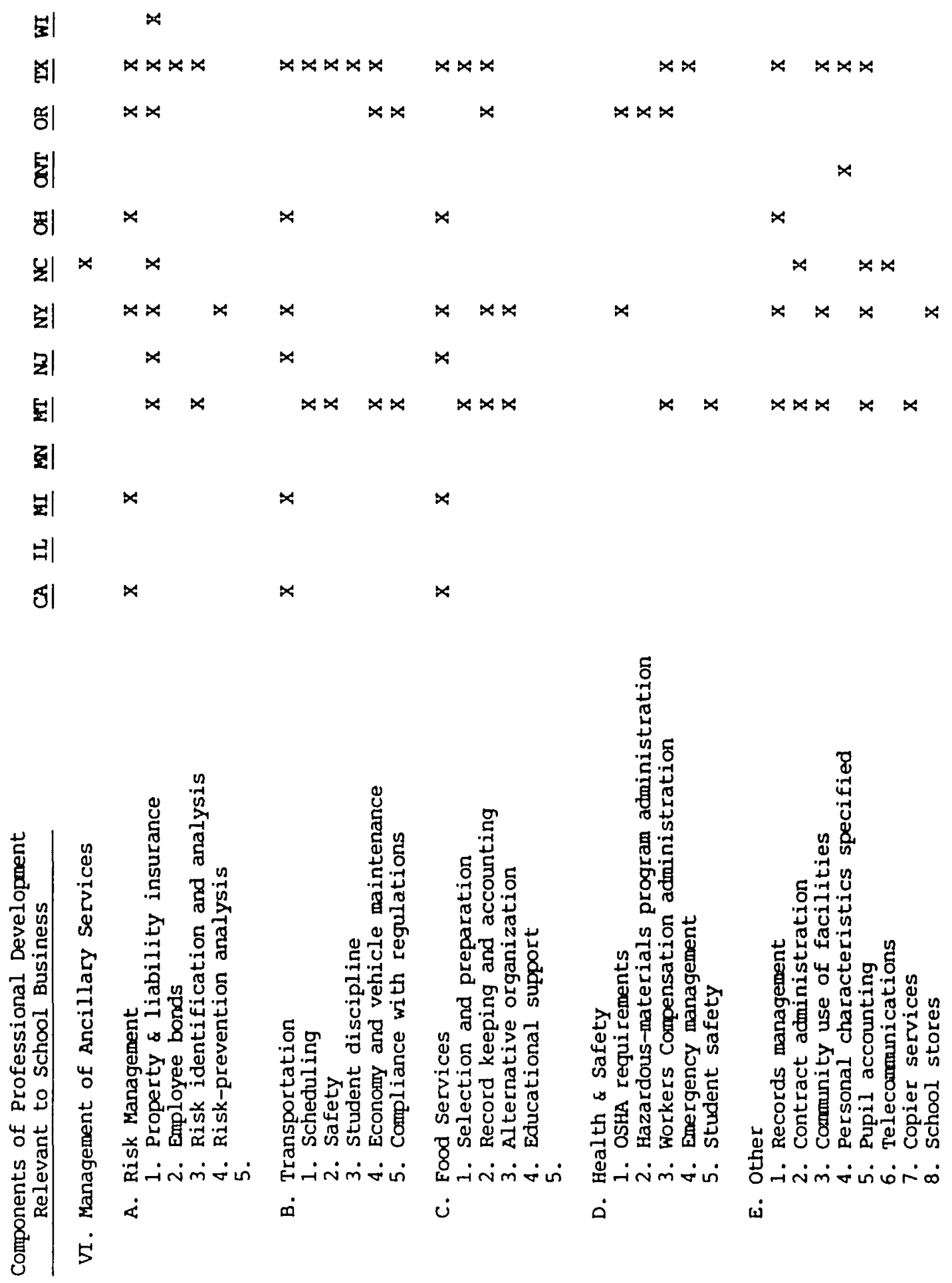
APPENDIX D

\section{MCGUFFEY COMPETENCIES}

COMPARED WITH THE ASBO/DANFORTH MODEL 
MCGUFFEY COMPETENCIES COMPARED WITH THE ASBO/DANFORTH MODEL

ASBO/Danforth

Components of Professional Development

I. The Educational Enterprise
A. Foundations of Teaching and Learning
B. Organization \& Administration
$\mathrm{X}$
C. Public Policy \& Intergovernmental Relations
$\mathrm{x}$
D. Legal Aspects
$\mathrm{x}$

II. Financial Resource Management

A. Principles of School Finance

B. Budgeting \& Financial Planning

C. Accounting, Auditing, \& Financial Reporting

D. Cash Management/Investment \& Debt

$\mathrm{x}$

$\mathrm{X}$

$\mathrm{X}$

III. Human Resource Management
A. Personnel \& Benefits Administration
$\mathrm{x}$
B. Staff Development
$\mathrm{x}$
C. Labor Relations/Collective Bargaining
D. Human Relations

IV. Facility \& Property Management
A. Planning \& Construction
$\mathrm{X}$
B. Maintenance \& Operations
$\mathrm{X}$
C. Purchasing
$\mathrm{X}$
D. Supply \& Equipment Management
$\mathrm{X}$
E. Real-Estate Management 
V. Information Management
A. Strategic Planning
B. Program Evaluation, Research, \& Analysis
C. Communications
D. Management Information Systems

VI. Management of Ancillary Services
A. Risk Management
$\mathrm{X}$
B. Transportation
$\mathrm{x}$
C. Food Services
$\mathrm{X}$
D. Health \& Safety
$\mathrm{x}$
E. Other
$\mathrm{x}$ 
APPENDIX E

SURVEY INSTRUMENT 


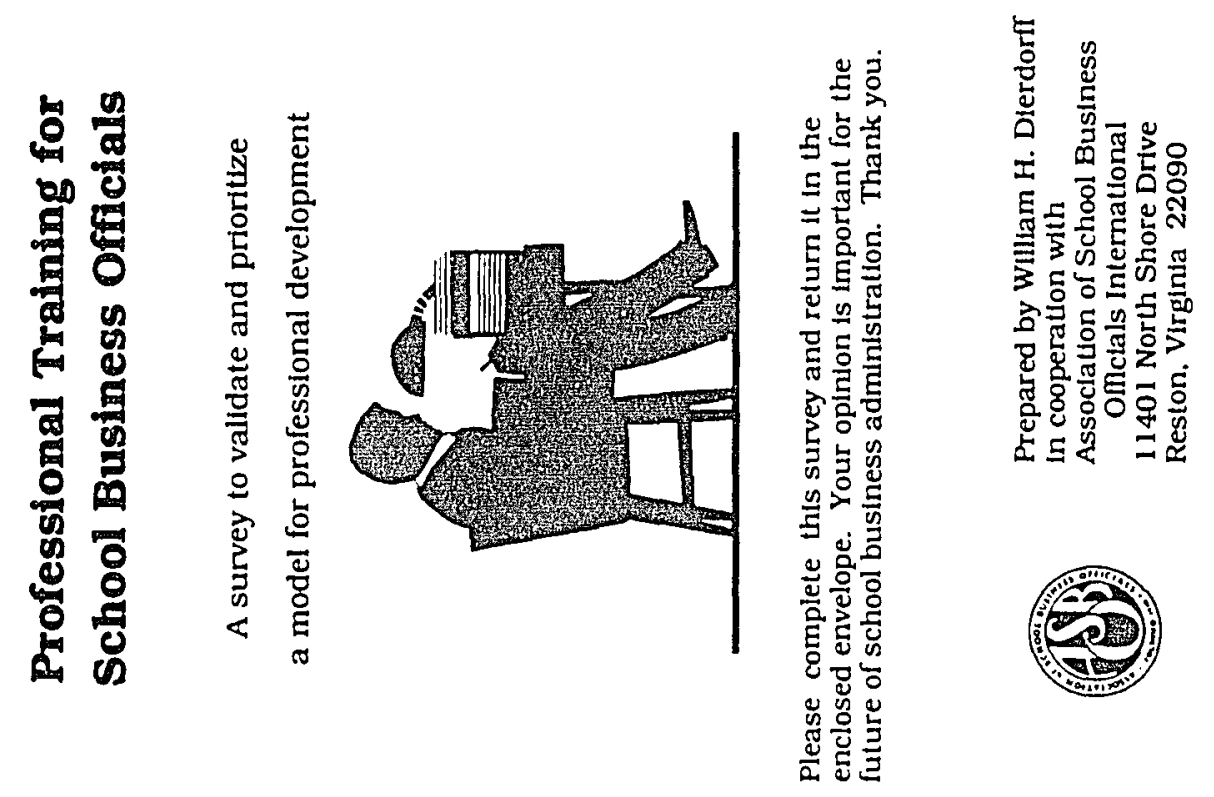



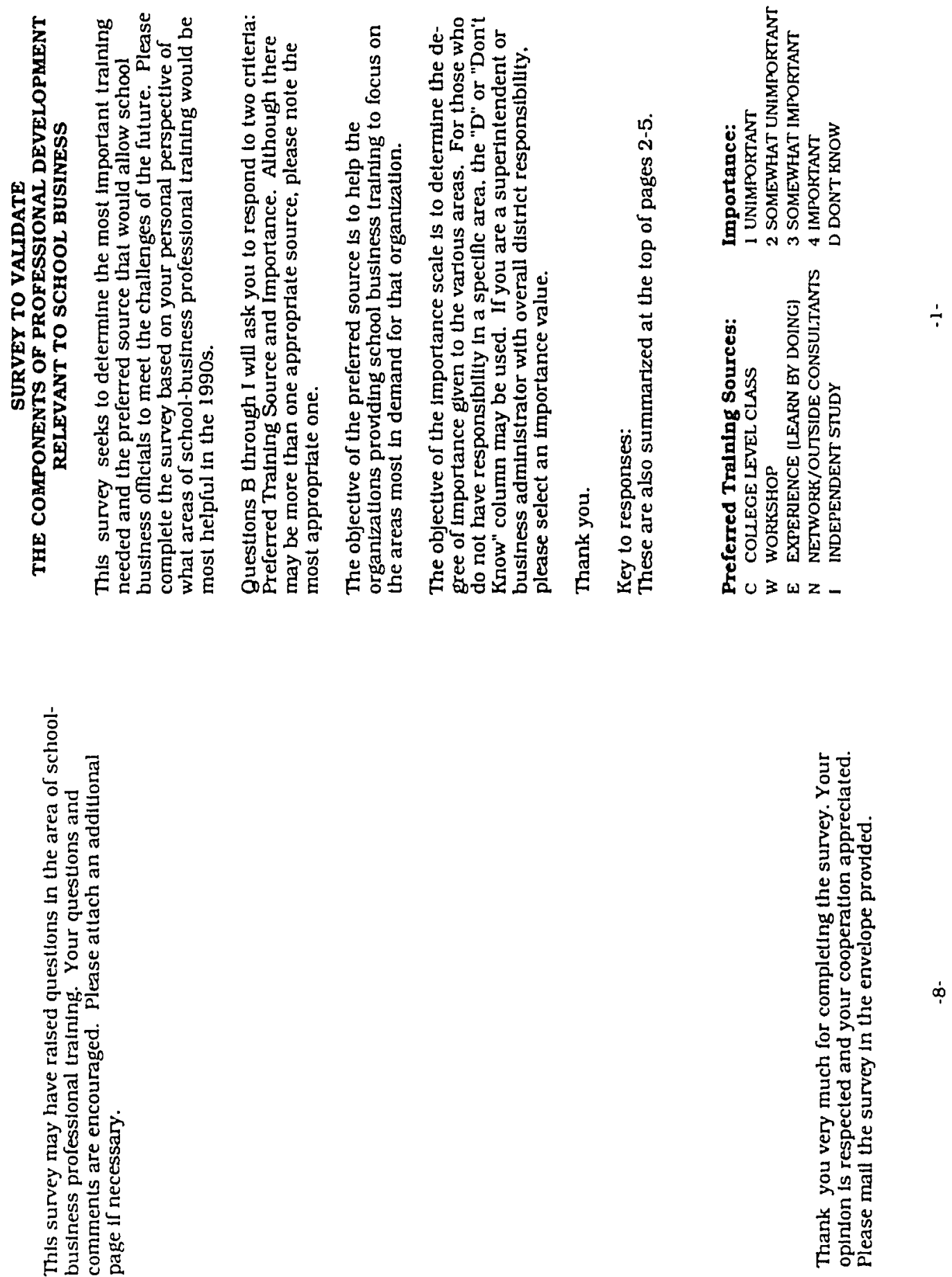

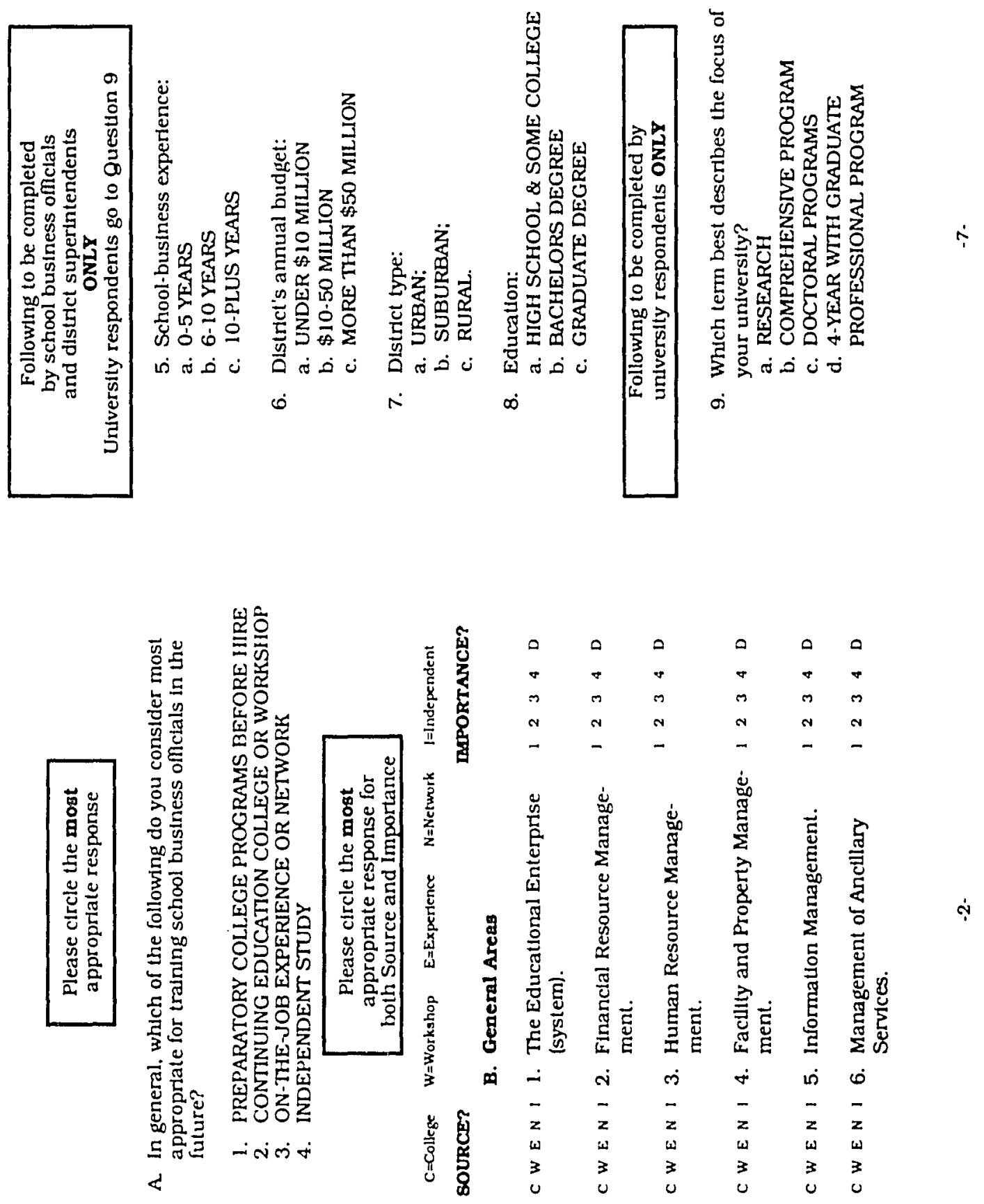

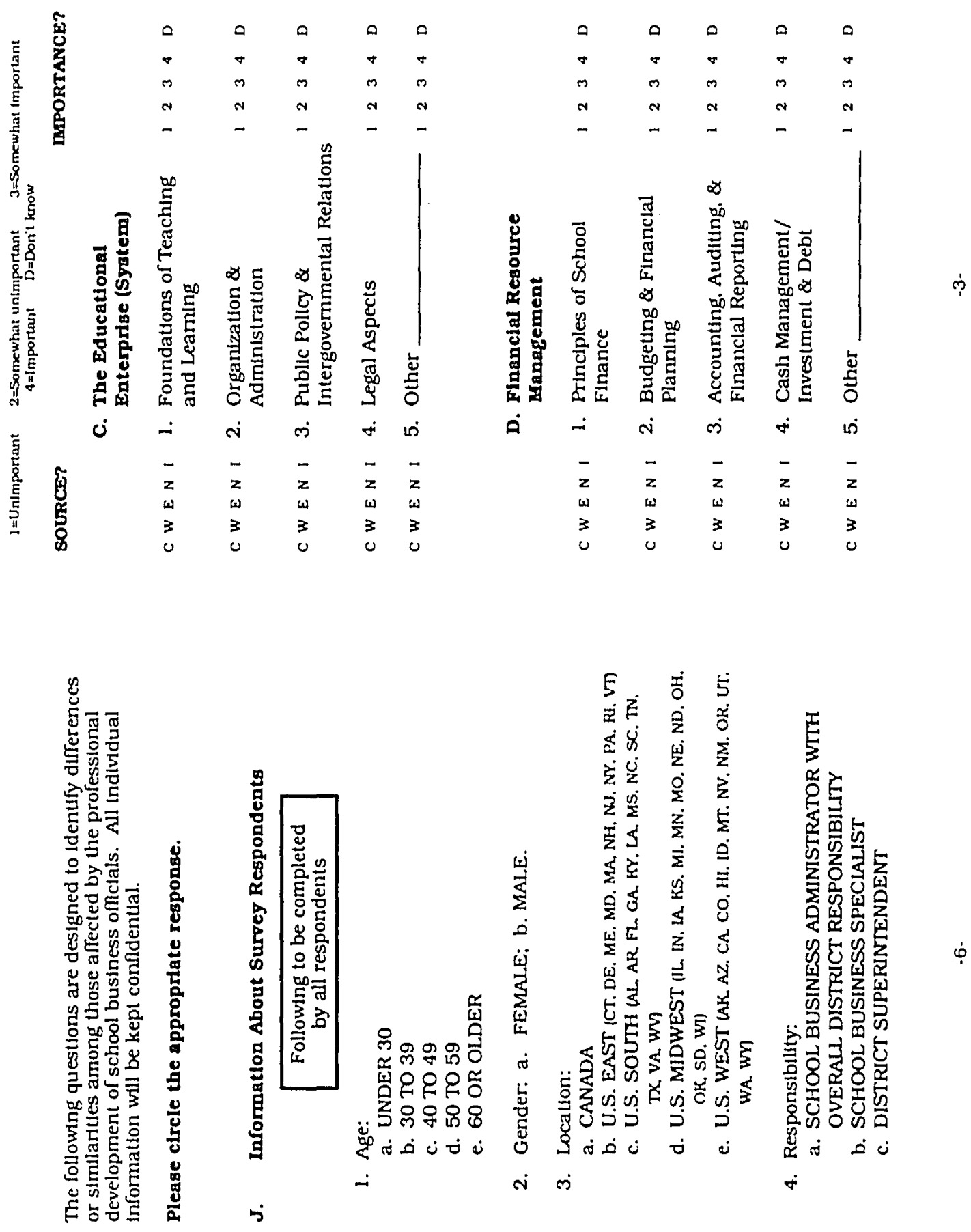

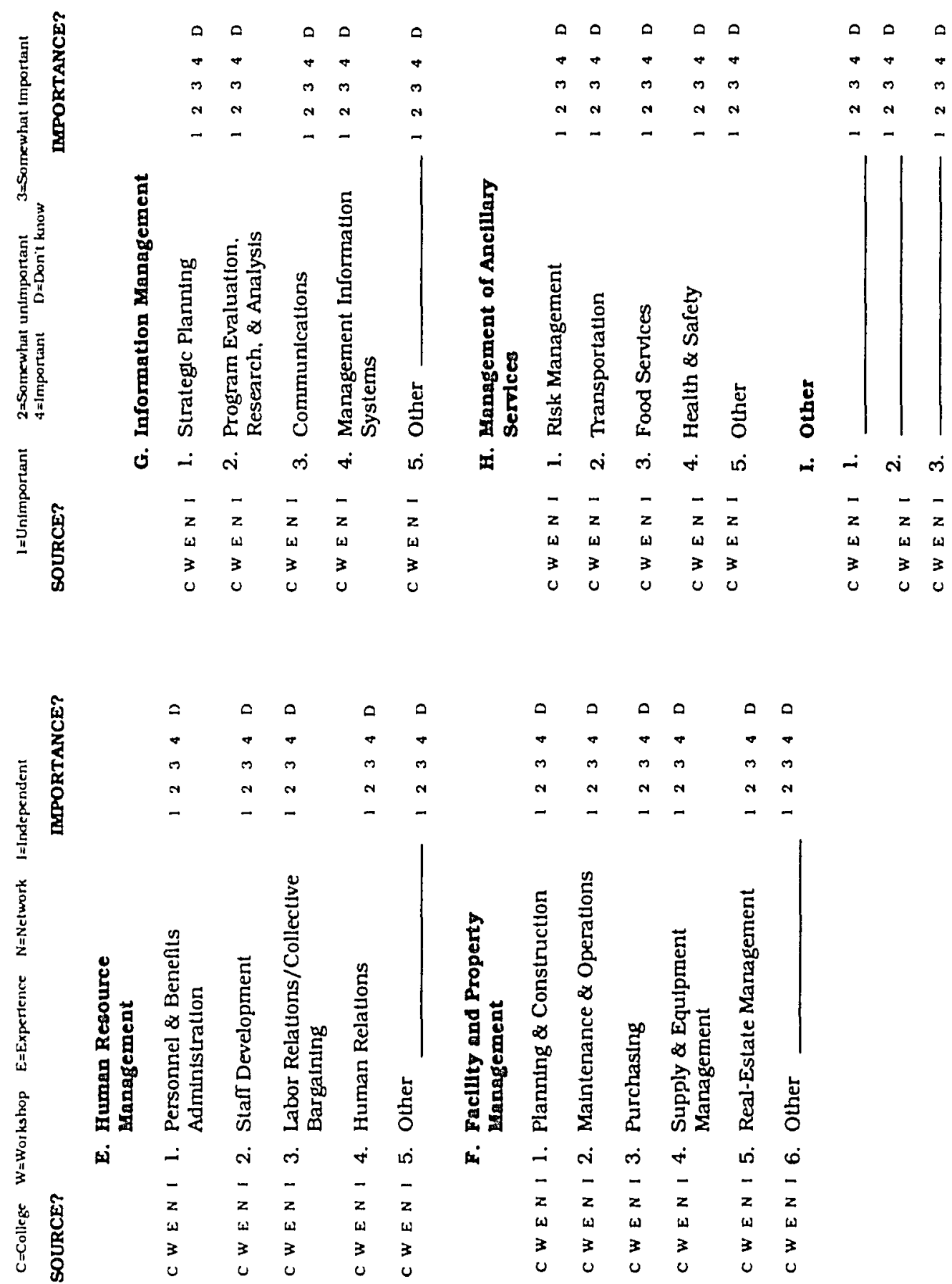
APPENDIX F

\section{SURVEY ENVELOPE}



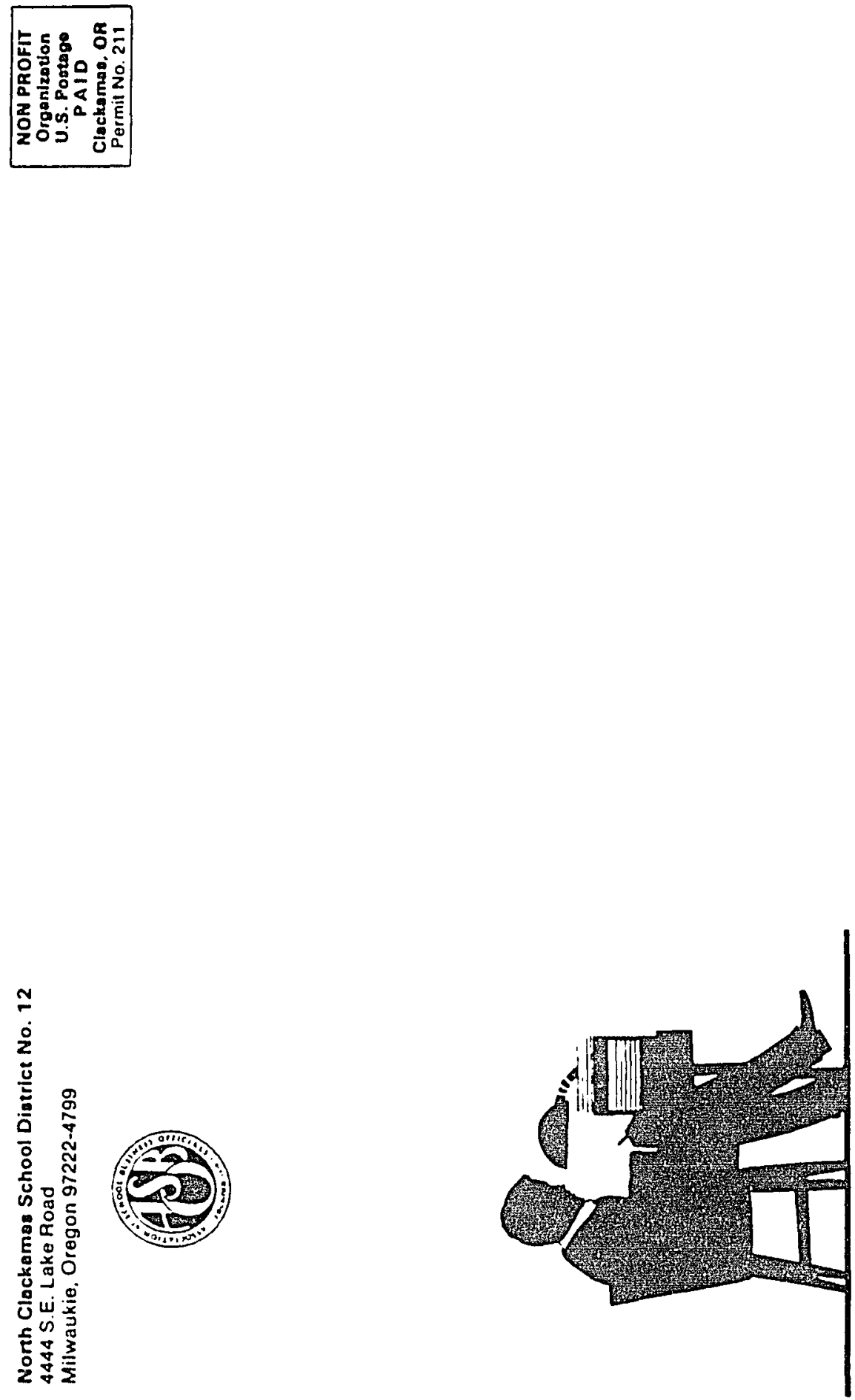
APPENDIX G

\section{LETTERS TO SOLICIT SURVEY RESPONSES}




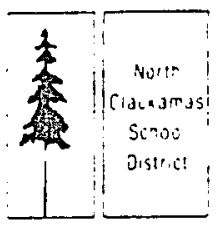

\section{BUSINESS SERVICES \\ 1.144 S E Lake Road. Milwaukte Oregon 97222.4799. (503) 653-3600 \\ BUSINESS MANAGER \\ DIRECTOR OF FISCAL SERVICES \\ Willam H Dierdortt. (503) 653.3604 Diane Larson. (503) 653.3616}

NORTH CLACKAMAS SCHOOL DISTRICT 12

February 28, 1992

Dear School Business Administrator:

Training and continuing education for school business officials are becoming increasingly complex. Because of your position as well as your involvement in professional development, we want to ask your advice and support in helping to improve school-business professional development programs.

A broad perspective on professional needs is essential if school business officials are to be effective in the future. The enclosed survey is based upon a model developed jointly by ASBO International and the Danforth Foundation. Please share your experience and expertise.

Please complete the survey (which takes about five minutes) and return it by March 20, 1992. Survey responses will be confidential; al though you will receive a reminder note, no identification is on the survey documents to designate the recipients. The results will be available through ASBO-I.

Thank you for sharing your valuable time and knowledge to help prepare the school business professionals of the future.

Sincerely,

William H. Dierdorff

Past Chairman

ASBO-I Professional

Development Committee

1js

Enc. 


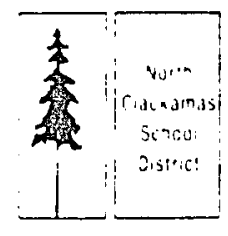

\section{BUSINESS SERVICES \\ L444 SE Lake Road. Milwaukıe. Oregon 97222-4799. 1503)653.3600 \\ BUSINESS MANAGER \\ DIRECTOR OF FISCAL SERVICES \\ Willam H. Dierdortt. (503) $653 \cdot 3604$ \\ Diane Larson $503 i 653.3616$}

NORTH CLACKAMAS SCHOOL DISTRICT 12

February 28, 1992

Dear Superintendent:

Training and continuing education for school business officials are becoming increasingly complex. Because of your position, we want to ask your advice and support in helping to improve school-business professional development programs.

A broad perspective on professional needs is essential if school business officials are to be effective in the future. We need your perspective as a primary recipient of the services of school-business administrators. The enclosed survey is based upon a model developed jointly by ASBO International and the Danforth Foundation. Please share your experience and expertise.

Please complete the survey (which takes about five minutes) and return it by March 20, 1992. Survey responses will be confidential; although you will receive a reminder note, no identification is on the survey documents to designate the recipients. The results will be available through ASBO-I.

Thank you for sharing your valuable time and knowledge to help prepare the school business professionals of the future.

Sincerely,

William H. Dierdorff

Past Chairman

ASBO-I Professional

Development Committee

$1 \mathrm{js}$

Enc. 


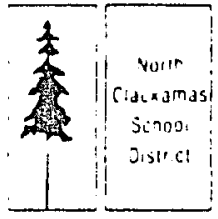

\section{BUSINESS SERVICES \\ 4444 S E. Lake Road. Milwaukı Oregon 97222-4799. (503) $653 \cdot 3600$ \\ BUSINESS MANAGER \\ DIRECTOR OF FISCAL SERVICES \\ William H Dierdort, (503) 653-3604 \\ Diane Larson. $1503,653.3616$}

NORTH CLACKAMAS SCHOOL DISTRICT 12

February 28, 1992

Dear Dean of Educational Administration:

Training and continuing education for school business officials are becoming increasingly complex. Because of your position, we want to ask your advice and support in helping to improve school-business professional development programs.

A broad perspective on professional needs is essential if school business officials are to be effective in the future. We need your perspective as a primary provider of training for school administration. The enclosed survey is based upon a model developed jointly by ASBO International and the Danforth Foundation. Please share your experience and expertise.

Please complete the survey (which takes about five minutes) and return it by March 20, 1992. Survey responses will be confidential; although you will receive a reminder note, no identification is on the survey documents to designate the recipients. The results will be available through ASBO-I.

Thank you for sharing your valuable time and knowledge to help prepare the school business professionals of the future.

Sincerely,

William H. Dierdorff

Past Chairman

ASBO-I Professional

Development Committee

ijs

Enc. 


\section{APPENDIX H}

POSTCARD REMINDER/THANK-YOU 
North Clackamas School District No. 12

4444 S. E. Lake Road

Milwaukie, Oregon 97222-4799
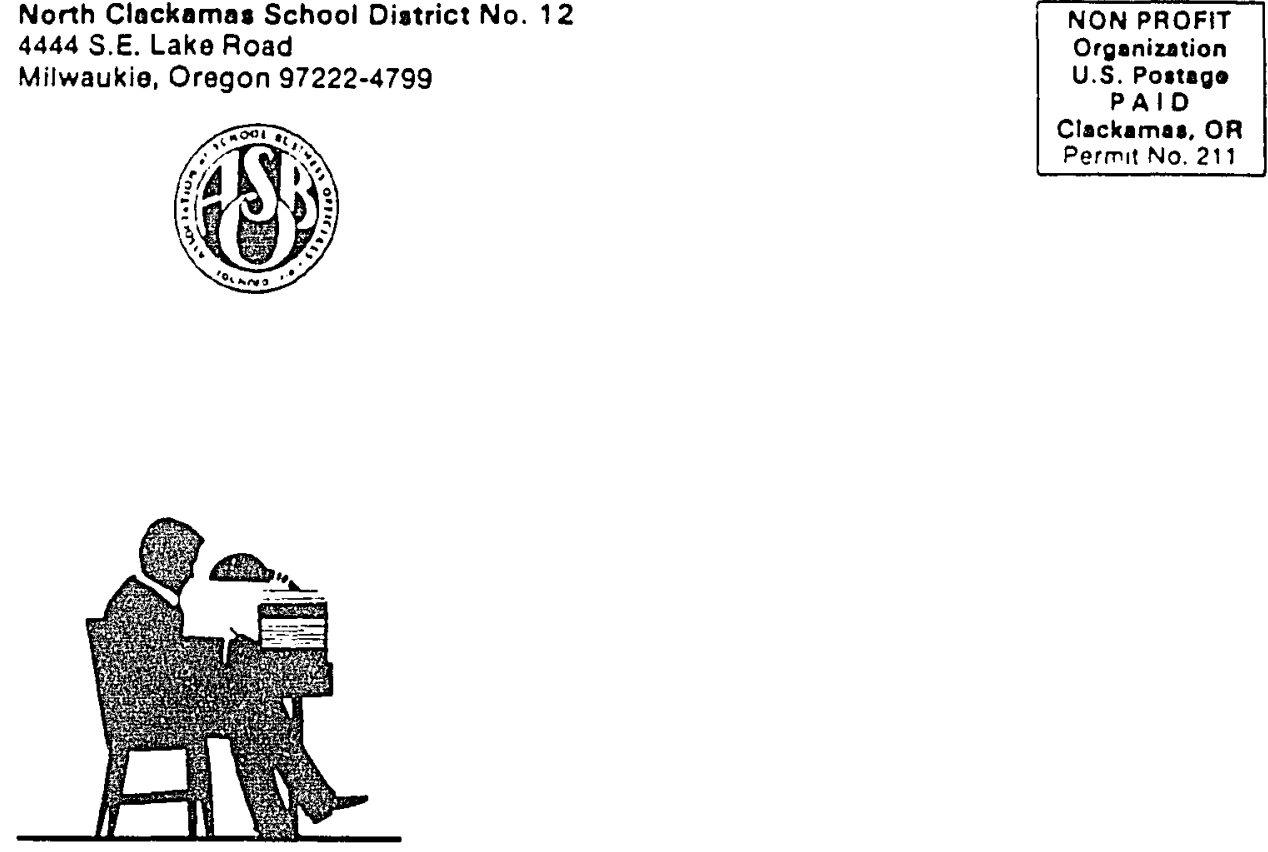

\section{Professional Training for School Business Officials}

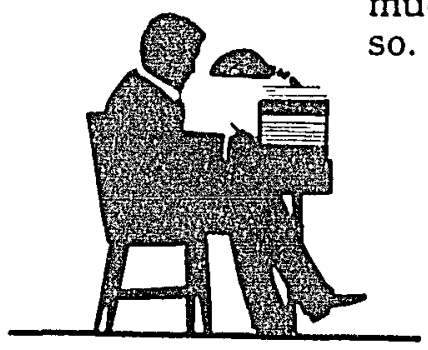

Recently you recelved a survey for school business training. If you have returned it. thank you very much. If not. please take the few minutes to do so.

Your help is appreciated. Thanks!

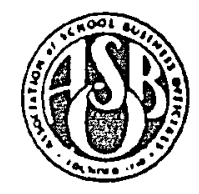


APPENDIX I

RETURN ENVELOPE 

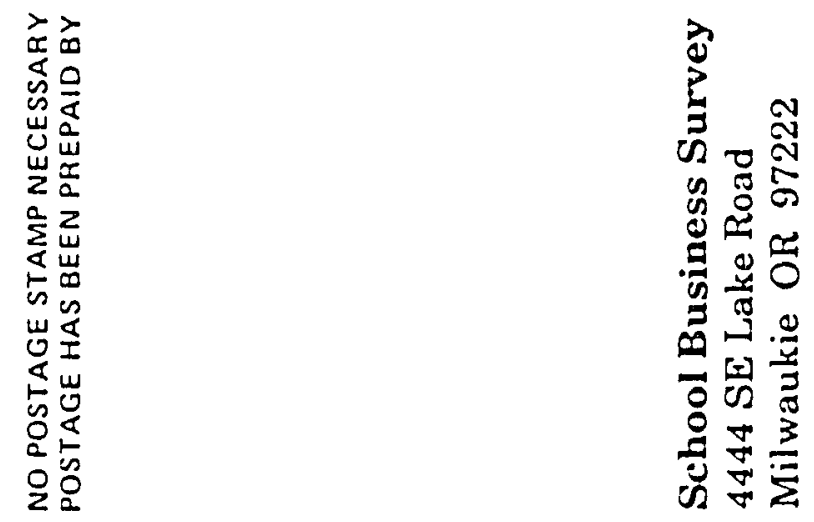
APPENDIX $J$

CODE BOOK FOR VARIABLES

OF PROFESSIONAL DEVELOPMENT

NEEDED FOR SCHOOL BUSINESS OFFICIALS 


\section{CODE BOOK FOR VARIABLES \\ OF PROFESSIONAL DEVELOPMENT \\ NEEDED FOR SCHOOL BUSINESS OFFICIALS}

Variable Name Variable Definition Value

(NOTE: FOR ALL CATEGORIES $\bullet=$ No answer)

SSOURCES

ATRAIN

Appropriate training

$1=$ Prep college

$2=$ Continuing education

$3=$ Experience

$4=$ Independent study

BEDENTS Educational enterprise

$1=$ College

$2=$ Workshop

BFINRESS Financial resource management

$3=$ Experience

$4=$ Network

BHUMRESS Human resource management

$5=$ Independent

BFACPROS Facility and property management

BINFORS Information management

BANCSERS Management of ancillary services

CFOUTLS Foundations of teaching \& learning

CORGADS Organization \& administration

CPUBPOLS Public policy \& intergovernmental relations

CLEGALS Legal Aspects

COTHER

DSCOFINS Principles of school finance

DBUDFINS Budgeting \& financial planning

DACAUDS Accounting, auditing, \& financial reporting 


\begin{tabular}{|c|c|}
\hline Variable Name & Variable Definition \\
\hline DCASHS & Cash management, investment, \& $d$ \\
\hline DOTHERS & \\
\hline EPERBENS & Personnel \& benefits administration \\
\hline ESTAFDS & Staff development \\
\hline ELABORS & Labor relations/collective bargaining \\
\hline EHUMRELS & Human relations \\
\hline EOTHERS & \\
\hline FPLACONS & Planning \& construction \\
\hline FMAINOS & Maintenance \& operations \\
\hline FPURCHS & Purchasing \\
\hline FSUPEQS & Supplies \& equipment management \\
\hline FREALES & Real-estate management \\
\hline FOTHERS & \\
\hline GSTRPLNS & Strategic planning \\
\hline GEVALRES & $\begin{array}{l}\text { Program evaluation, research, and } \\
\text { analysis }\end{array}$ \\
\hline GCOMMS & Communications \\
\hline GMISS & Management information systems \\
\hline GOTHERS & \\
\hline HRISKMS & Risk management \\
\hline HTRANSPS & Transportation \\
\hline HFOODSRS & Food services \\
\hline HHEALTHS & Health \& safety \\
\hline
\end{tabular}

Value 


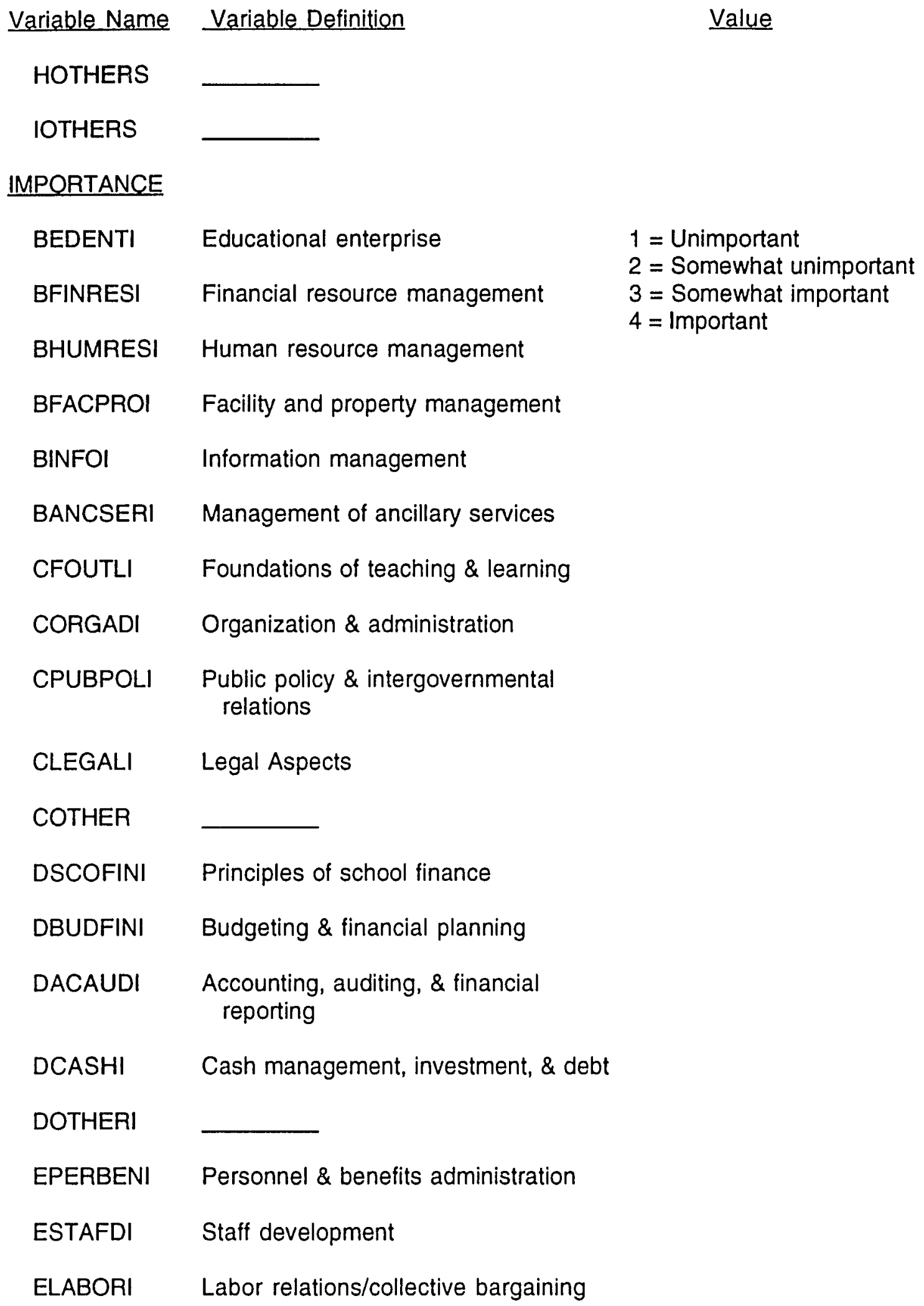




\begin{tabular}{ll} 
Variable Name & \multicolumn{2}{c}{ Variable Definition } \\
EHUMRELI & Human relations \\
EOTHERI & \\
FPLACONI & Planning \& construction \\
FMAINOI & Maintenance \& operations \\
FPURCHI & Purchasing \\
FSUPEQI & Supplies \& equipment management \\
FREALEI & Real-estate management \\
FOTHERI & \\
GSTRPLNI & Strategic planning \\
GEVALREI & Program evaluation, research, and \\
analysis
\end{tabular}

Value 
Variable Name Variable Definition

Value

\section{DEMOGRAPHICS}

\begin{tabular}{|c|c|c|}
\hline JAGE & Age & $\begin{array}{l}1=\text { Under } 30 \\
2=30-39 \\
3=40-49 \\
4=50-59 \\
5=60 \& \text { older }\end{array}$ \\
\hline JGENDER & Gender & $\begin{array}{l}1=\text { Female } \\
2=\text { Male }\end{array}$ \\
\hline JLOCAT & Location & $\begin{array}{l}1=\text { Canada } \\
2=\text { U.S. east } \\
3=\text { U.S. south } \\
4=\text { U.S. midwest } \\
5=\text { U.S. west }\end{array}$ \\
\hline JRESP & Responsibility & $\begin{array}{l}1 \text { = School business } \\
\text { administration } \\
2=\text { School business } \\
\text { specialist } \\
3 \text { = Superintendent }\end{array}$ \\
\hline JEXP & School business experience & $\begin{array}{l}1=0-5 \text { years } \\
2=6-10 \text { years } \\
3=10 \text {-plus years }\end{array}$ \\
\hline JBUDG & District's annual budget & $\begin{array}{l}1=\text { Under } \$ 10 \text { million } \\
2=\$ 10-50 \text { million } \\
3=\text { Over } \$ 50 \text { million }\end{array}$ \\
\hline JTYPE & District type & $\begin{array}{l}1=\text { Urban } \\
2=\text { Suburban } \\
3=\text { Rural }\end{array}$ \\
\hline JEDUC & Education & $\begin{array}{l}1=\text { High school } \\
2=\text { Bachelor's degree } \\
3=\text { Graduate degree }\end{array}$ \\
\hline JUNIV & University type & $\begin{array}{l}1=\text { Research } \\
2=\text { Comprehensive } \\
3=\text { Doctoral } \\
4=4 \text {-year } \text { w/grad. }\end{array}$ \\
\hline
\end{tabular}


APPENDIX K

SUMMARY OF COMMENTS 
SUMMARY OF COMMENTS

The following comments were written on the surveys returned and are listed in the order received.

1. School business officials need to be utilized more by the district top management.

2. Our program at the university is for principals only; no school business training is provided. (Survey not completed.)

3. We do not prepare administrators.

4. College training is the cornerstone of professional preparation; e.g. accounting, law, architecture, engineering, computer science, and others. Workshops, networking, etc., help keep you up to date and develops contacts.

5. Nature of funding affects needs. For example, if state or province dictates or handles bonds, local agency officials would not need to be trained in this area.

6. Iowa has instituted a school business management academy.

7. Be a team player; relate to your trustees. Need professional designation and added courses and experience in educational administration.

8. Should have the choice to mark both college (C) and experience $(E)$.

9. Should have had a "very important" category.

10. Could distinguish college for officials, informal or workshop for clerks.

11. College classes aren't enough. More business should be taught to school administration.

12. Business of education should be managed by other professionals, not building principals and superintendents.

13. Extremely important for school business manager to have a background in education (teacher and/or principal) so they understand how a school system operates. knowledge of fund-raising and foundations is a definite plus, along with investments and cash flow. Ability to deal with and involve people is very important. 
14. The questionnaire is irrelevant. All areas are needed and all training methods are needed. To de-emphasize any issue or delivery system short-changes public education.

15. Confusing. (Did not complete.)

16. Business managers need to be experts in their areas and understand that the mission is to support the education of students.

17. Selecting a single source is difficult; prefer multiple choice.

18. School business officials should be trained in schools of business, supplemented by education-administration classes frorn the school of education.

19. Difficult to select more important categories; all are needed and critical.

20. A college background is needed, and job experience complements that.

21. Difficult to select most important source. No method alone is effective--need training and experience.

22. General knowledge and "how to" find answers should be taught in college. Specific job or state needs should be by workshop.

23. After eight years, I haven't found a college-level course directly related to school finance. It would be nice to have.

24. Need a balance of academic training and experience. Must know theory and how to locate resource material. Application can be learned only through experience. Integrity is the highest quality, and it can't be taught or gained through experience. 
APPENDIX L

OTHER AREAS SUGGESTED

FOR PROFESSIONAL DEVELOPMENT 
A. Suggestions listed in order received

\begin{tabular}{|c|c|c|}
\hline $\begin{array}{l}\text { Response } \\
\text { Number }\end{array}$ & $\begin{array}{l}\text { Survey } \\
\text { Number }\end{array}$ & Suggested Area \\
\hline 1. & $\begin{array}{l}\text { C5 } \\
\text { E5 } \\
\text { E6 } \\
\text { G5 }\end{array}$ & $\begin{array}{l}\text { Education goals } \\
\text { Learning process } \\
\text { Management of instructional materials } \\
\text { Instructional design }\end{array}$ \\
\hline 2. & $\begin{array}{l}\text { D5 } \\
\text { I1 } \\
\text { I2 }\end{array}$ & $\begin{array}{l}\text { Cost-benefit analysis of direct } \\
\text { instructional programs } \\
\text { Ethics and survival in school business } \\
\text { Politics of school finance }\end{array}$ \\
\hline 3. & & GASB pronouncements with examples \\
\hline 4. & & $\begin{array}{l}\text { Require more business courses of school } \\
\text { administrators }\end{array}$ \\
\hline 5. & I1 & $\begin{array}{l}\text { Current state law } \\
\text { Negotiations, in general }\end{array}$ \\
\hline 6. & $\begin{array}{l}\text { C5 } \\
\text { D5 }\end{array}$ & $\begin{array}{l}\text { Politics of educaton } \\
\text { Funding methods }\end{array}$ \\
\hline 7. & H5 & $\begin{array}{l}\text { Investments and money management } \\
\text { (already D4) }\end{array}$ \\
\hline 8. & $\begin{array}{l}\text { E5 } \\
\text { I1 }\end{array}$ & $\begin{array}{l}\text { Principles of supervision } \\
\text { Housekeeping }\end{array}$ \\
\hline 9. & C5 & Ethics \\
\hline 10. & $\begin{array}{l}\text { C5 } \\
\text { D5 } \\
\text { E5 } \\
\text { F6 } \\
\text { G5 } \\
\text { H5 }\end{array}$ & $\begin{array}{l}\text { Risk management (already H1) } \\
\text { Payroll } \\
\text { Payroll } \\
\text { Risk management } \\
\text { Administration, and personnel management } \\
\quad \text { (already E1) } \\
\text { Warehousing/purchasing (already F3, F4) }\end{array}$ \\
\hline 11. & H5 & Construction \\
\hline 12 . & $\begin{array}{l}\text { I1 } \\
\text { E5 }\end{array}$ & $\begin{array}{l}\text { Time management } \\
\text { Conflict resolution }\end{array}$ \\
\hline
\end{tabular}




\begin{tabular}{|c|c|c|}
\hline 13. & $\begin{array}{l}\text { C5 } \\
\text { D5 }\end{array}$ & $\begin{array}{l}\text { State politics } \\
\text { State and federal policies }\end{array}$ \\
\hline 14. & C5 & Risk management (already H1) \\
\hline 15. & II & P.C. operations \\
\hline 16. & II & All of the above \\
\hline 17. & $\begin{array}{l}\text { C5 } \\
\text { D5 }\end{array}$ & $\begin{array}{l}\text { Data management } \\
\text { office politics }\end{array}$ \\
\hline 18. & $\begin{array}{l}\text { G5 } \\
\text { I1 } \\
\text { I5 }\end{array}$ & $\begin{array}{l}\text { Letter writing } \\
\text { School-community relations } \\
\text { Selection of professional services (CPA, } \\
\text { attorney, architect) }\end{array}$ \\
\hline 19. & $\begin{array}{l}\text { I1 } \\
\text { I2 }\end{array}$ & $\begin{array}{l}\text { Political science } \\
\text { Public-safety awareness }\end{array}$ \\
\hline 20. & I1 & Self-fund insurance \\
\hline 21. & $\mathrm{C5}$ & Government accounting \\
\hline
\end{tabular}

B. Summary of additional suggested topics that do not fit directly under the categories of the ASBO/Danforth model

\section{Topic}

Comment Frequency

Ethics

Politics

2

General negotiations skills

Alternative funding methods

General management

Selecting providers of professional

services 
APPENDIX M

DESCRIPTION STATISTICS 


\begin{tabular}{|c|c|c|c|c|}
\hline \multirow{2}{*}{ COUNT } & \multicolumn{2}{|l|}{ CUM } & CUM & \multirow[b]{2}{*}{ ATRAIN } \\
\hline & COUNT & PCT & PCT & \\
\hline 108 & 108 & 43.0 & 43.0 & 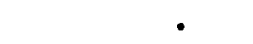 \\
\hline 60 & 168 & 23.9 & 66.9 & 1.0 \\
\hline 51 & 219 & 20.3 & 87.3 & \\
\hline 32 & 251 & 12.7 & 100.0 & 3.0 \\
\hline & CUM & & CUM & \\
\hline OUNT & COUNT & PCT & PCT & BEDENTS \\
\hline 7 & 7 & 2.8 & 2.8 & - \\
\hline 149 & 156 & 59.4 & 62.2 & 1.0 \\
\hline 43 & 199 & 17.1 & 79.3 & 2.0 \\
\hline 47 & 246 & 18.7 & 98.0 & 3.0 \\
\hline 2 & 248 & .8 & 98.8 & 0 \\
\hline 3 & 251 & 1.2 & 100.0 & r \\
\hline
\end{tabular}

\begin{tabular}{rrrrr}
\multicolumn{7}{c}{ CUM } & \multicolumn{3}{c}{ CUM } \\
COUNT & COUNT & PCT & PCT & BFINRESS \\
5 & 5 & 2.0 & 2.0 &. \\
146 & 151 & 58.2 & 60.2 & 1.000 \\
62 & 213 & 24.7 & 84.9 & 2.000 \\
32 & 245 & 12.7 & 97.6 & 3.000 \\
6 & 251 & 2.4 & 100.0 & 4.000
\end{tabular}

\begin{tabular}{|c|c|c|c|c|}
\hline \multirow[b]{2}{*}{ corrum } & CUM & & CUM & \\
\hline & COUNT & PCT & PCT & BHUMRESS \\
\hline & 4 & 1.6 & 1.6 & • \\
\hline 108 & 112 & 43.0 & 44.6 & 1.000 \\
\hline 84 & 196 & 33.5 & 78.1 & 2.000 \\
\hline 45 & 241 & 17.9 & 96.0 & 3.000 \\
\hline 9 & 250 & 3.6 & 99.6 & 4.000 \\
\hline 1 & 251 & 4 & 100.0 & 000 \\
\hline
\end{tabular}

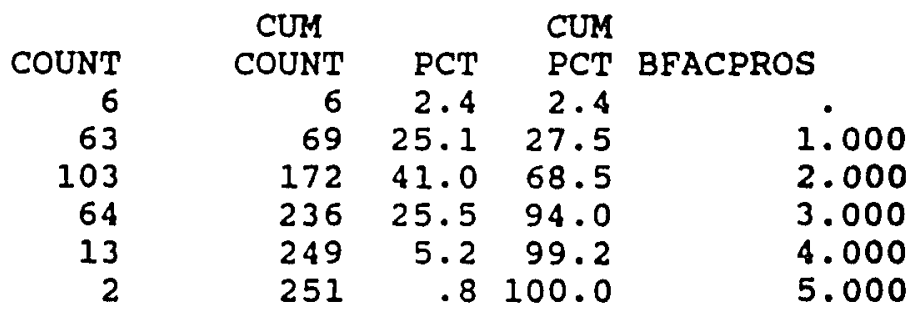

\begin{tabular}{rrrrc}
\multicolumn{1}{c}{ CUM } & & CUM & \\
COUNT & COUNT & PCT & PCT & BINFORS \\
5 & 5 & 2.0 & 2.0 &. \\
111 & 116 & 44.2 & 46.2 & 1.000 \\
78 & 194 & 31.1 & 77.3 & 2.000 \\
35 & 229 & 13.9 & 91.2 & 3.000 \\
17 & 246 & 6.8 & 98.0 & 4.000 \\
5 & 251 & 2.0 & 100.0 & 5.000
\end{tabular}




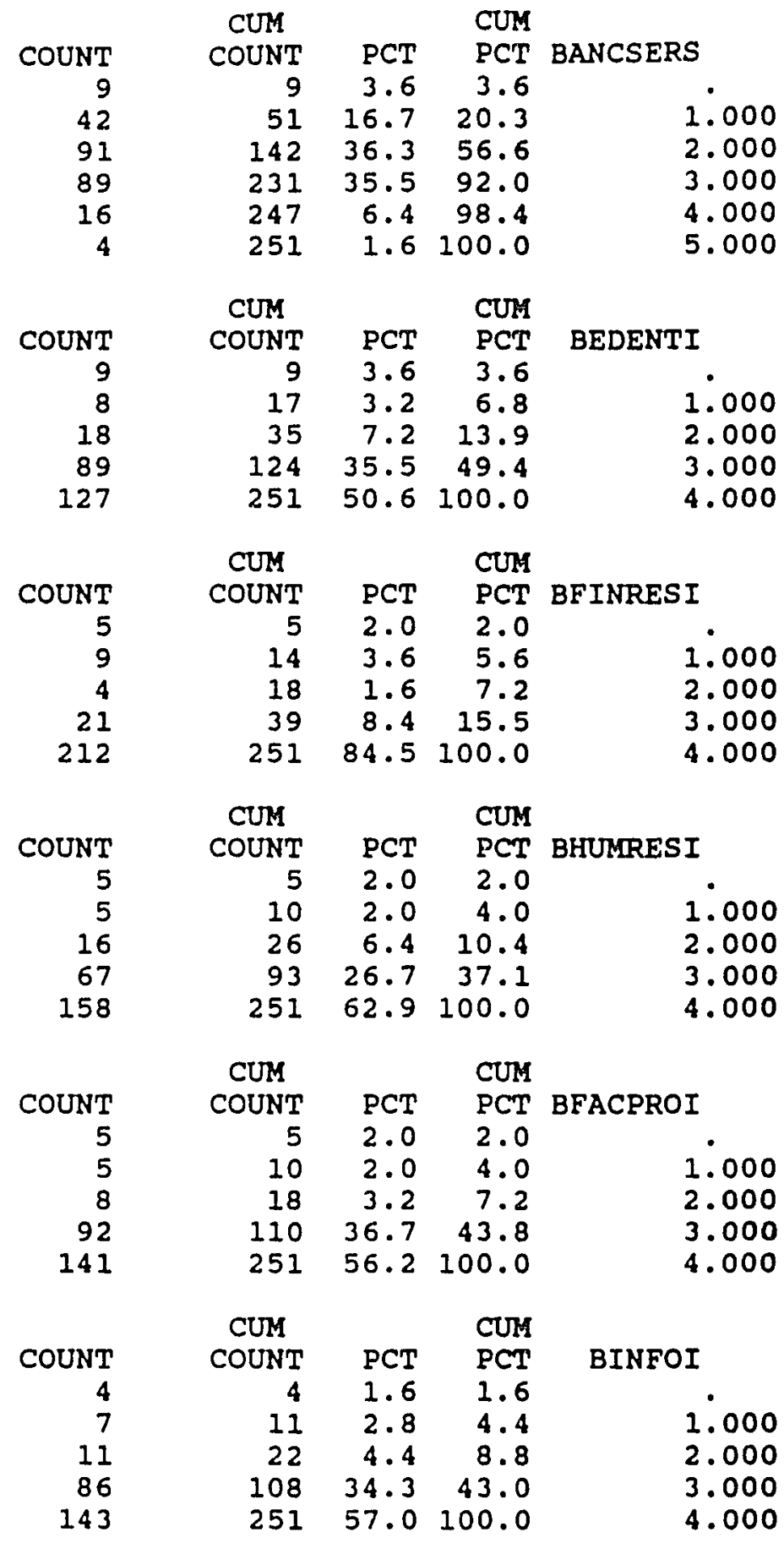




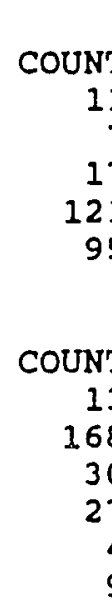

\begin{tabular}{rrrr} 
CUM & & CUM & \\
COUNT & PCT & PCT & BANCSERI \\
11 & 4.4 & 4.4 & 1 \\
18 & 2.8 & 7.2 & 1.000 \\
35 & 6.8 & 13.9 & 2.000 \\
156 & 48.2 & 62.2 & 3.000 \\
251 & 37.8 & 100.0 & 4.000 \\
CUM & & CUM & \\
COUNT & PCT & PCT & \multicolumn{1}{l}{ CFOUTLS } \\
13 & 5.2 & 5.2 & \\
181 & 66.9 & 72.1 & 1.000 \\
211 & 12.0 & 84.1 & 2.000 \\
238 & 10.8 & 94.8 & 3.000 \\
242 & 1.6 & 96.4 & 4.000 \\
251 & 3.6 & 100.0 & 5.000 \\
& & & \\
CUM & & CUM & \\
COUNT & PCT & PCT & CORGADS \\
7 & 2.8 & 2.8 &. \\
173 & 66.1 & 68.9 & 1.000 \\
211 & 15.1 & 84.1 & 2.000 \\
246 & 13.9 & 98.0 & 3.000 \\
250 & 1.6 & 99.6 & 4.000 \\
251 & .4 & 100.0 & 5.000
\end{tabular}

\begin{tabular}{rrrrr}
\multicolumn{1}{c}{ CUM } & & CUM & \\
COUNT & COUNT & PCT & PCT & CPUBPOLS \\
5 & 5 & 2.0 & 2.0 &. \\
108 & 113 & 43.0 & 45.0 & 1.000 \\
81 & 194 & 32.3 & 77.3 & 2.000 \\
41 & 235 & 16.3 & 93.6 & 3.000 \\
14 & 249 & 5.6 & 99.2 & 4.000 \\
2 & 251 & .8 & 100.0 & 5.000
\end{tabular}

\begin{tabular}{rrrrr}
\multicolumn{7}{c}{ CUM } & & CUM & \\
COUNT & COUNT & PCT & PCT & CLEGALS \\
5 & 5 & 2.0 & 2.0 & .0 \\
111 & 116 & 44.2 & 46.2 & 1.000 \\
100 & 216 & 39.8 & 86.1 & 2.000 \\
18 & 234 & 7.2 & 93.2 & 3.000 \\
15 & 249 & 6.0 & 99.2 & 4.000 \\
2 & 251 & .8 & 100.0 & 5.000 \\
& CUM & & CUM & \\
COUNT & COUNT & PCT & PCT & COTHERS \\
238 & 238 & 94.8 & 94.8 &. \\
6 & 244 & 2.4 & 97.2 & 1.000 \\
3 & 247 & 1.2 & 98.4 & 2.000 \\
3 & 250 & 1.2 & 99.6 & 3.000 \\
1 & 251 & .4 & 100.0 & 5.000
\end{tabular}




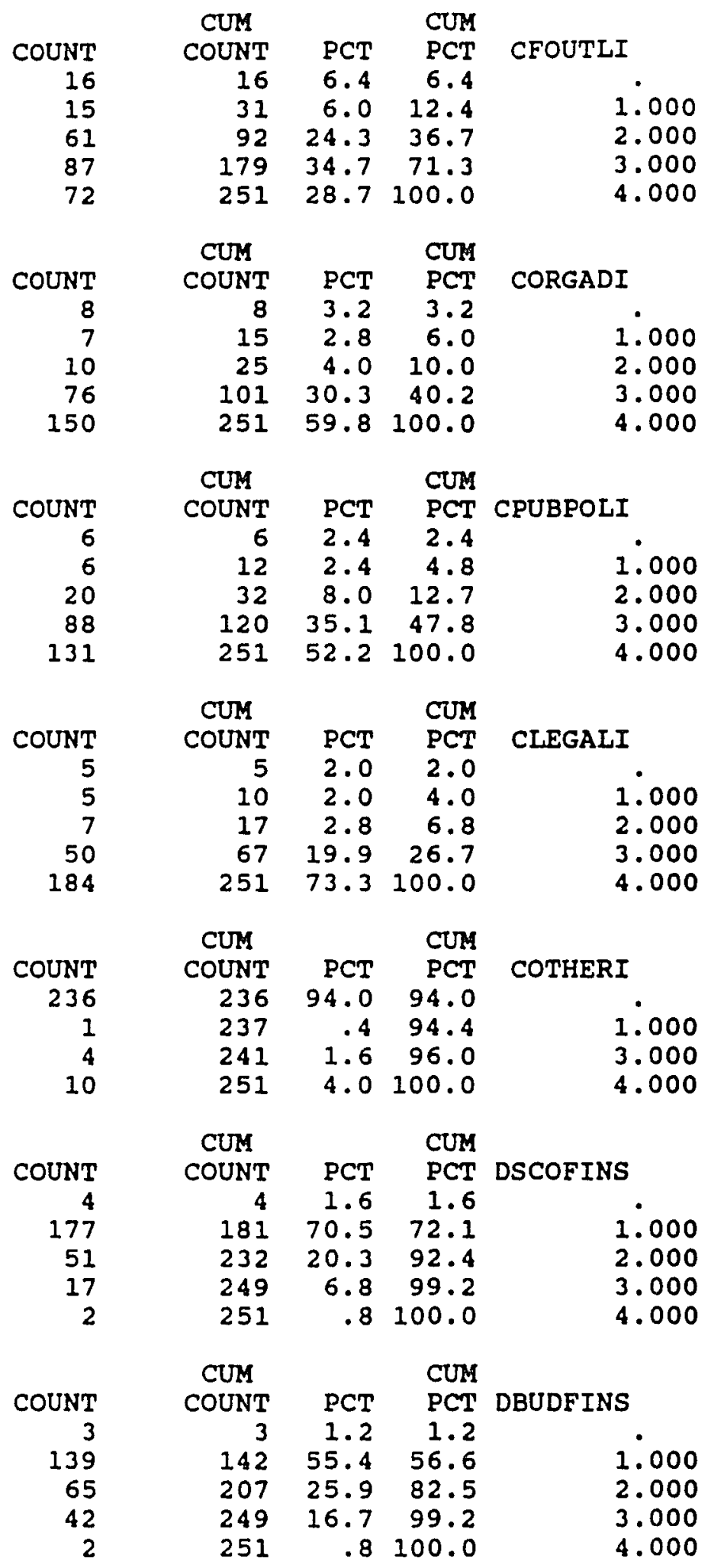




\begin{tabular}{|c|c|c|c|c|}
\hline & CUM & & CUM & \\
\hline COUNT & COUNT & PCT & PCT & DACAUDS \\
\hline $\begin{array}{r}3 \\
178\end{array}$ & $\begin{array}{r}3 \\
181\end{array}$ & 1.2 & $\begin{array}{r}1.2 \\
72.1\end{array}$ & 1.000 \\
\hline $\begin{array}{r}178 \\
53\end{array}$ & $\begin{array}{l}181 \\
234\end{array}$ & $\begin{array}{l}70.9 \\
21.1\end{array}$ & 93.1 & 2.000 \\
\hline 15 & 249 & 6.0 & 99.2 & 3.000 \\
\hline \multirow[t]{2}{*}{2} & 251 & .8 & 100.0 & 4.000 \\
\hline & CUM & & CUN & \multirow[b]{2}{*}{ DCASHS } \\
\hline COUNT & COUNT & PCT & PCT & \\
\hline 7 & 7 & 2.8 & 2.8 & $\theta$ \\
\hline 89 & 96 & 35.5 & 38.2 & 1.000 \\
\hline 112 & 208 & 44.6 & 82.9 & 2.000 \\
\hline 36 & 244 & 14.3 & 97.2 & 3.000 \\
\hline 6 & 250 & 2.4 & 99.6 & 4.000 \\
\hline \multirow[t]{2}{*}{1} & 251 & .4 & 100.0 & 5.000 \\
\hline & CUM & & CUM & \multirow[b]{2}{*}{ DOTHERS } \\
\hline COUNT & COUNT & PCT & PCT & \\
\hline 243 & 243 & 96.8 & 96.8 & - \\
\hline 1 & 244 & .4 & 97.2 & 1.000 \\
\hline 4 & 248 & 1.6 & 98.8 & 2.000 \\
\hline 2 & 250 & .8 & 99.6 & 3.000 \\
\hline \multirow[t]{2}{*}{1} & 251 & .4 & 100.0 & 5.000 \\
\hline & CUM & & CUM & \\
\hline COUNT & COUNT & PCT & PCT & DSCOFINI \\
\hline 5 & 5 & 2.0 & 2.0 & \\
\hline 9 & 14 & 3.6 & 5.6 & 1.000 \\
\hline 2 & 16 & .8 & 6.4 & 2.000 \\
\hline 36 & 52 & 14.3 & 20.7 & 3.000 \\
\hline \multirow[t]{2}{*}{199} & 251 & 79.3 & 100.0 & 4.000 \\
\hline & CUM & & CUM & \\
\hline COUNT & COUNT & PCT & PCT & DBUDFINI \\
\hline 2 & 2 & .8 & .8 & - \\
\hline 10 & 12 & 4.0 & 4.8 & 1.000 \\
\hline 1 & 13 & .4 & 5.2 & 2.000 \\
\hline 10 & 23 & 4.0 & 9.2 & 3.000 \\
\hline \multirow{2}{*}{228} & 251 & 90.8 & 100.0 & 4.000 \\
\hline & CUM & & CUM & \multirow[b]{2}{*}{ DACAUDI } \\
\hline COUNT & COUNT & PCT & PCT & \\
\hline 2 & 2 & .8 & .8 & - \\
\hline 10 & 12 & 4.0 & 4.8 & 1.000 \\
\hline 3 & 15 & 1.2 & 6.0 & 2.000 \\
\hline 32 & 47 & 12.7 & 18.7 & 3.000 \\
\hline 204 & 251 & 81.3 & 100.0 & 4.000 \\
\hline
\end{tabular}




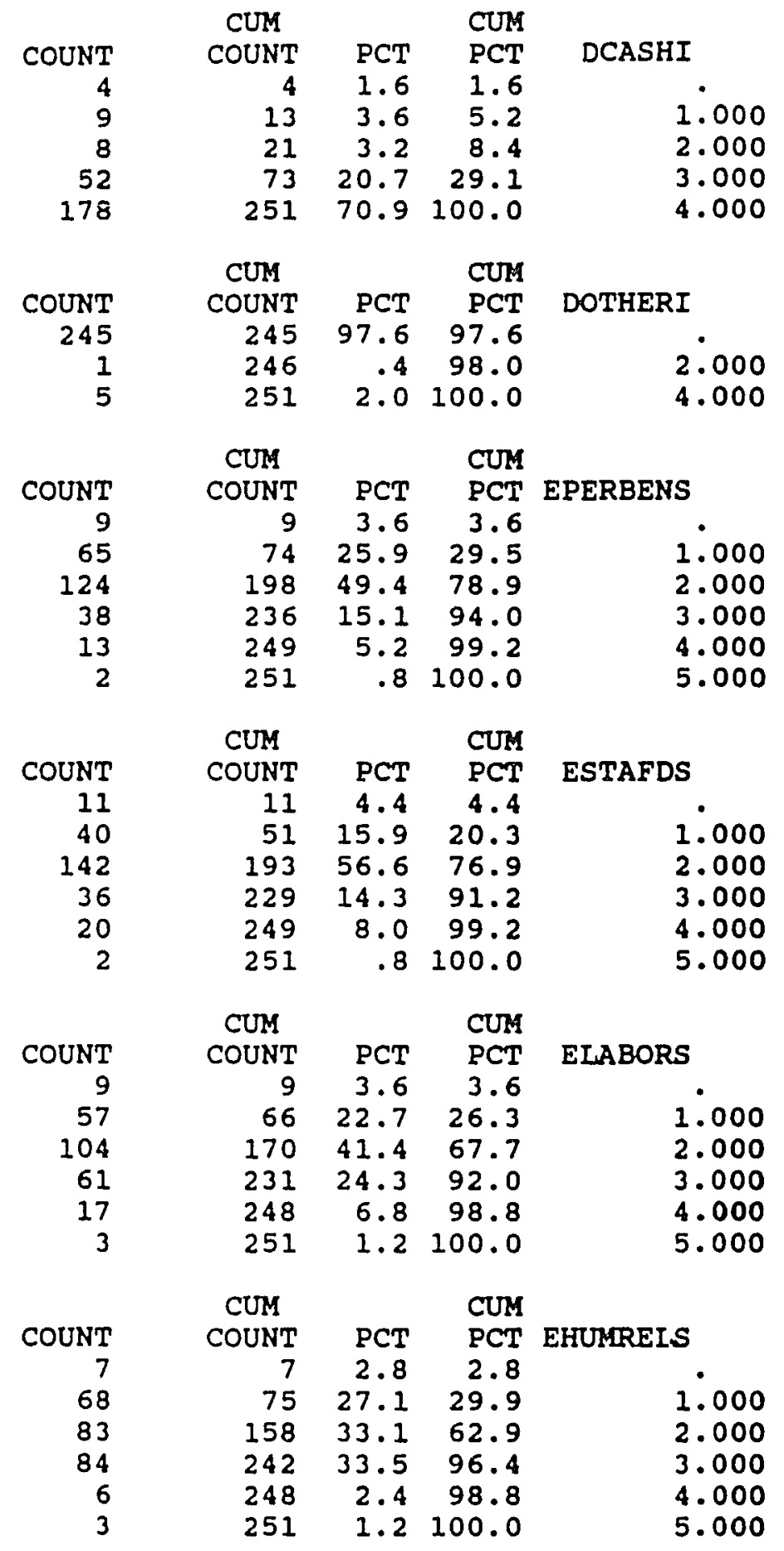




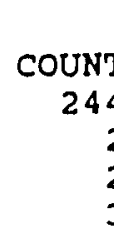

$\begin{array}{rrrr}\text { CUM } & & \text { CUM } & \\ \text { COUNT } & \text { PCT } & \text { PCT } & \text { EOTHERS } \\ 244 & 97.2 & 97.2 & . \\ 246 & .8 & 98.0 & 1.000 \\ 248 & .8 & 98.8 & 2.000 \\ 251 & 1.2 & 100.0 & 3.000\end{array}$

COUNT

$\begin{array}{rrrr}\text { CUM } & & \text { CUM } & \\ \text { COUNT } & \text { PCT } & \text { PCT } & \text { EPERBENI } \\ 5 & 2.0 & 2.0 & . \\ 13 & 3.2 & 5.2 & 1.000 \\ 18 & 2.0 & 7.2 & 2.000 \\ 106 & 35.1 & 42.2 & 3.000 \\ 251 & 57.8 & 100.0 & 4.000\end{array}$

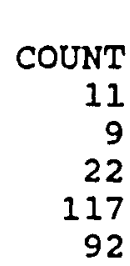

COUNT

CUM
COUN'
11
20
42
159
251

CUM

PCT PCT ESTAFDI

$\begin{array}{lll}4.4 & 4.4\end{array}$

$\begin{array}{lll}3.6 & 8.0 & 1.000\end{array}$

$\begin{array}{lll}8.8 & 16.7 & 2.000\end{array}$

$\begin{array}{lll}46.6 & 63.3 & 3.000\end{array}$

$36.7100 .0 \quad 4.000$

8

$\begin{array}{rrrr}\text { CUM } & & \text { CUM } & \\ \text { COUNT } & \text { PCT } & \text { PCT } & \text { ELABORI } \\ 8 & 3.2 & 3.2 & . \\ 14 & 2.4 & 5.6 & 1.000 \\ 32 & 7.2 & 12.7 & 2.000 \\ 103 & 28.3 & 41.0 & 3.000 \\ 250 & 58.6 & 99.6 & 4.000 \\ 251 & .4 & 100.0 & 9.000\end{array}$

\begin{tabular}{cccc}
\multicolumn{1}{c}{ CUM } & \multicolumn{1}{c}{ CUM } \\
COUNT COUNT & PCT & PCT EHUMRELI
\end{tabular}

$\begin{array}{rrrrr}7 & 7 & 2.8 & 2.8 & 1.000 \\ 7 & 14 & 2.8 & 5.6 & 1.000\end{array}$

$\begin{array}{lllll}12 & 26 & 4.8 & 10.4 & 2.000\end{array}$

$\begin{array}{lllll}79 & 105 & 31.5 & 41.8 & 3.000\end{array}$

$\begin{array}{lllll}146 & 251 & 58.2 & 100.0 & 4.000\end{array}$

\begin{tabular}{rrrrr}
\multicolumn{1}{c}{ CUM } & & CUM & \\
COUNT & COUNT & PCT & PCT & EOTHERI. \\
244 & 244 & 97.2 & 97.2 &. \\
1 & 245 & .4 & 97.6 & 3.000 \\
6 & 251 & 2.4 & 100.0 & 4.000
\end{tabular}

$\begin{array}{rrrrr} & \text { CUM } & & \text { CUM } & \\ \text { COUNT } & \text { COUNT } & \text { PCT } & \text { PCT } & \text { FPLACONS } \\ 10 & 10 & 4.0 & 4.0 & \text {. } \\ 62 & 72 & 24.7 & 28.7 & 1.000 \\ 85 & 157 & 33.9 & 62.5 & 2.000 \\ 68 & 225 & 27.1 & 89.6 & 3.000 \\ 22 & 247 & 8.8 & 98.4 & 4.000 \\ 4 & 251 & 1.6 & 100.0 & 5.000\end{array}$




\begin{tabular}{|c|c|c|c|c|}
\hline \multirow{7}{*}{$\begin{array}{r}\text { COUNT } \\
9 \\
39 \\
97 \\
91 \\
13 \\
2\end{array}$} & CUM & & CUM & \\
\hline & $\begin{array}{r}\text { COUNT } \\
9\end{array}$ & $\begin{array}{l}\text { PCT } \\
3.6\end{array}$ & $\begin{array}{l}\text { PCT } \\
3.6\end{array}$ & FMAINOS \\
\hline & 48 & 15.5 & 19.1 & 1.000 \\
\hline & 145 & 38.6 & 57.8 & 2.000 \\
\hline & 236 & 36.3 & 94.0 & 3.000 \\
\hline & 249 & 5.2 & 99.2 & 4.000 \\
\hline & 251 & .8 & 100.0 & 5.000 \\
\hline \multirow{8}{*}{$\begin{array}{r}\text { COUNT } \\
7 \\
51 \\
105 \\
71 \\
14 \\
3\end{array}$} & CUM & & CUM & \multirow[b]{2}{*}{ FPURCHS } \\
\hline & COUNT & PCT & PCT & \\
\hline & 7 & 2.8 & 2.8 & - \\
\hline & 58 & 20.3 & 23.1 & 1.000 \\
\hline & 163 & 41.8 & 64.9 & 2.000 \\
\hline & 234 & 28.3 & 93.2 & 3.000 \\
\hline & 248 & 5.6 & 98.8 & 4.000 \\
\hline & 251 & 1.2 & 100.0 & 5.000 \\
\hline \multirow[b]{2}{*}{ COUNT } & CUM & & CUM & \multirow[b]{2}{*}{ FSUPEQS } \\
\hline & COUNT & PCT & PCT & \\
\hline 9 & 9 & 3.6 & 3.6 & $\therefore$ \\
\hline \multirow{2}{*}{$\begin{array}{r}27 \\
114\end{array}$} & 36 & 10.8 & 14.3 & \multirow{4}{*}{$\begin{array}{l}1.000 \\
2.000 \\
3.000 \\
4.000\end{array}$} \\
\hline & 150 & 45.4 & 59.8 & \\
\hline 87 & 237 & 34.7 & 94.4 & \\
\hline 10 & 247 & 4.0 & 98.4 & \\
\hline \multirow[t]{2}{*}{4} & 251 & 1.6 & 100.0 & 5.000 \\
\hline & CUM & & CUM & \multirow[b]{2}{*}{ FREALES } \\
\hline \multirow{2}{*}{$\begin{array}{r}\text { COUNT } \\
16\end{array}$} & COUNT & PCT & PCT & \\
\hline & 16 & 6.4 & 6.4 & 正 \\
\hline 30 & 46 & 12.0 & 18.3 & 1.000 \\
\hline 100 & 146 & 39.8 & 58.2 & 2.000 \\
\hline 55 & 201 & 21.9 & 80.1 & 3.000 \\
\hline 23 & 224 & 9.2 & 89.2 & 4.000 \\
\hline \multirow[t]{2}{*}{27} & 251 & 10.8 & 100.0 & 5.000 \\
\hline & CUM & & CUM & \multirow[b]{2}{*}{ FOTHERS } \\
\hline $\begin{array}{r}\text { COUNT } \\
248\end{array}$ & COUNT & PCT & PCT & \\
\hline 248 & 248 & 98.8 & 98.8 & 90 \\
\hline 1 & 249 & .4 & 99.2 & 1.000 \\
\hline 1 & 250 & .4 & 99.6 & 2.000 \\
\hline \multirow[t]{2}{*}{1} & 251 & .4 & 100.0 & 3.000 \\
\hline & CUM & & CUM & \\
\hline COUNT & COUNT & PCT & PCT & FPLACONI \\
\hline 10 & 10 & 4.0 & 4.0 & - \\
\hline 6 & 16 & 2.4 & 6.4 & 1.000 \\
\hline 17 & 33 & 6.8 & 13.1 & 2.000 \\
\hline 101 & 134 & 40.2 & 53.4 & 3.000 \\
\hline 117 & 251 & 46.6 & 100.0 & 4.000 \\
\hline
\end{tabular}




\begin{tabular}{|c|c|c|c|c|}
\hline \multirow{7}{*}{$\begin{array}{r}\text { COUNT } \\
10 \\
8 \\
10 \\
94 \\
129\end{array}$} & CUM & & CUM & \multirow[b]{2}{*}{ FMAINOI } \\
\hline & COUNT & PCT & PCT & \\
\hline & 10 & 4.0 & 4.0 & • \\
\hline & 18 & 3.2 & 7.2 & 1.000 \\
\hline & 28 & 4.0 & 11.2 & 2.000 \\
\hline & 122 & 37.5 & 48.6 & 3.000 \\
\hline & 251 & 51.4 & 100.0 & 4.000 \\
\hline \multirow[b]{2}{*}{ COUNT } & \multicolumn{2}{|l|}{ CUM } & \multirow[t]{2}{*}{ CUM } & \multirow[b]{2}{*}{ FPURCHI } \\
\hline & COUNT & PCT & & \\
\hline \multirow{6}{*}{$\begin{array}{r}8 \\
5 \\
7 \\
94 \\
137\end{array}$} & 8 & 3.2 & 3.2 & \\
\hline & 13 & 2.0 & 5.2 & \multirow{4}{*}{$\begin{array}{l}1.000 \\
2.000 \\
3.000 \\
4.000\end{array}$} \\
\hline & 20 & 2.8 & 8.0 & \\
\hline & 114 & 37.5 & 45.4 & \\
\hline & 251 & 54.6 & 100.0 & \\
\hline & \multicolumn{2}{|l|}{ CUM } & CUM & \multirow[b]{2}{*}{ FSIPFOT } \\
\hline \multirow{2}{*}{$\begin{array}{r}\text { COUNT } \\
10\end{array}$} & COUNT & PCT & PCT & \\
\hline & 10 & 4.0 & 4.0 & \multirow{2}{*}{$\therefore$} \\
\hline \multirow{2}{*}{$\begin{array}{r}5 \\
27\end{array}$} & 15 & 2.0 & 6.0 & \\
\hline & 42 & 10.8 & 16.7 & 2.000 \\
\hline \multirow{2}{*}{$\begin{array}{r}115 \\
94\end{array}$} & 157 & 45.8 & 62.5 & 3.000 \\
\hline & 251 & 37.5 & 100.0 & 4.000 \\
\hline \multirow{7}{*}{$\begin{array}{r}\text { COUNT } \\
27 \\
14 \\
65 \\
98 \\
47\end{array}$} & \multicolumn{2}{|l|}{ CUM } & CUM & \\
\hline & COUNT & PCT & PCT & FREALEI \\
\hline & 27 & 10.8 & 10.8 & \\
\hline & 41 & 5.6 & 16.3 & 1.000 \\
\hline & 106 & 25.9 & 42.2 & 2.000 \\
\hline & 204 & 39.0 & 81.3 & 3.000 \\
\hline & 251 & 18.7 & 100.0 & 4.000 \\
\hline \multirow[b]{2}{*}{ COUNT } & CUM & & CUM & \\
\hline & COUNT & PCT & PCT & FOTHERI \\
\hline \multirow{2}{*}{$\begin{array}{r}248 \\
1\end{array}$} & 248 & 98.8 & 98.8 & - \\
\hline & 249 & .4 & 99.2 & 1.000 \\
\hline \multirow{3}{*}{1} & 250 & .4 & 99.6 & 2.000 \\
\hline & 251 & .4 & 100.0 & 4.000 \\
\hline & CUM & & CUM & \\
\hline COUNT & COUNT & PCT & PCT & GSTRPLNS \\
\hline 9 & 9 & 3.6 & 3.6 & • \\
\hline 74 & 83 & 29.5 & 33.1 & 1.000 \\
\hline 120 & 203 & 47.8 & 80.9 & 2.000 \\
\hline 37 & 240 & 14.7 & 95.6 & 3.000 \\
\hline 8 & 248 & 3.2 & 98.8 & 4.000 \\
\hline 3 & 251 & 1.2 & 100.0 & 5.000 \\
\hline
\end{tabular}




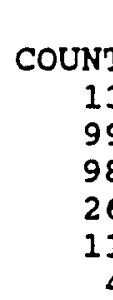

$\begin{array}{rrrr}\text { CUM } & & \text { CUM } & \\ \text { COUNT } & \text { PCT } & \text { PCT } & \text { GEVALRES } \\ 13 & 5.2 & 5.2 & . \\ 112 & 39.4 & 44.6 & 1.000 \\ 210 & 39.0 & 83.7 & 2.000 \\ 236 & 10.4 & 94.0 & 3.000 \\ 247 & 4.4 & 98.4 & 4.000 \\ 251 & 1.6 & 100.0 & 5.000\end{array}$

COUNT

9
70

87

69

14

2

COUNT

8
84

101

36

20

2

CUM
COUNT
9

CUS

PCT PCT

$\begin{array}{rr}3.6 & 3.6\end{array}$

GCOMMS

$\begin{array}{rrr}79 & 27.9 & 31.5 \\ 166 & 34.7 & 66.1\end{array}$

$\begin{array}{lll}235 & 27.5 & 93.6\end{array}$

$\begin{array}{lll}249 & 5.6 & 99.2\end{array}$

251

.8100 .0

1.000

2.000

3.000

4.000

5.000

\begin{tabular}{rrrr} 
CUM & & CUM & \multicolumn{1}{c}{ GMISS } \\
COUNT & PCT & PCT & \multicolumn{1}{l}{} \\
8 & 3.2 & 3.2 & 0 \\
92 & 33.5 & 36.7 & 1.000 \\
193 & 40.2 & 76.9 & 2.000 \\
229 & 14.3 & 91.2 & 3.000 \\
249 & 8.0 & 99.2 & 4.000 \\
251 & .8 & 100.0 & 5.000
\end{tabular}

COUNT
245
1
3
1

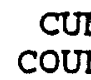

CUM CUM

245

PCT PCT

GOTHERS

246

249

$97.6 \quad 97.6$

.498 .0

1.299 .2

$.4 \quad 99.6$

.4100 .0

1.000

2.000

3.000

251

\section{CUR}

COUNT

10

13

20

73

135

CUM
COUNT
10
23
43
116

PCT PCT

4.04 .0

$5.2 \quad 9.2$

$8.0 \quad 17.1$

$29.1 \quad 46.2$

251

$53.8 \quad 100.0$

4.000

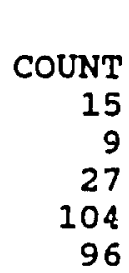

\begin{tabular}{|c|c|c|c|c|}
\hline & CUM & & CUM & \\
\hline IN" & COUNT & $\mathrm{PCT}$ & $\mathrm{PCT}$ & GEVALREI \\
\hline 15 & 15 & 6.0 & 6.0 & • \\
\hline & 24 & 3.6 & 9.6 & 1.000 \\
\hline & 51 & 10.8 & 20.3 & 2.000 \\
\hline & 155 & 41.4 & 61.8 & 3.000 \\
\hline
\end{tabular}

GEVALREI 


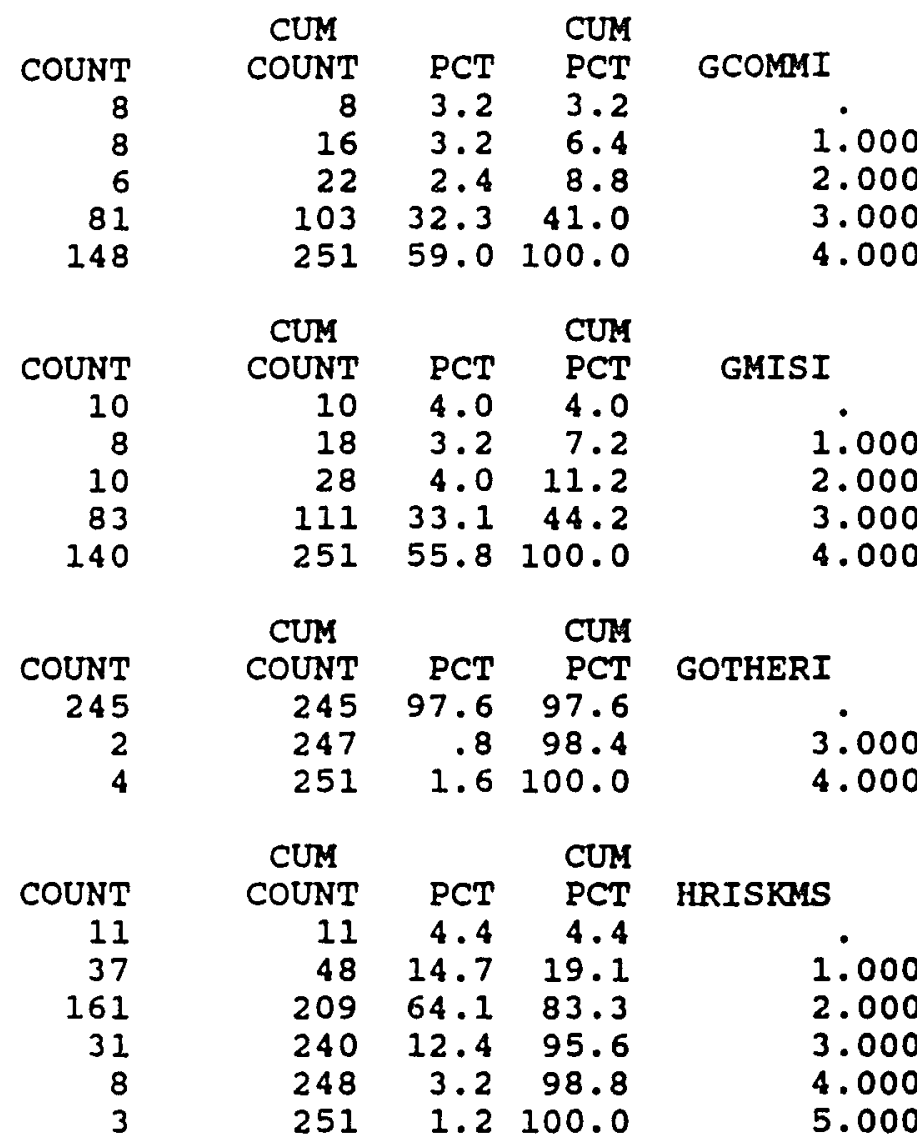

COUNT

CUM CUM

COUNT PCT PCT HTRANSPS

$\begin{array}{rrrrr}8 & 8 & 3.2 & 3.2 & \\ 22 & 30 & 8.8 & 12.0 & 1.000 \\ 121 & 151 & 48.2 & 60.2 & 2.000 \\ 81 & 232 & 32.3 & 92.4 & 3.000 \\ 15 & 247 & 6.0 & 98.4 & 4.000 \\ 4 & 251 & 1.6 & 100.0 & 5.000\end{array}$

\begin{tabular}{rrrrr}
\multicolumn{1}{c}{ CUM } & & CUM & \\
COUNT & COUNT & PCT & PCT & HFOODSRS \\
12 & 12 & 4.8 & 4.8 & .000 \\
31 & 43 & 12.4 & 17.1 & 1.000 \\
121 & 164 & 48.2 & 65.3 & 2.000 \\
68 & 232 & 27.1 & 92.4 & 3.000 \\
13 & 245 & 5.2 & 97.6 & 4.000 \\
6 & 251 & 2.4 & 100.0 & 5.000
\end{tabular}




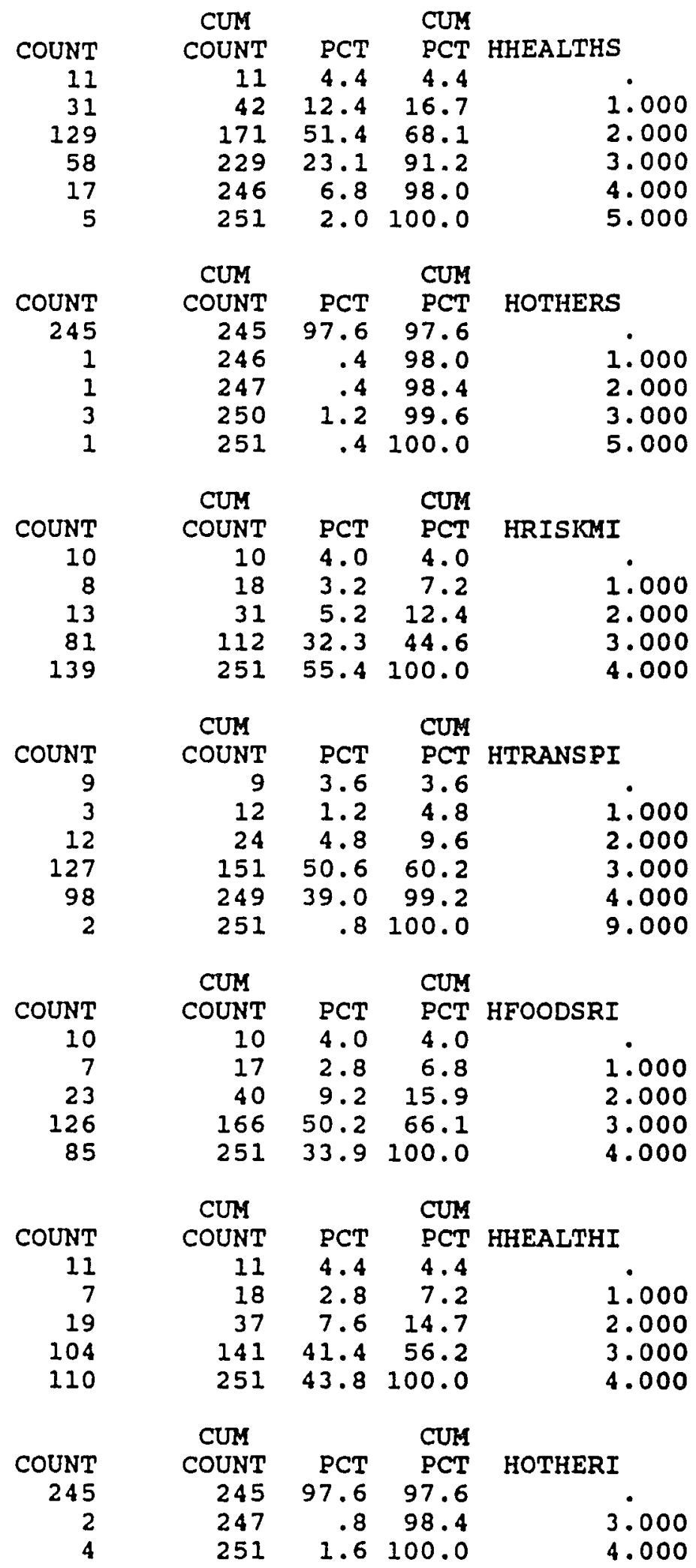




\begin{tabular}{|c|c|c|c|c|}
\hline \multirow{6}{*}{$\begin{array}{r}\text { COUNT } \\
242 \\
1 \\
6 \\
2\end{array}$} & CUM & & CUM & \\
\hline & COUNT & PCT & PCT & IOTHERS \\
\hline & 242 & 96.4 & 96.4 & $\bullet$ \\
\hline & 243 & .4 & 96.8 & 1.000 \\
\hline & 249 & 2.4 & 99.2 & 2.000 \\
\hline & 251 & .8 & 100.0 & 3.000 \\
\hline \multirow{4}{*}{$\begin{array}{r}\text { COUNT } \\
242 \\
9\end{array}$} & CUM & & CUM & \\
\hline & COUNT & PCT & PCT & IOTHERI \\
\hline & 242 & 96.4 & 96.4 & - \\
\hline & 251 & 3.6 & 100.0 & 4.000 \\
\hline \multirow{7}{*}{$\begin{array}{r}\text { COUNT } \\
4 \\
45 \\
101 \\
81 \\
20\end{array}$} & CUM & & CUM & \\
\hline & COUNT & PCT & РCT & JAGE \\
\hline & & 1.6 & 1.6 & 1.000 \\
\hline & 49 & 17.9 & 19.5 & 2.000 \\
\hline & 150 & 40.2 & 59.8 & 3.000 \\
\hline & 231 & 32.3 & 92.0 & 4.000 \\
\hline & 251 & 8.0 & 100.0 & 5.000 \\
\hline \multirow{5}{*}{$\begin{array}{r}\text { COUNT } \\
1 \\
57 \\
193\end{array}$} & CUM & & CUM & \\
\hline & COUNT & PCT & PCT & JGENDER \\
\hline & 1 & .4 & .4 & • \\
\hline & 58 & 22.7 & 23.1 & 1.000 \\
\hline & 251 & 76.9 & 100.0 & 2.000 \\
\hline \multirow{7}{*}{$\begin{array}{r}\text { COUNT } \\
16 \\
48 \\
35 \\
87 \\
65\end{array}$} & CUM & & CUM & \\
\hline & COUNT & PCT & PCT & JLOCAT \\
\hline & 16 & 6.4 & 6.4 & 1.000 \\
\hline & 64 & 19.1 & 25.5 & 2.000 \\
\hline & 99 & 13.9 & 39.4 & 3.000 \\
\hline & 186 & 34.7 & 74.1 & 4.000 \\
\hline & 251 & 25.9 & 100.0 & 5.000 \\
\hline \multirow{6}{*}{$\begin{array}{r}\text { COUNT } \\
18 \\
152 \\
46 \\
35\end{array}$} & CUM & & CUM & \\
\hline & COUNT & PCT & PCT & JRESP \\
\hline & 18 & 7.2 & 7.2 & $\theta^{\circ}$ \\
\hline & 170 & 60.6 & 67.7 & 1.000 \\
\hline & 216 & 18.3 & 86.1 & 2.000 \\
\hline & 251 & 13.9 & 100.0 & 3.000 \\
\hline \multirow{6}{*}{$\begin{array}{r}\text { COUNT } \\
22 \\
43 \\
59 \\
127\end{array}$} & CUM & & CUM & \\
\hline & COUNT & PCT & РCT & JEXP \\
\hline & 22 & 8.8 & 8.8 & • \\
\hline & 65 & 17.1 & 25.9 & 1.000 \\
\hline & 124 & 23.5 & 49.4 & 2.000 \\
\hline & 251 & 50.6 & 100.0 & 3.000 \\
\hline \multirow{6}{*}{$\begin{array}{r}\text { COUNT } \\
24 \\
73 \\
101 \\
53\end{array}$} & CUM & & CUM & \\
\hline & COUNT & PCT & PCT & JBUDG \\
\hline & 24 & 9.6 & 9.6 & \\
\hline & 97 & 29.1 & 38.6 & 1.000 \\
\hline & 198 & 40.2 & 78.9 & 2.000 \\
\hline & 251 & 21.1 & 100.0 & 3.000 \\
\hline
\end{tabular}




$\begin{array}{rrrrc}\text { COUNT } & \text { CUM } & & \text { CUM } & \\ 25 & \text { COUNT } & \text { PCT } & \text { PCT } & \text { JTYPE } \\ 48 & 25 & 10.0 & 10.0 & .000 \\ 82 & 73 & 19.1 & 29.1 & 1.000 \\ 96 & 155 & 32.7 & 61.8 & 2.000 \\ & 251 & 38.2 & 100.0 & 3.000 \\ \text { COUNT } & \text { CUM } & & \text { CUM } & \\ 21 & \text { COUNT } & \text { PCT } & \text { PCT } & \text { JEDUC } \\ 23 & 21 & 8.4 & 8.4 & . \\ 63 & 44 & 9.2 & 17.5 & 1.000 \\ 144 & 107 & 25.1 & 42.6 & 2.000 \\ & 251 & 57.4 & 100.0 & 3.000 \\ \text { COUNT } & \text { CUM } & & \text { CUM } & \\ 214 & 214 & 85.3 & 85.3 & \\ 4 & 218 & 1.6 & 86.9 & 1.000 \\ 11 & 229 & 4.4 & 91.2 & 2.000 \\ 3 & 232 & 1.2 & 92.4 & 3.000 \\ 19 & 251 & 7.6 & 100.0 & 4.000\end{array}$

